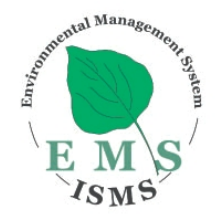

\title{
Site Environmental Report for 2011 Sandia National Laboratories, California
}

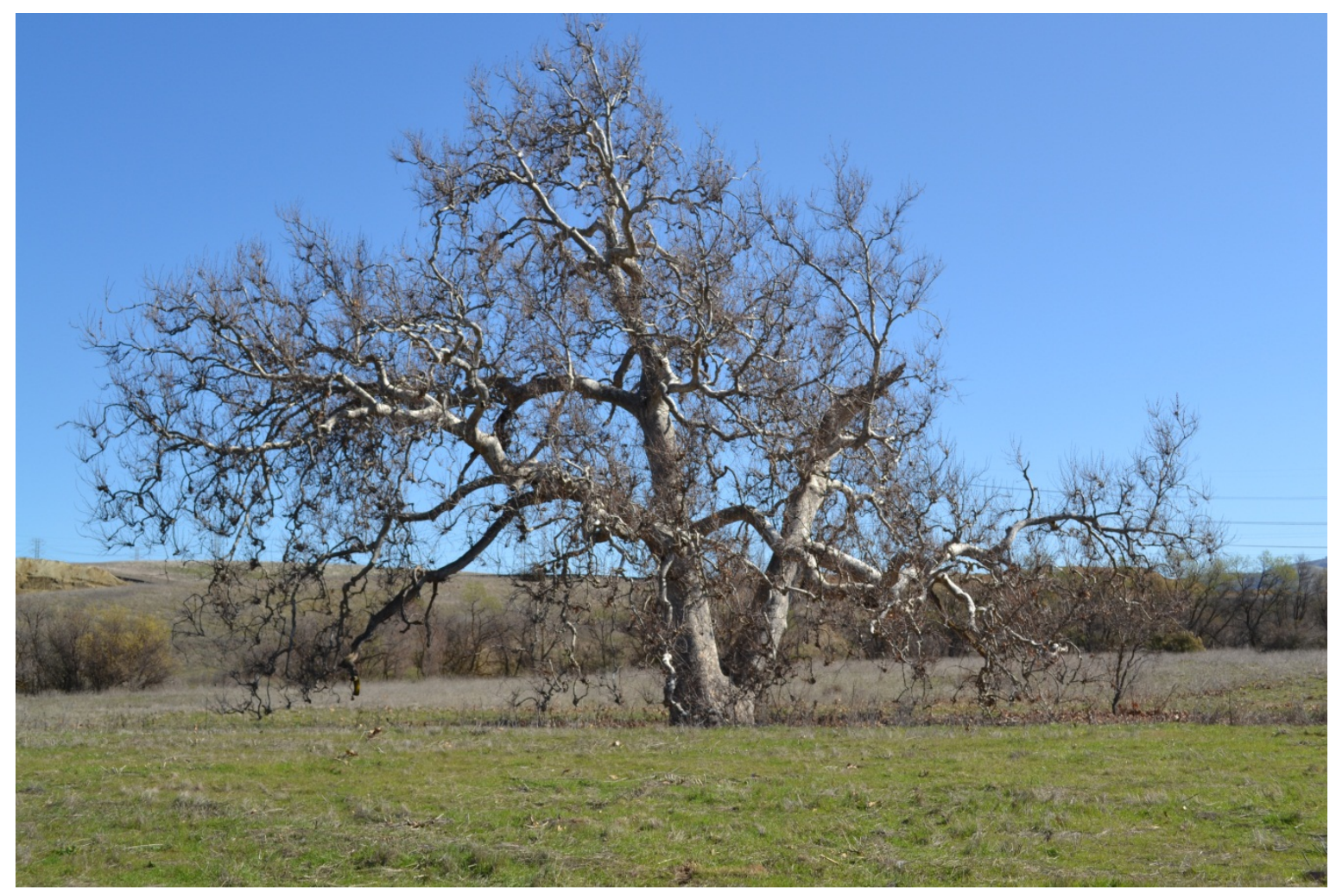

\section{B.L. Larsen}

Prepared by

Sandia National Laboratories

Livermore, California 94550

Sandia National Laboratories is a multi-program laboratory managed and operated by Sandia Corporation, a wholly owned subsidiary of Lockheed Martin Corporation, for the U.S. Department of Energy's National Nuclear Security Administration under Contract DE-AC04-94AL85000.

Approved for public release, further dissemination unlimited.

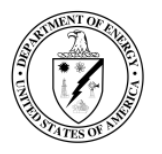


Issued by Sandia National Laboratories, managed and operated for the United States Department of Energy by Sandia Corporation.

NOTICE: This report was prepared as an account of work sponsored by an agency of the United States Government. Neither the United States Government, nor any agency thereof, nor any of their employees, nor any of their contractors, subcontractors, or their employees, make any warranty, express or implied, or assume any legal liability or responsibility for the accuracy, completeness, or usefulness of any information, apparatus, product, or process disclosed, or represent that its use would not infringe privately owned rights. Reference herein to any specific commercial product, process, or service by trade name, trademark, manufacturer, or otherwise, does not necessarily constitute or imply its endorsement, recommendation, or favoring by the United States Government, any agency thereof, or any of their contractors or subcontractors. The views and opinions expressed herein do not necessarily state or reflect those of the United States Government, any agency thereof, or any of their contractors.

Printed in the United States of America. This report has been reproduced directly from the best available copy.

Available to DOE and DOE contractors from

U.S. Department of Energy

Office of Scientific and Technical Information

P.O. Box 62

Oak Ridge, TN 37831

Telephone: $\quad$ (865) 576-8401

Facsimile: $\quad$ (865) 576-5728

E-Mail: $\quad$ reports@adonis.osti.gov

Online ordering: http://www.doe.gov/bridge

Available to the public from

U.S. Department of Commerce

National Technical Information Service

5285 Port Royal Road

Springfield, VA 22161

Telephone: (800) 553-6847

Facsimile: (703) 605-6900

E-Mail:_orders@ntis.fedworld.gov

Online order: http://www.ntis.gov/ordering.htm

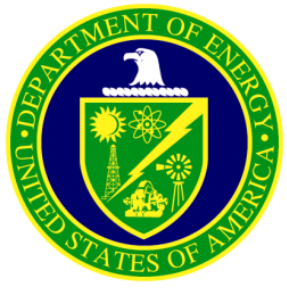




\title{
Site Environmental Report for 2011 Sandia National Laboratories, California
}

\author{
Barbara L. Larsen \\ Environmental Management Department \\ Sandia National Laboratories, California \\ 7011 East Avenue \\ Livermore, CA 94550
}

\begin{abstract}
Sandia National Laboratories, California (SNL/CA) is a government-owned/contractoroperated laboratory. Sandia Corporation, a wholly-owned subsidiary of Lockheed Martin Corporation, manages and operates the laboratory for the Department of Energy's National Nuclear Security Administration (NNSA). The NNSA Sandia Site Office administers the contract and oversees contractor operations at the site. This Site Environmental Report for 2011 was prepared in accordance with DOE Order 231.1B, Environment, Safety and Health Reporting (DOE 2011d). The report provides a summary of environmental monitoring information and compliance activities that occurred at SNL/CA during calendar year 2011. General site and environmental program information is also included.
\end{abstract}




\title{
Acknowledgements
}

This report was prepared by the Sandia National Laboratories, California Environmental Management Department, and reviewed and approved by the Department of Energy, National Nuclear Security Administration, Sandia Site Office. The author acknowledges the following key contributors to the content, review, and production of this report.

\author{
Karen Agogino \\ Amy Blumberg \\ Mark Brynildson \\ Deanna Dicker \\ Leslee Gardizi \\ Janet Harris \\ Robert Holland \\ Gary Shamber \\ Laura Tidwell
}

Additional information about this report can be obtained from:

\author{
Sandia National Laboratories, California \\ Public and Media Relations Office \\ P.O. Box 969 \\ Livermore, CA 94551-0969 \\ Attention: Mike Janes \\ Phone: (925) 294-2447 \\ E-mail: mejanes@sandia.gov \\ Or \\ U.S. Department of Energy \\ National Nuclear Security Administration \\ Sandia Site Office \\ P.O. Box 5400 \\ Albuquerque, NM 87185-5400 \\ Attention: Karen Agogino \\ Phone: (505) 845-6100 \\ E-mail: Karen.Agogino@nnsa.doe.gov
}




\section{Contents}

1 EXECUTIVE SUMMARY

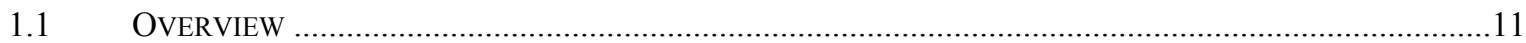

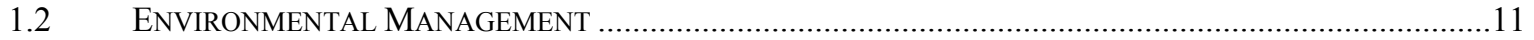

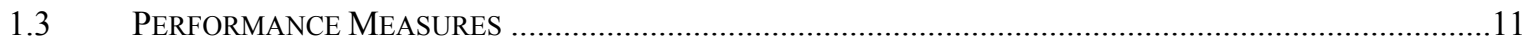

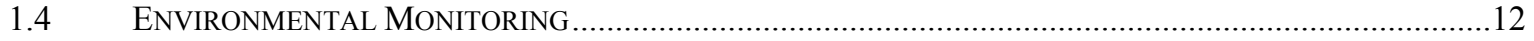

2 INTRODUCTION .............................................................................................................................13

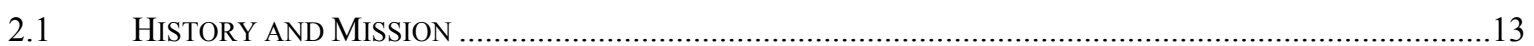

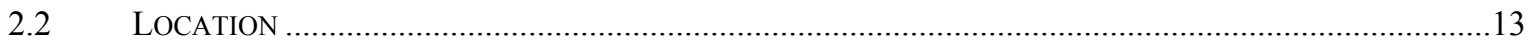

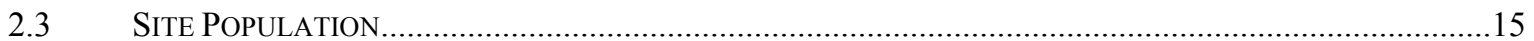

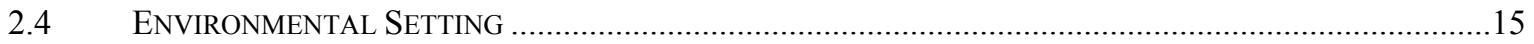

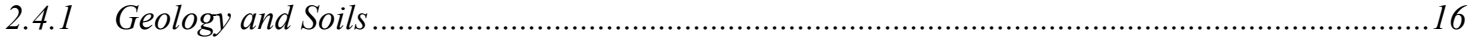

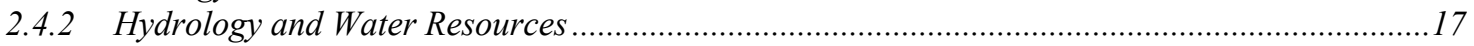

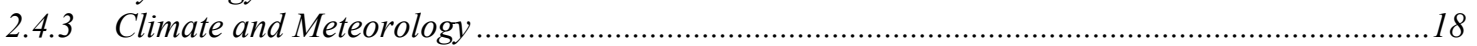

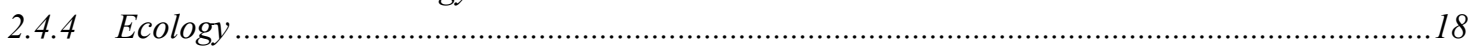

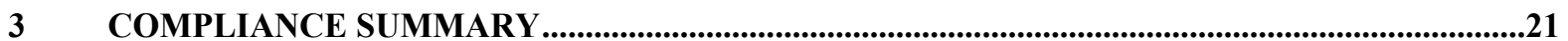

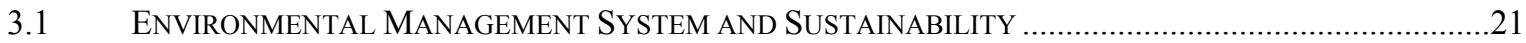

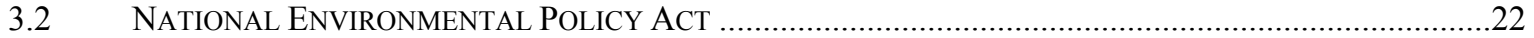

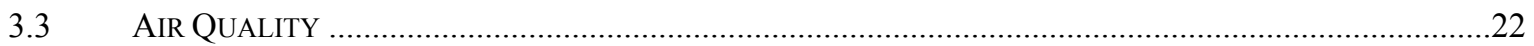

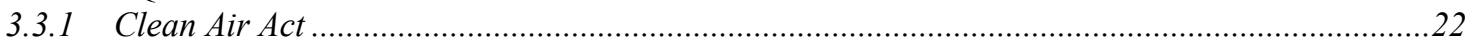

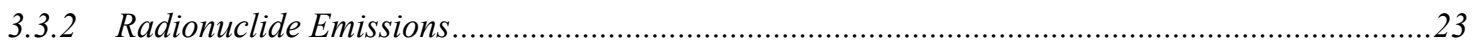

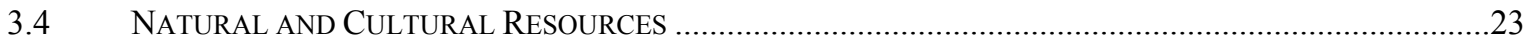

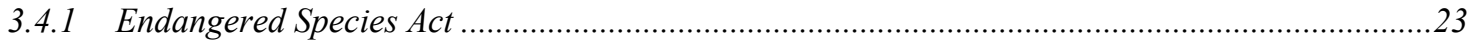

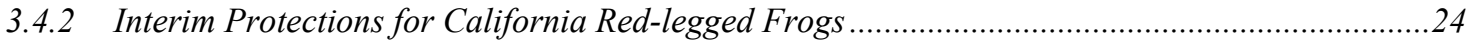

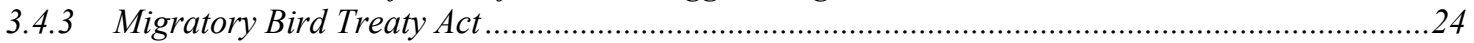

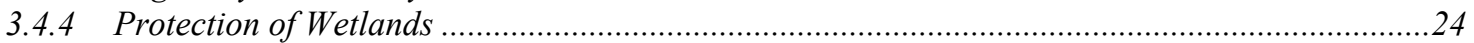

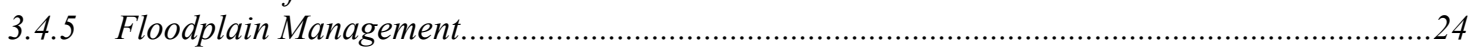

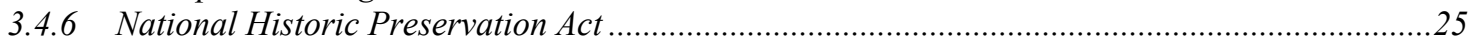

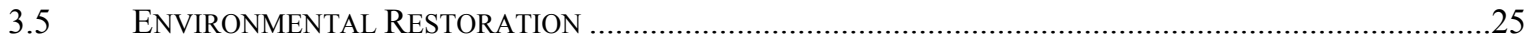

3.5.1 Comprehensive Environmental Response, Compensation, and Liability Act..............................25

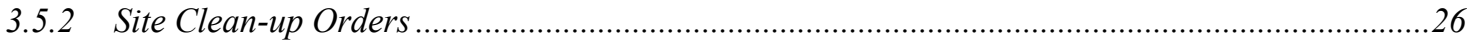

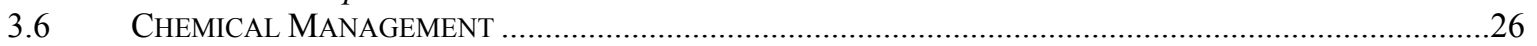

3.6.1 Emergency Planning and Community Right-to-Know Act ....................................................26

3.6.2 California Hazardous Materials Release Response Plans and Inventory Law..........................27

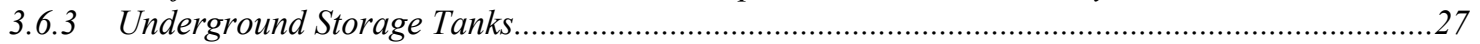

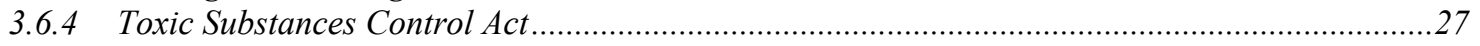

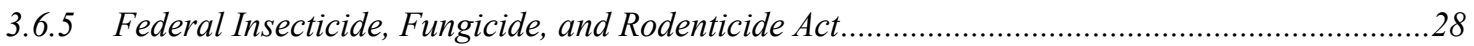

3.7 POLLUTION PREVENTION AND WASTE MINIMIZATION ..............................................................28

3.7.1 Pollution Prevention Goals of Site Sustainability Plan ..............................................................29

3.7.2 Hazardous Waste Source Reduction and Management Review Act ............................................29

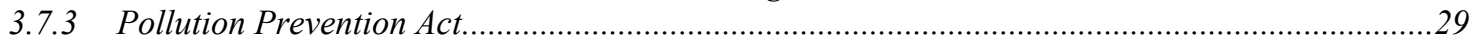

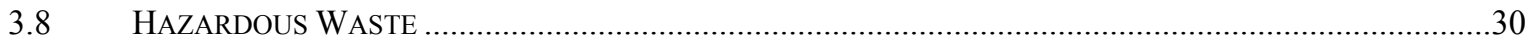

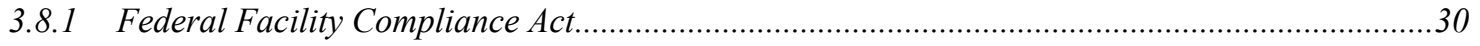

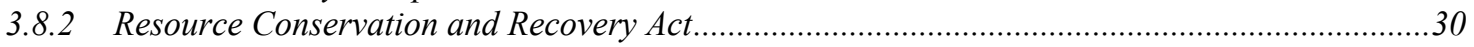

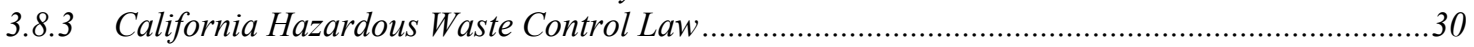

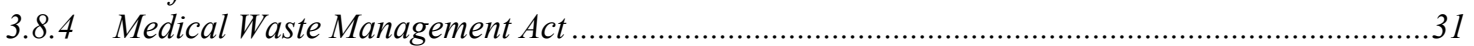

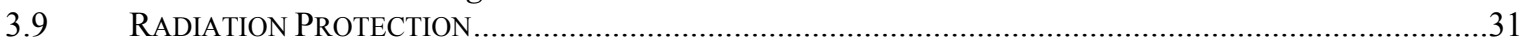

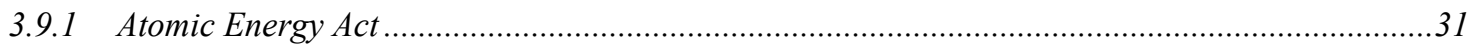

3.9.2 DOE Order 435.1, Radioactive Waste Management .................................................................

3.9.3 DOE Order 458.1, Radiation Protection of the Public and the Environment ...............................32

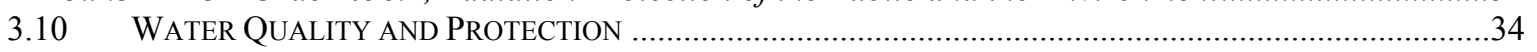

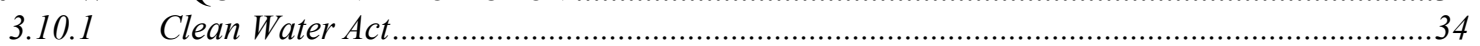




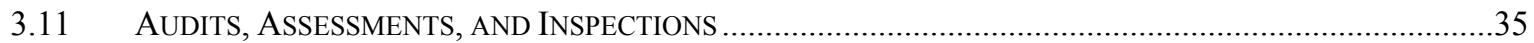

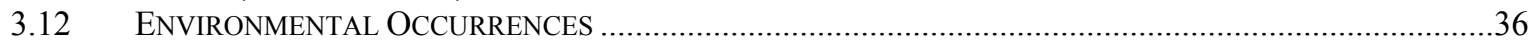

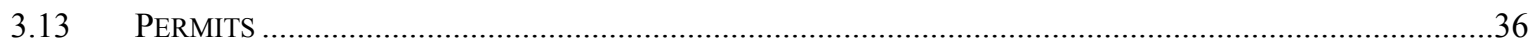

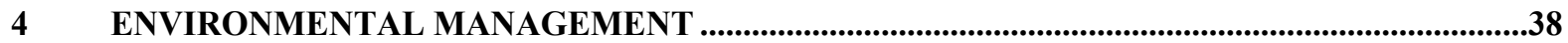

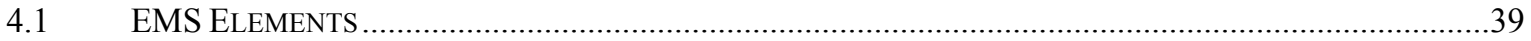

4.2 ENVIRONMENTAL PERFORMANCE ................................................................................................

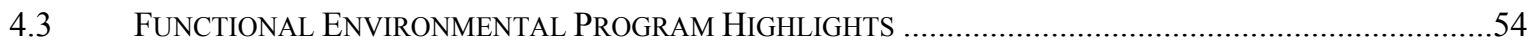

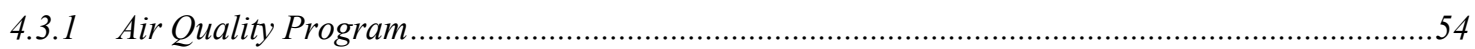

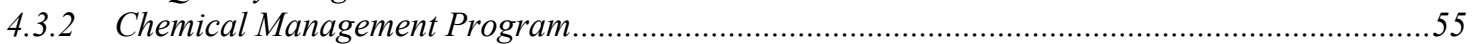

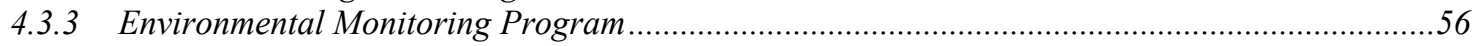

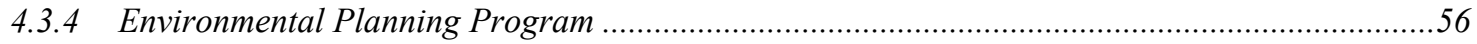

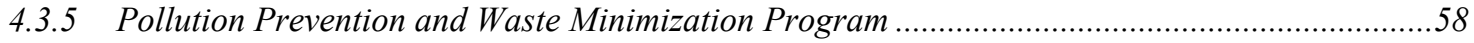

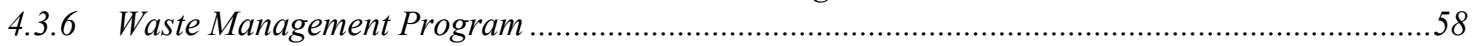

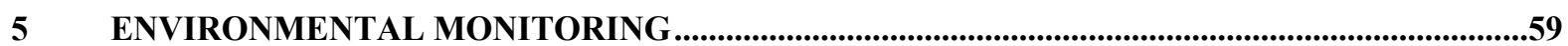

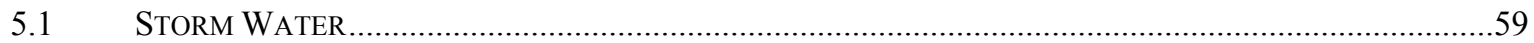

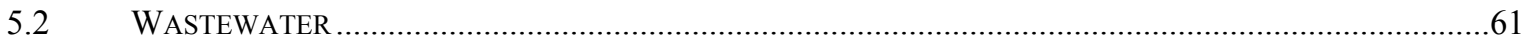

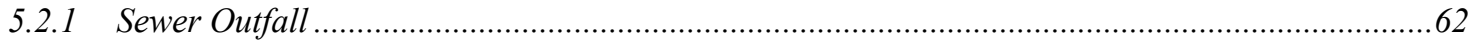

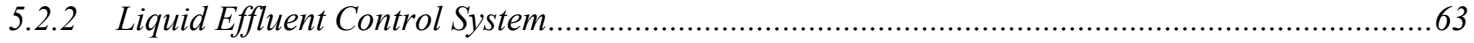

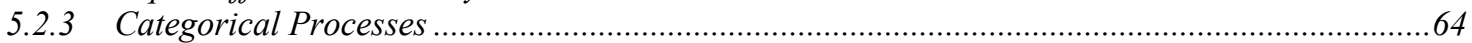

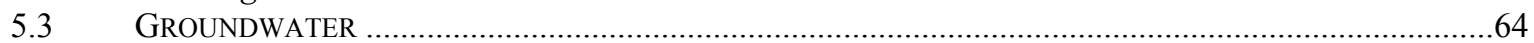

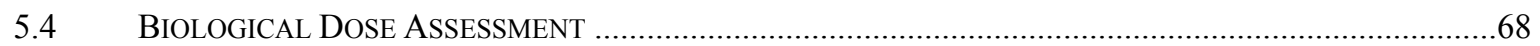

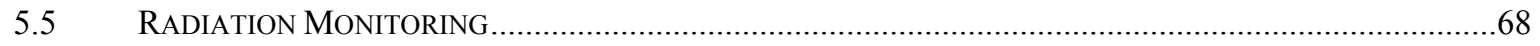

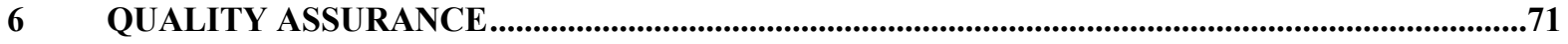

6.1 ENVIRONMENTAL MONITORING QUALITY ASSURANCE ...............................................................71

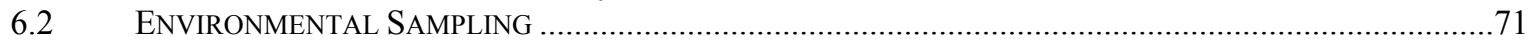

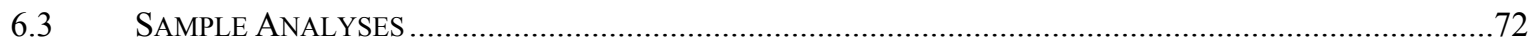

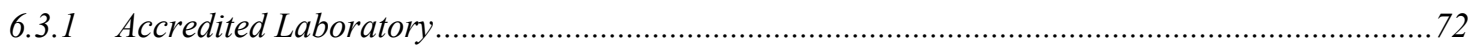

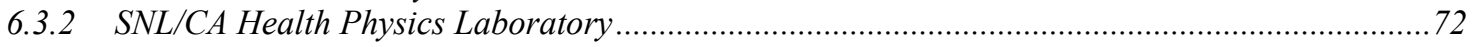

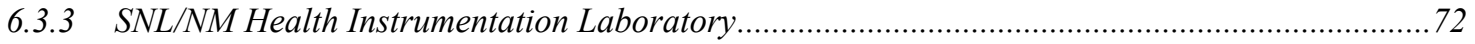

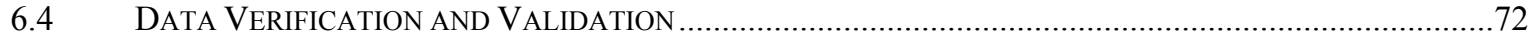

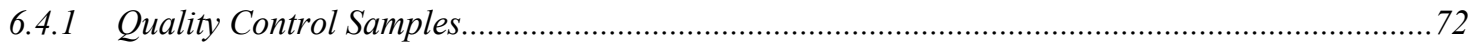

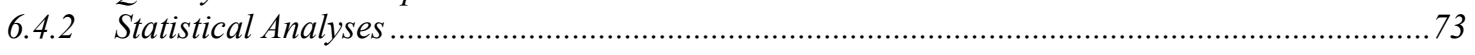

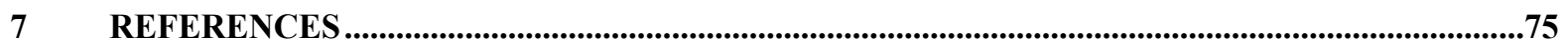

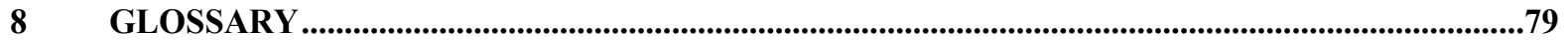

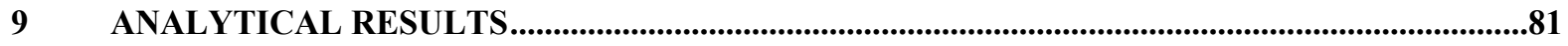

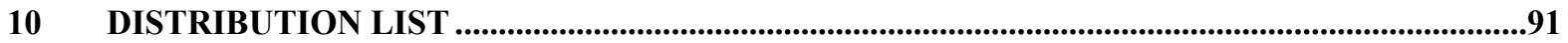




\section{Tables}

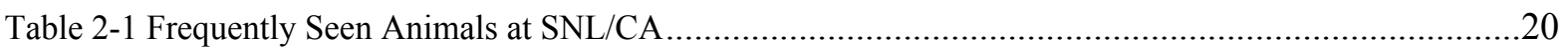

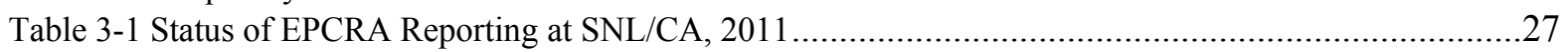

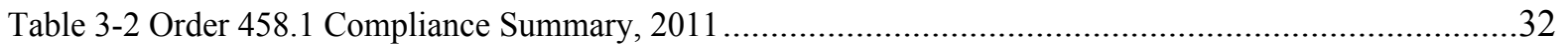

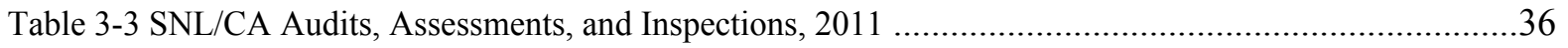

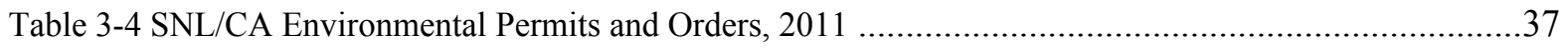

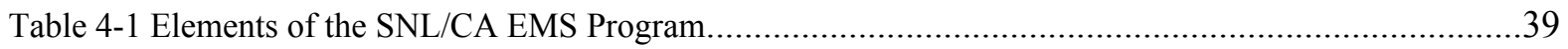

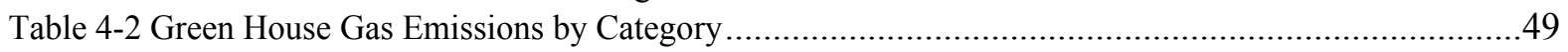

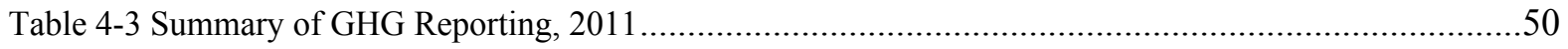

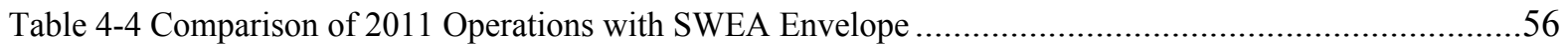

Table 5-1 Summary of Analytical Results for Storm Water, 2010/2011 Wet Season ...................................61

Table 5-2 Sewer Outfall Sampling Schedule, 2011 ...............................................................................62

Table 5-3 Weekly Composite Sewer Outfall Monitoring Results - Physical Parameters and Metals, 2011 .......63

Table 5-4 Monitoring for Semiconductor Manufacturing Categorical Process, 2011 ..................................64

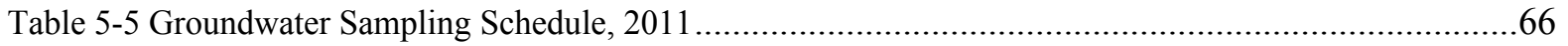

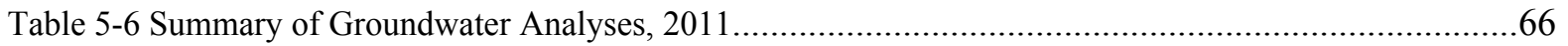

Table 5-7 Summary of Groundwater Analyses at Arroyo Seco Wells, 2011 ............................................67

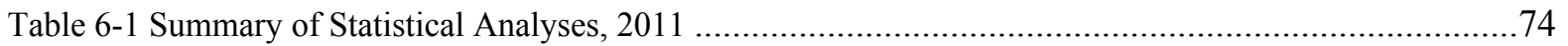

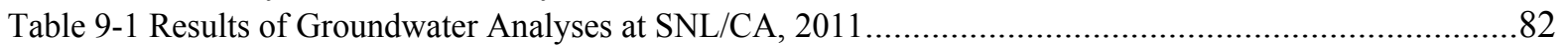

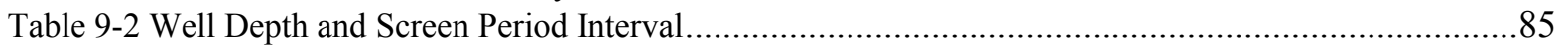

Table 9-3 Routine Monitoring Results for SNL/CA Sanitary Sewer Outfall, 2011 .......................................86

Table 9-4 Routine Monitoring Results for SNL/CA Sanitary Sewer Outfall, Method E200.8, 2011 ..............87

Table 9-5 Routine Monitoring Results for SNL/CA Sanitary Sewer Outfall, 2011 ......................................90

\section{Figures}

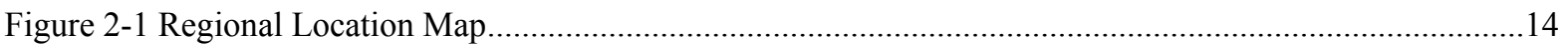

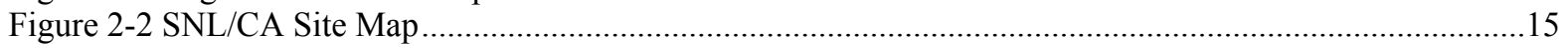

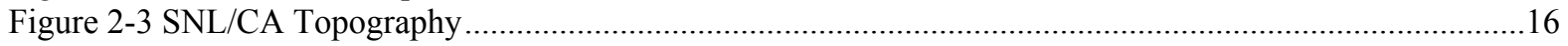

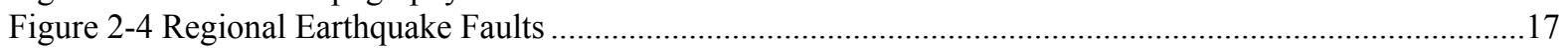

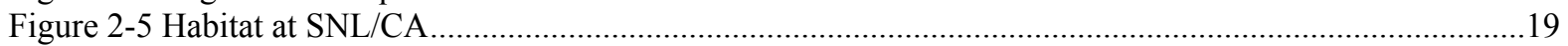

Figure 4-1 Measurement of Excellence in Environmental Management ……...................................................42

Figure 4-2 SNL/CA Hazardous Material Inventory .........................................................................................

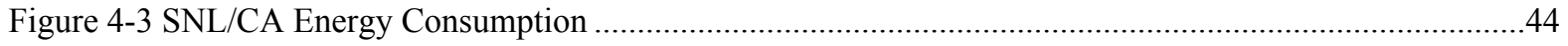

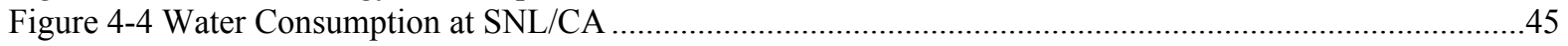

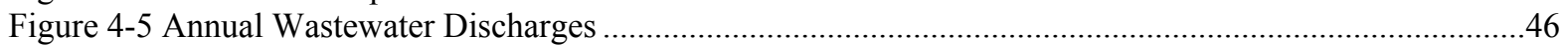

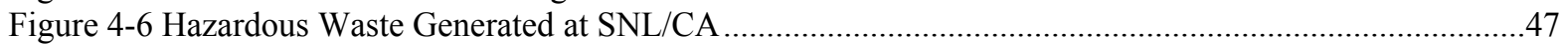

Figure 4-7 Radioactive Waste Generated at SNL/CA ......................................................................................

Figure 4-8 Solid Waste and Construction Debris Diverted From Landfill Disposal ........................................48

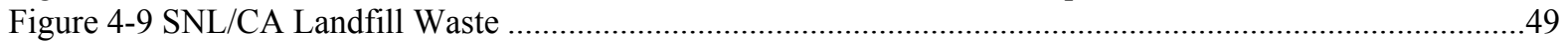

Figure 4-10 Weekly Composite Copper Concentrations in Wastewater.............................................................51

Figure 4-11 Weekly Composite Zinc Concentrations in Wastewater ..................................................................52

Figure 4-12 Constituents in Storm Water, 2010/2011 Rainy Season .............................................................53

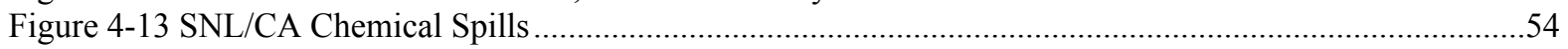

Figure 5-1 Storm Water Sampling Locations .......................................................................................60

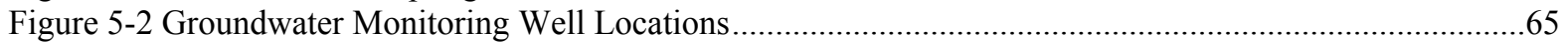

Figure 5-3 Dosimeter Locations at SNL/CA and Around Site Perimeter .........................................................69

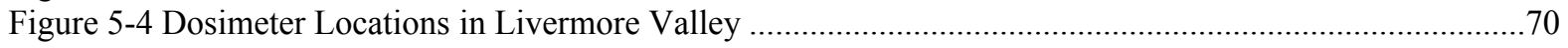




\section{Preface}

Each year, the Sandia National Laboratories, California (SNL/CA), Environmental Management Department prepares a summary report to provide environmental information to the local community, pursuant to the requirements of Department of Energy Order 231.1B, Environment, Safety and Health Reporting. The Site Environmental Report for 2011 summarizes SNL/CA's compliance with environmental requirements, presents the results of monitoring and surveillance activities, and provides an update of site environmental programs.

The Site Environmental Report for 2011 was prepared for ease in readability. Each chapter focuses on a specific topic or area. Reference to other sections and chapters is made throughout the report to avoid redundancy. Detailed data is provided only when necessary to improve the presentation of information and the quality of the document. Acronyms are defined within each chapter as well as listed at the beginning of the report. References are compiled into one list and presented in Chapter 7. 


\title{
Acronyms and Abbreviations
}

\author{
ALARA as low as reasonably achievable \\ BAAQMD Bay Area Air Quality Management District \\ CCR California Code of Regulations \\ CARB California Air Resources Board \\ CEARP Comprehensive Environmental Assessment and Response Program \\ CERCLA Comprehensive Environmental Response, Compensation, and Liability Act \\ CFR Code of Federal Regulations \\ DHS Department of Homeland Security \\ DOE Department of Energy \\ DTSC Department of Toxic Substances Control (California) \\ EMS environmental management system \\ EO executive order \\ EPA Environmental Protection Agency \\ EPCRA Emergency Planning and Community Right-to-Know Act \\ ES\&H environment, safety, and health \\ FIFRA Federal Insecticide, Fungicide, and Rodenticide Act \\ FONSI Finding of No Significant Impact \\ General State of California, NPDES General Permit for Storm Water Discharge \\ Industrial Associated with Industrial Activities \\ Permit \\ ISO International Organization for Standardization \\ $\mathrm{kg} \quad$ kilogram \\ $\mathrm{kg} / \mathrm{yr} \quad$ kilogram per year \\ LECS liquid effluent control system \\ LLNL Lawrence Livermore National Laboratory \\ MCLs maximum contaminant levels \\ $\mathrm{mg} / \mathrm{L} \quad$ milligrams per liter \\ mrem millirem \\ MS4 \\ California Small Municipal Separate Storm Sewer System \\ MSDS material safety data sheet \\ $\mathrm{mSv} \quad$ milliSeivert \\ ND non-detectable \\ NEPA National Environmental Policy Act \\ NESHAPs National Emission Standards for Hazardous Air Pollutants
}




\begin{tabular}{|c|c|}
\hline NFPA & National Fire Protection Association \\
\hline NNSA & National Nuclear Security Administration \\
\hline NNSA/SSO & National Nuclear Security Administration, Sandia Site Office \\
\hline NOV & Notice of violation \\
\hline NPDES & national pollutant discharge elimination system \\
\hline $\mathrm{O} \& \mathrm{G}$ & oil and grease \\
\hline PCB & polychlorinated biphenyl \\
\hline $\mathrm{pCi} / \mathrm{L}$ & picocuries per liter \\
\hline PFC & perfluorocarbon \\
\hline POTW & publicly owned treatment works \\
\hline $\mathrm{PP} / \mathrm{WM}$ & Pollution Prevention and Waste Minimization \\
\hline QAPP & quality assurance program plan \\
\hline RCRA & Resource Conservation and Recovery Act \\
\hline RWQCB & Regional Water Quality Control Board (California) \\
\hline $\begin{array}{l}\text { SARA } \\
\text { Title III }\end{array}$ & Superfund Amendments and Reauthorization Act of 1986, Title III \\
\hline SF6 & Sulfur Hexafluoride \\
\hline SHPO & State Historic Preservation Officer \\
\hline SNL & Sandia National Laboratories \\
\hline $\mathrm{SNL} / \mathrm{CA}$ & Sandia National Laboratories, California \\
\hline SNL/NM & Sandia National Laboratories, New Mexico \\
\hline SSP & Site Sustainability Plan \\
\hline SWEA & site-wide environmental assessment \\
\hline TPHD & total petroleum hydrocarbons diesel \\
\hline TSCA & Toxic Substances Control Act \\
\hline TSS & total suspended solids \\
\hline$\mu \mathrm{g} / \mathrm{L}$ & micrograms per liter \\
\hline U.S. & United States \\
\hline USC & United States Code \\
\hline USFWS & United States Fish and Wildlife Service \\
\hline UST & underground storage tank \\
\hline
\end{tabular}




\section{Executive Summary}

\subsection{Overview}

Sandia National Laboratories (SNL) is one of three national laboratories supporting the United States Department of Energy (DOE) statutory responsibilities for nuclear weapon research and design, development of energy technologies, and basic scientific research. SNL facilities are located in New Mexico, California, Nevada, and Hawaii. Sandia National Laboratories, California (SNL/CA) is a multi-program engineering and science laboratory supporting the nuclear weapons stockpile program, energy and environment research, homeland security, micro- and nano-technologies, and basic science and engineering research.

The Site Environmental Report provides a summary of environmental management performance and compliance efforts at SNL/CA for calendar year 2011. The document also satisfies the DOE requirement for preparation of an annual environmental report, one of the required reports listed in DOE Order 231.1B, Environment, Safety, and Health Reporting (DOE 2011d).

The Site Environmental Report is divided into ten chapters. Chapter 1, the Executive Summary, highlights compliance and monitoring results obtained in 2011. Chapter 2 provides a brief introduction to SNL/CA and the existing environment found on site. Chapter 3 summarizes SNL/CA's compliance activities with the major environmental requirements applicable to site operations. Chapter 4 presents information on environmental management, performance measures, and environmental programs. Chapter 5 presents the results of monitoring and surveillance activities in 2011. Chapter 6 discusses quality assurance. Chapters 7 through 9 provide supporting information for the report and Chapter 10 is the report distribution list.

\subsection{Environmental Management}

SNL/CA personnel maintain a comprehensive environmental management system (EMS) that incorporates environmental stewardship, compliance, and a process of continual improvement. SNL/CA's program conforms to the international standard for EMS, ISO 14001 (ISO 2004), obtaining re-registration on July 5, 2009. In 2011, SNL/CA was also a Waste Wise Partner (April 2008), a program sponsored by the Environmental Protection Agency. Additional information on environmental management is presented in Chapter 4.

\subsection{Performance Measures}

SNL/CA personnel measure environmental performance as progress towards achieving EMS objectives and contract performance measures established jointly between Sandia and the DOE National Nuclear Security Administration, Sandia Site Office (NNSA/SSO). During 2011, SNL/CA personnel measured performance in achieving all ten EMS objectives and one 
NNSA/SSO performance measure. The site received two notices of violation (NOVs) and three minor violations in 2011. The two NOVs resulted from violations of California hazardous waste regulations. The three minor violations relate to underground storage tank requirements. Section 3.6.3 provides details about the minor violations and Section 3.12 presents the details of the NOVs. Additional information about SNL/CA's environmental performance in 2011 is presented in Section 4.2.

\subsection{Environmental Monitoring}

SNL/CA personnel monitors storm water, wastewater, groundwater, and direct (ambient) radiation. The results of monitoring during the 2010/2011 wet season show that no pollutants were detected in storm water runoff at levels that are a cause for concern. During 2011, there were no exceedances of the wastewater discharge limit at the site sewer outfall. Monitoring results continued to show carbon tetrachloride in groundwater at the Navy Landfill in 2011 with a concentration similar to that detected in past years. Wells at the Fuel Oil Spill site were replaced in 2011. Analytical results of groundwater from the replacement wells showed residual total petroleum hydrocarbons-diesel $(210 \mu \mathrm{g} / \mathrm{L})$. The average annual gamma radiation dose from all sources including background radiation at the site perimeter was 62.9 mrem $(0.629 \mathrm{mSv})$, which is within the dose range measured over the last fifteen years. The measured background for this area is approximately $54.4 \mathrm{mrem}(0.544 \mathrm{mSv})$. The difference between the two values is statistically significant. Additional information about environmental monitoring at SNL/CA is provided in Chapter 5. 


\section{Introduction}

\subsection{History and Mission}

Sandia National Laboratories, California (SNL/CA) was established in 1956 by Sandia Corporation (Sandia) to provide a closer relationship with Lawrence Livermore National Laboratory (LLNL) and their nuclear weapons design work. The SNL/CA facility evolved into an engineering research and development laboratory by the early 1960s, and into a multi-program engineering and science laboratory during the 1970s. As international arms control efforts increased in the late 1970s and throughout the 1980s, the United States emphasized treaty monitoring, safety, security, and control of the national nuclear weapons stockpile. With the end of the Cold War in the late 1980s, the role of SNL/CA to support stockpile stewardship ensuring nonproliferation and continued safety, security, and reliability, took on greater importance.

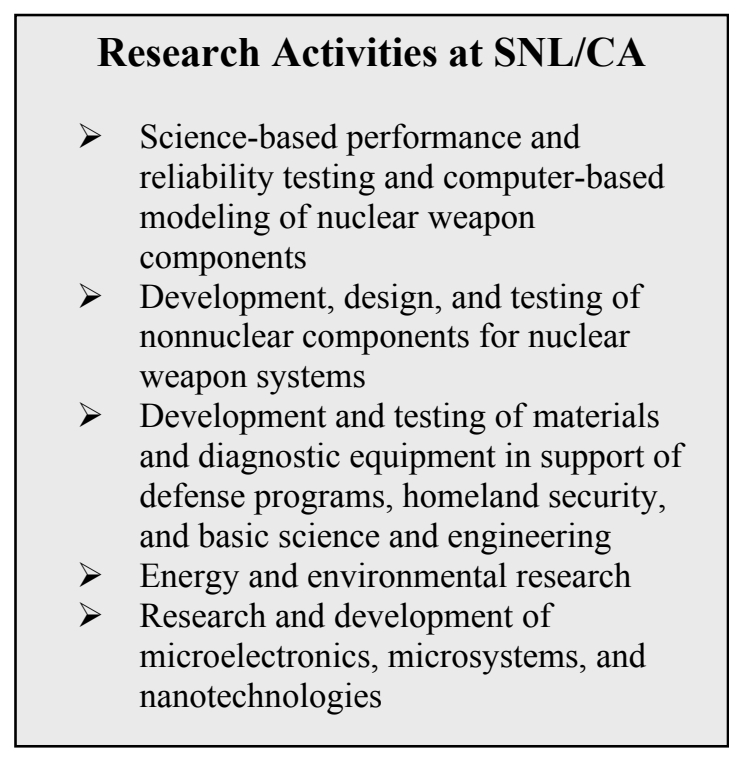

SNL/CA personnel have provided distinguished service to the nation for over 50 years through engineering support and systems integration for nuclear weapons and related national security research and development efforts. Our programs support four key areas the national nuclear deterrence policy and stockpile security, nonproliferation and materials control, energy and critical infrastructure, and emerging threats. SNL/CA personnel are committed to collaborative research and development with industry and universities, resulting in new and enhanced technologies that have both commercial and national security benefits.

SNL/CA is a government owned/contractor operated laboratory. The site, the buildings, and the equipment are owned by the government; while Sandia Corporation, a wholly-owned subsidiary of Lockheed Martin Corporation, manages and operates the laboratory for the Department of Energy's National Nuclear Security Administration (NNSA). The 
NNSA/Sandia Site Office (NNSA/SSO) oversees the operations at the site, using Sandia Corporation as a management and operating contractor.

\subsection{Location}

SNL/CA is located approximately 40 miles east of San Francisco, near the City of Livermore in eastern Alameda County. The site lies at the western base of the Altamont Hills on relatively flat terrain with low relief sloping gently northwest and north. Figure 2-1 shows the regional location of the site.

$\mathrm{SNL} / \mathrm{CA}$ is comprised of 410 acres. The main campus (134 acres) is surrounded by the remaining undeveloped SNL/CA land (276 acres) on the east, south, and west (Figure 2-2, Site Map). To the north of SNL/CA are East Avenue and LLNL. Land use to the east and south of the site is agricultural and low-density residential. A residential development is located along the western boundary of the site. 


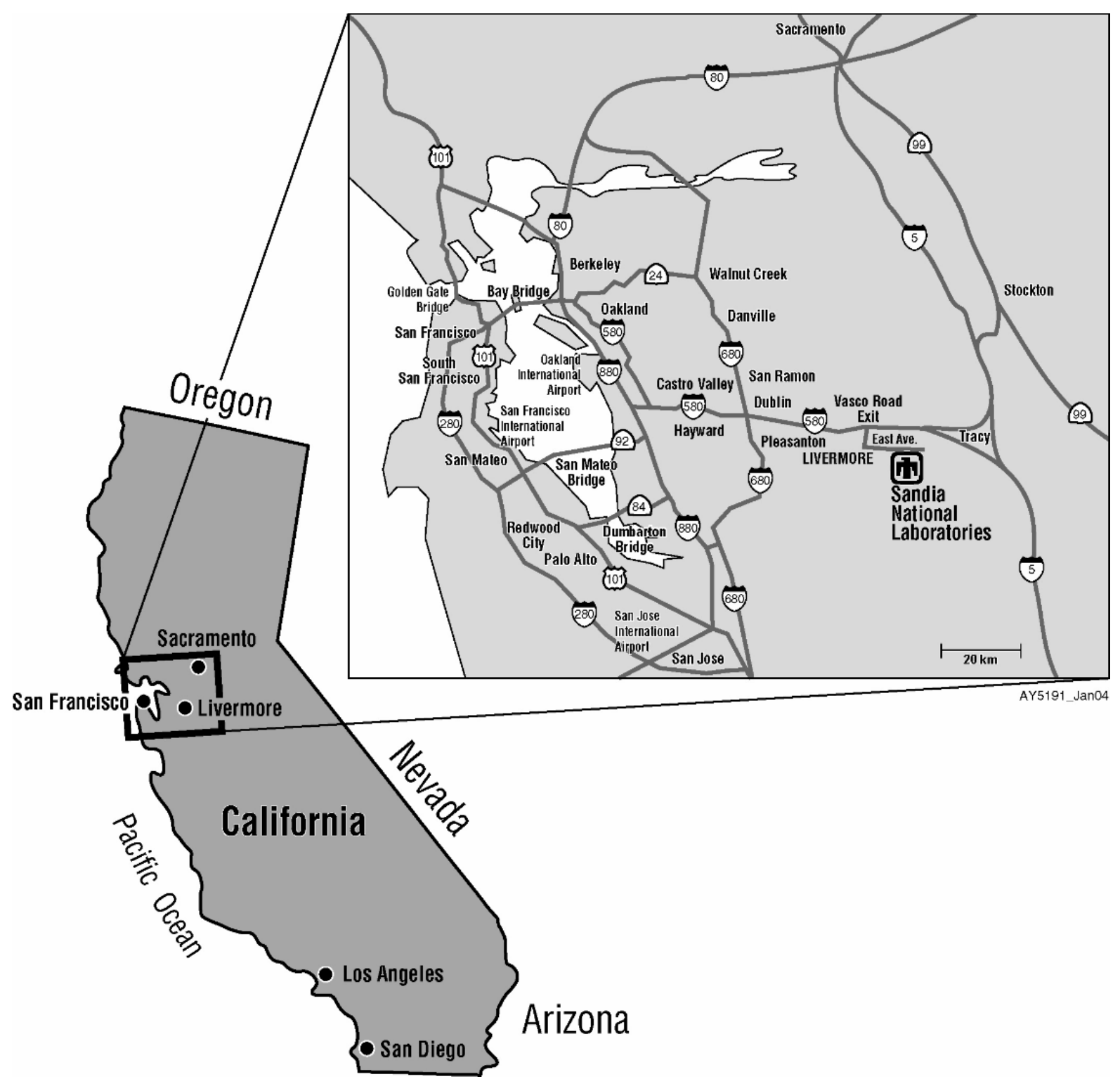

Figure 2-1 Regional Location Map 


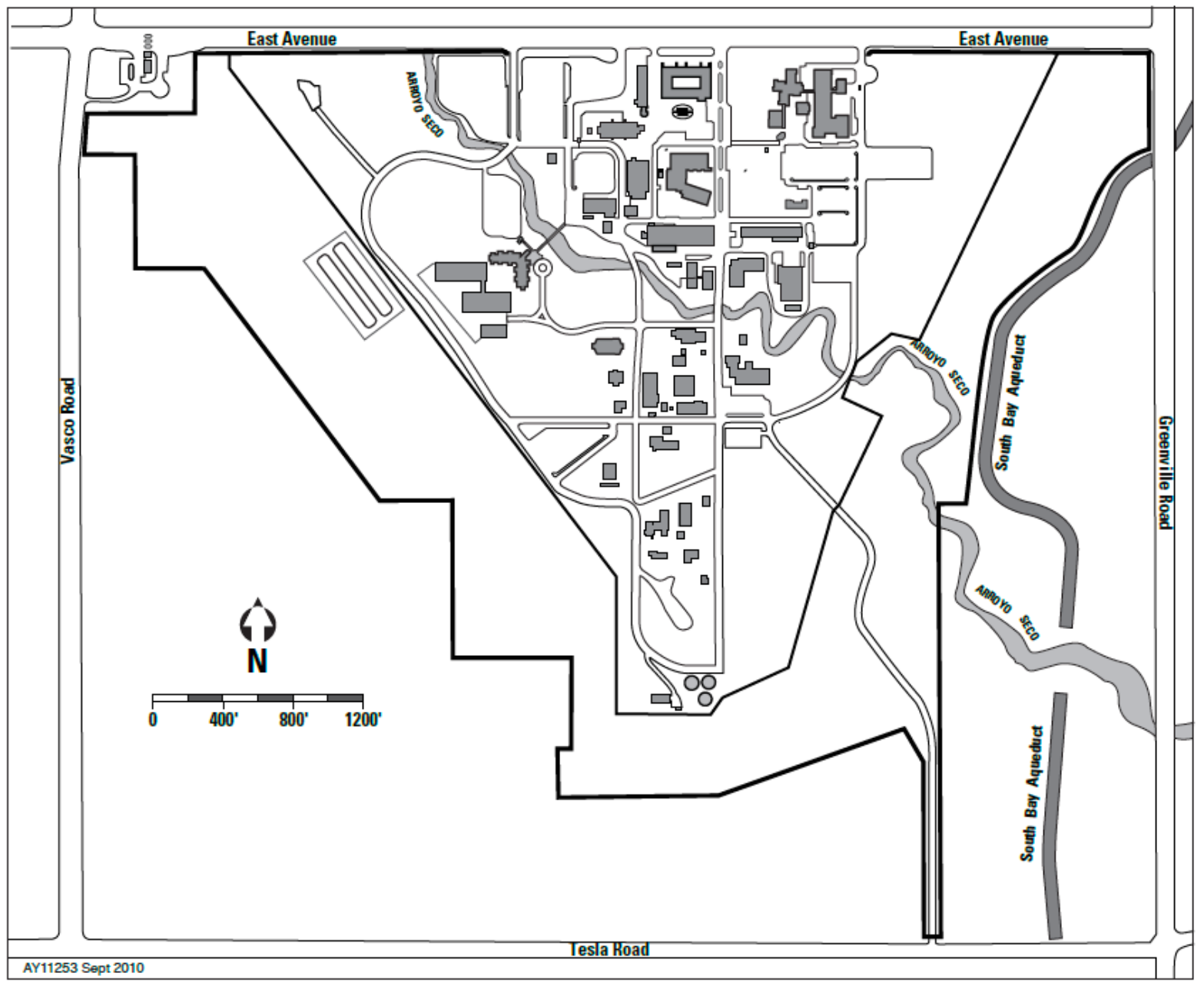

Figure 2-2 SNL/CA Site Map

\subsection{Site Population}

The SNL/CA workforce is comprised of Sandia employees (full and part-time staff, student interns, and post-doctoral appointees) and contracted staff. As of December 2011, there were 1313 personnel (employees and on-site contractors) working at SNL/CA. During 2011, the number of Sandia employees increased by 26 from 2010 levels. Eighty-one percent of Sandia employees live in Alameda, Contra Costa, and San Joaquin counties. Thirty-three percent live in Livermore. Place of residence data is not available for on-site contractors.

\subsection{Environmental Setting}

The following summarizes the environmental setting at SNL/CA. Additional information can be found in the Final Site-wide Environmental Assessment of the Sandia National Laboratories/California (DOE 2003a). 


\subsubsection{Geology and Soils}

$\mathrm{SNL} / \mathrm{CA}$ is located in the California Coast Ranges geologic province in the southeastern portion of the Livermore Valley. The valley forms an irregularly shaped lowland area about 16 miles long, east to west, and 7 to 10 miles wide, north to south. The land at SNL/CA slopes gently to the northwest and north, with steep terrain in the southern portion of the site and along the banks of Arroyo Seco. The site ranges in elevation from 615 feet above mean sea level at the northwest corner of the property to 849 feet at the southern end. Site topography is depicted on Figure 2-3.

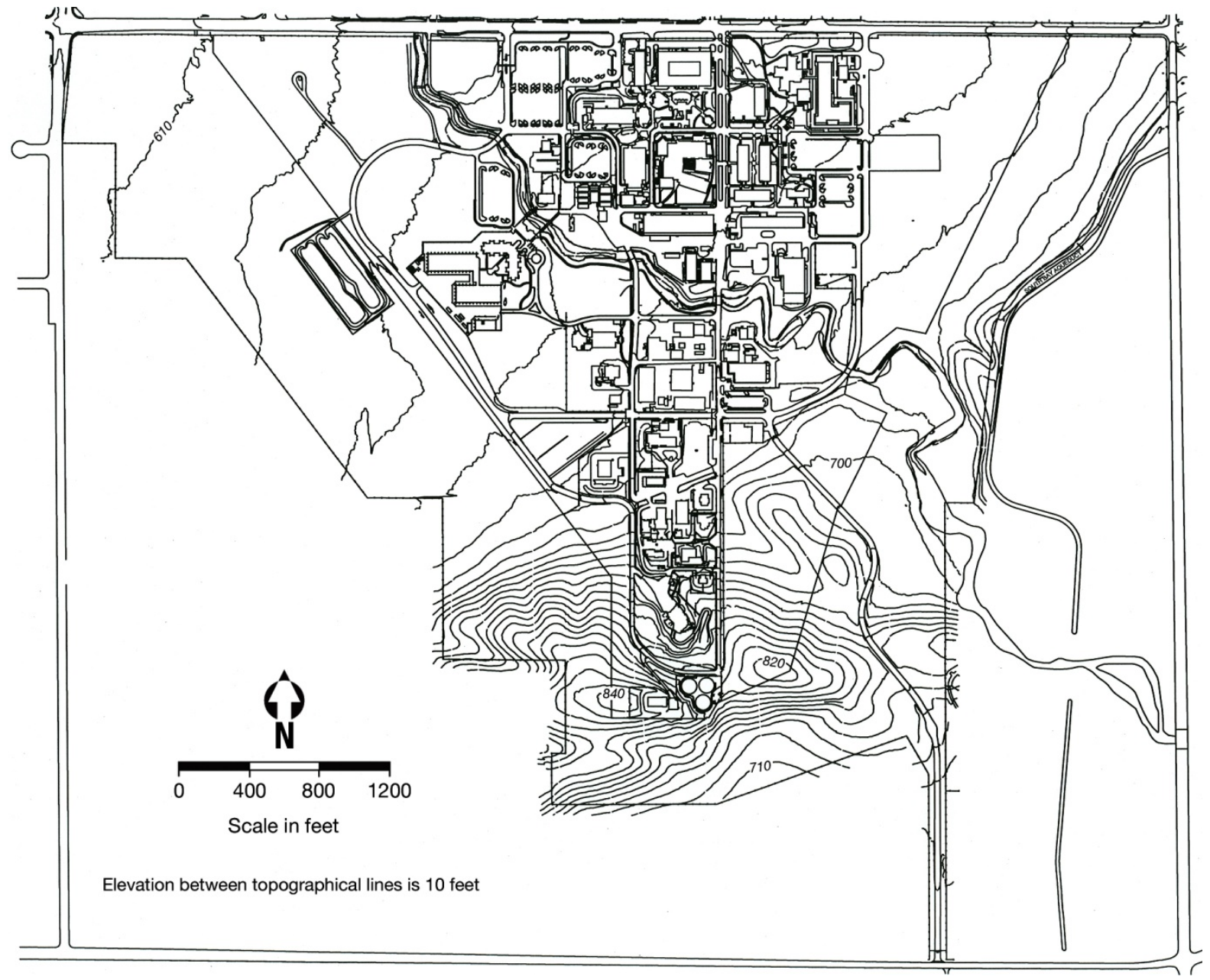

Figure 2-3 SNL/CA Topography

$\mathrm{SNL} / \mathrm{CA}$ is located in a seismically active region. The major fault systems in the area are the San Andreas Fault system and the much older Coast Range thrust fault system. The upper plate of the Coast Range thrust formed the northwest trending Coast Range, including the Altamont Hills. Any seismic activity in the Livermore Valley would probably result from movement on the San Andreas Fault, a right-lateral strike-slip fault system trending northwest-southeast, extending from Point Arena to the Gulf of California. The regional faults closest to SNL/CA, the Hayward, Calaveras, Greenville, and Tesla faults follow this trend, and have been seismically active in the historic past. A magnitude 5.8 earthquake on 
the Greenville fault in 1980 caused minor damage at SNL/CA and in the Livermore Valley. The Las Positas fault crossing SNL/CA is a transverse fault, at right angles to the Greenville fault, and was active during this earthquake. The Verona fault is a low angle thrust fault, dissimilar to the regional faulting, and probably not connecting with either the Calaveras or Las Positas faults. Only microseismicity was recorded on the Verona fault in 1980. These faults are shown on Figure 2-4.

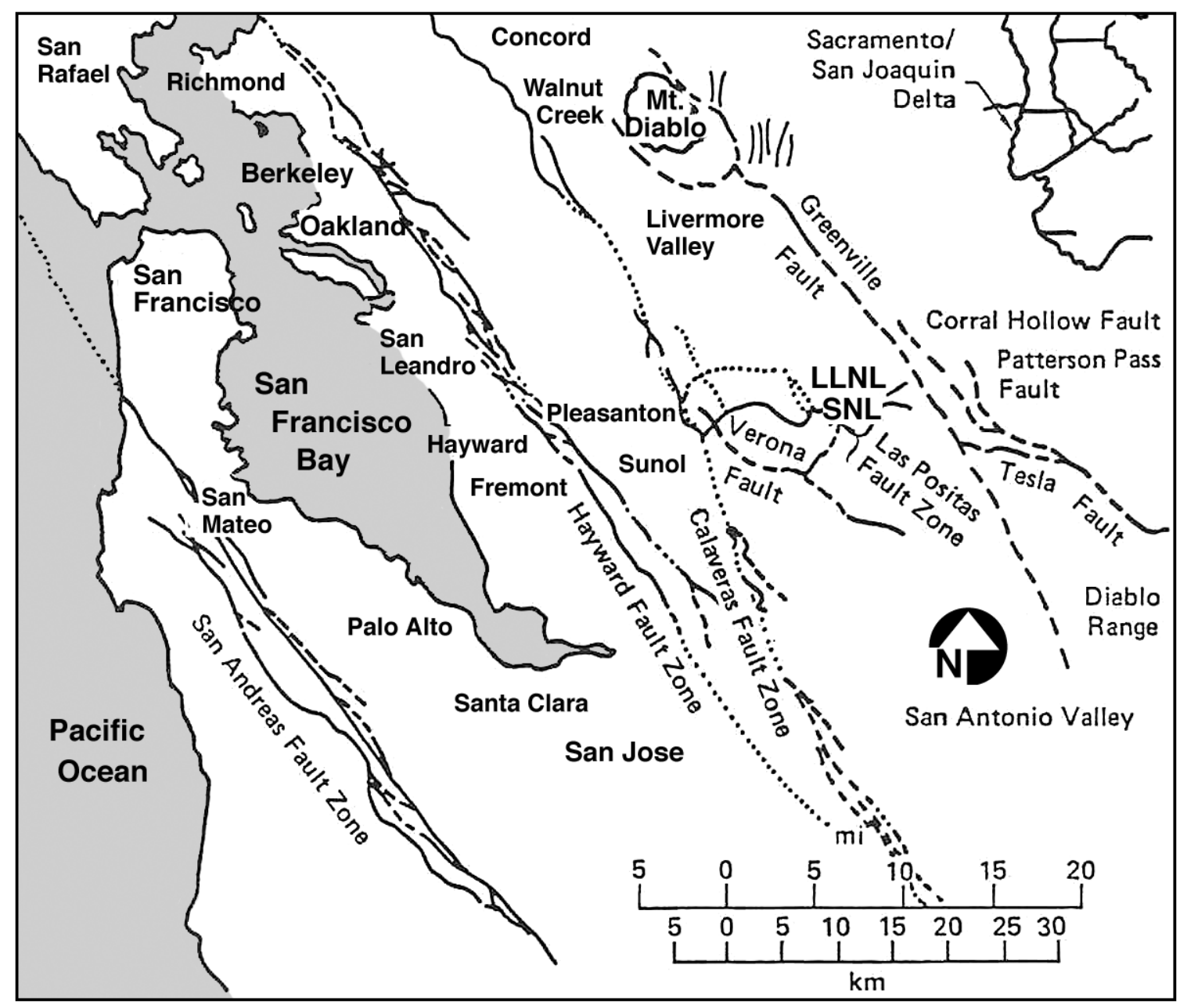

Figure 2-4 Regional Earthquake Faults

Surface soils and arroyo sediments cover the SNL/CA site. Underlying soils at the site are formed primarily upon sediments deposited by local streams. Three soils cover most of SNL/CA: Rincon clay loam, Positas gravelly loam, and Livermore gravelly loam. There are no known mineral resources or fossil occurrences at the site.

\subsubsection{Hydrology and Water Resources}

Groundwater in the SNL/CA area occurs within saturated unconsolidated geologic material. Depth to groundwater varies from less than 20 feet on the eastern portion of the site to 126 feet on the west side of the site. Water bearing-units beneath the site are composed of shallow heterogeneous, unconsolidated alluvium and deep fluvial and lacustrine sediments. 
Groundwater near SNL/CA is generally suitable for use as domestic, municipal, agricultural, and industrial supply. However, some shallower groundwater may be of marginal quality and not suitable for industrial or agricultural purposes. Groundwater less than 300 feet deep is usually unsuitable for domestic use without treatment.

Potable water used at SNL/CA is purchased from LLNL, which is supplied by the San Francisco Water District through the Hetch Hetchy Aqueduct. Additionally, the Alameda County Flood Control and Water Conservation District, Zone 7, supplements this primary water source as needed. SNL/CA's water use is metered by LLNL as it enters the site. In calendar year 2011, 56.18 million gallons of water were used at SNL/CA, a decrease of 0.64 percent (386,000 gallons) from water used in 2010. (See discussion in Section 4.2). The site discharged approximately 9.2 million gallons of wastewater during the year. Water loss, or the difference between water use and wastewater discharge, is attributed to irrigation, cooling towers, water tank releases, evaporative losses, eyewash and safety shower testing, and fire system testing.

There are no perennial streams or natural surface water bodies at SNL/CA. The Arroyo Seco, an ephemeral and intermittent stream, diagonally traverses the site from southeast to northwest. The arroyo typically flows only in very wet years, and for short periods of time during heavy storms. A seasonal wetland that is wet well into June, and sometimes July, is located in the streambed along the eastern part of the arroyo. Storm water runoff at SNL/CA is conveyed to Arroyo Seco through a system of storm drains and channels. The Arroyo Seco and seasonal wetland are shown on Figure 2-5.

\subsubsection{Climate and Meteorology}

The climate at SNL/CA is typical of the Mediterranean conditions in the San Francisco Bay region where cool, wet winters and hot, dry summers are normal. In the summer, inland valleys, such as the Livermore Valley, generally experience more sunshine and higher temperatures than the coastal areas. In the winter, temperatures in the valley are usually cooler than at the coast.

Annual meteorological data for 2011 was obtained from a nearby meteorological tower located at LLNL (LLNL 2012). The annual rainfall for 2011 was 9.94 inches. Temperatures in 2011 ranged from 25.0 to $99.5^{\circ}$ Fahrenheit. Average annual rainfall in the Livermore area over the last five years was 11.22 inches. The windiest months in the area occur in the spring and summer, and are dominated by westerly sea breezes. The winds during the fall and winter are typically lighter and more varied in direction.

\subsubsection{Ecology}

\section{Plant Species}

The plant community at SNL/CA is typical of the surrounding region, consisting primarily of grassland. Localized areas of coyote brush scrub, willow riparian woodland, and wetland habitat are also present. Areas developed and disturbed by Sandia operations constitute an 
additional habitat type, designated altered habitat. Habitat types are depicted on Figure 2-5. No threatened, endangered, proposed, or candidate plant species are present onsite.

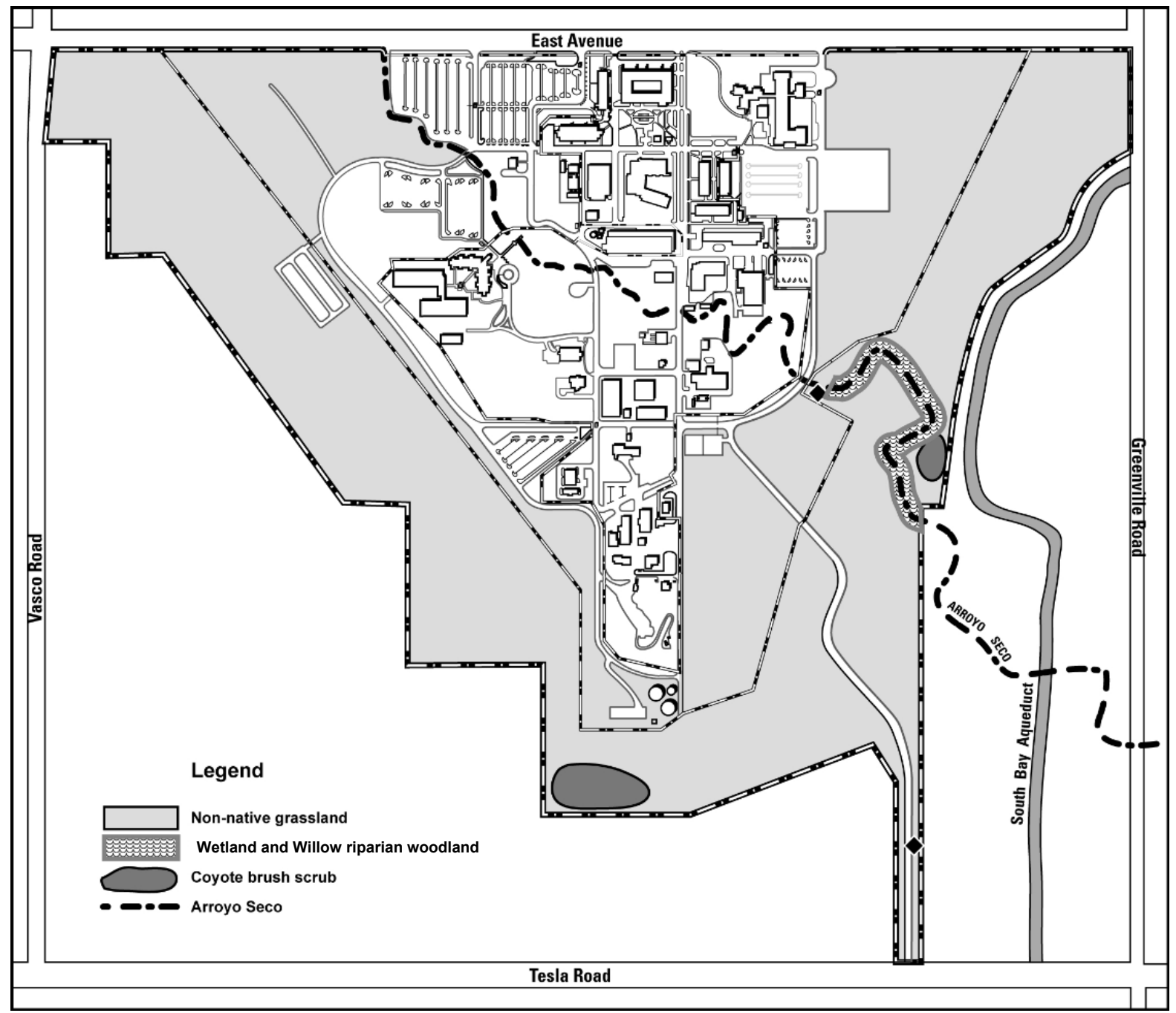

Figure 2-5 Habitat at SNL/CA

\section{Wildlife Species}

A variety of wildlife species live and forage at SNL/CA. In 2011, annual monitoring of common species was discontinued; consequently, species counts provided in past reports are not available this year. Table 2-1 provides a list of animals frequently seen on site. State and Federally protected animals are not included in this list but discussed separately below.

$\mathrm{SNL} / \mathrm{CA}$ is located within the range of the mountain lion (Puma concolor), a "specially protected mammal" under California law. SNL/CA received one unconfirmed report of a mountain lion on site in 2011.

SNL/CA provides habitat (or potential habitat) for two threatened wildlife species, the California red-legged frog (Rana aurora draytonii) and the California tiger salamander (Ambystoma californiense). The most recent confirmed observation of a tiger salamander at 
SNL/CA was on December 13, 2007, when an adult salamander was found within the developed area of the site. The first confirmed observation of California red-legged frogs at SNL/CA occurred in April 2004 when several individuals were found on the eastern portion of the site in shallow water contained within Arroyo Seco. The most recent observation of red-legged frogs at SNL/CA was in 2010. Monitoring for California red-legged frogs is conducted annually, but none were observed in 2011.

Table 2-1 Frequently Seen Animals at SNL/CA

\begin{tabular}{|c|c|c|c|}
\hline \multicolumn{4}{|c|}{ BIRDS } \\
\hline American crow & Corvus brachyrhynchos & Northern mockingbird & Mimus polyglottos \\
\hline American kestrel & Falco sparverius & Nuttall's woodpecker & Picoides nuttallii \\
\hline American robin & Turdus migratorius & Red-tailed hawk & Buteo jamaicensis \\
\hline Anna's hummingbird & Calypte anna & Turkey vulture & Cathartes aura \\
\hline Barn owl & Tyto alba & Western kingbird & Tyrannus verticalis \\
\hline Bushtit & Psaltriparus minimus & Western meadowlark & Sturnella neglecta \\
\hline California towhee & Pipilo crissalis & Western scrub jay & Aphelocoma californica \\
\hline Golden-crowned sparrow & Zonotrichia atricapilla & White-crowned sparrow & Zonotrichia leucophrys \\
\hline Kildeer & Charadrius vociferous & White-tailed kite & Elanus leucurus \\
\hline Northern flicker & Colaptes auratus & Yellow-rumped warbler & Dendroica coronata \\
\hline \multicolumn{4}{|c|}{ MAMMALS } \\
\hline American badger & Taxidea taxus & Fox squirrel & Sciurus niger \\
\hline $\begin{array}{l}\text { California ground } \\
\text { squirrel }\end{array}$ & Spermophylus beecheyii & Raccoon & Procyon lotor \\
\hline Coyote & Canis latrans & Red fox & Vulpes vulpes \\
\hline Desert cottontail & Sylvilagus audubonii & Striped skunk & Mephitis mephitis \\
\hline \multicolumn{4}{|c|}{ REPTILES AND AMPHIBIANS } \\
\hline Pacific chorus frog & Pseudacris regilla & Western fence lizard & Sceloporus occidentalis \\
\hline Pacific gopher snake & $\begin{array}{l}\text { Pituophis catenifer } \\
\text { catenifer }\end{array}$ & Western toad & Bufo boreas \\
\hline
\end{tabular}




\section{Compliance Summary}

Sandia National Laboratories, California (SNL/CA) operates in compliance with the letter and spirit of applicable federal, state, and local environmental laws and regulations. Additionally, as a Department of Energy (DOE) facility, the site is subject to DOE directives (DOE orders) and to presidential executive orders. This chapter provides a summary of SNL/CA compliance with major environmental requirements for calendar year 2011.

\subsection{Environmental Management System and Sustainability}

The requirement for an EMS at SNL/CA was initially driven by DOE Order 450.1A, Environmental Protection Program. Order 450.1A was cancelled in 2011 and replaced by Order 436.1, Departmental Sustainability. DOE Order 436.1, Departmental Sustainability was established to ensure that an EMS and site sustainability are at the forefront of environmental excellence. Although the complete order is not within the Sandia Management and Operations Contract (M\&O Contract), the intent of the order is implemented through the M\&O Contract requirement for an International Organization for Standardization (ISO) 14001 certified EMS.

DOE Order 436.1 also cancelled Order 430.2B, Departmental Energy, Renewable Energy and Transportation Management which identified requirements and responsibilities for efficient and effective management of energy, water, and fleet vehicles at DOE facilities. Sandia is subject to DOE Order 436.1 requirements for establishing and implementing a site sustainability plan. Sandia developed a corporate-wide Site Sustainability Plan that addresses energy, water, fuels, and a variety of other environmental concerns. SNL/CA personnel follow the corporate Plan, but continue to maintain a site-specific EMS.

Sandia implemented its EMS in December 2005. In 2006, the SNL/CA EMS Program was upgraded to conform to the international standard for EMS, ISO 14001:2004 and received third-party registration to the standard. In 2009, re-registration of the SNL/CA EMS Program was received for an additional three-year period. The next three-year re-registration audit will be conducted in May 2012. Chapter 4 provides additional information on SNL/CA's EMS program.

The Sandia Site Sustainability Plan address the following DOE reporting requirements:

$>$ DOE's Annual Energy Report, as required by the National Energy Conservation Policy Act, Energy Policy Act of 2005, and Energy Independence and Security Act of 2007 (EISA 2007);

$>$ Section 432 of EISA 2007, which requires reporting of energy and water conservation measures that are identified as a result of site audits; and

$>$ Commitments in the DOE Strategic Sustainability Performance Plan (SSPP). 
In 2011, SNL/CA personnel provided input to the reports identified above and participated in development of the Site Sustainability Plan for FY2012. Chapter 4 presents additional information about the specific objectives and targets that support these requirements.

\subsection{National Environmental Policy Act}

The National Environmental Policy Act (NEPA) (42 USC § 4321) is the basic national charter for protection of the environment. It requires all federal agencies to evaluate the effects of major federal actions on the human environment, including the physical, socioeconomic, and cultural environments. NEPA review of DOE actions is conducted in accordance with DOE NEPA Implementing Procedures (10 CFR 1021). Under these procedures, DOE may prepare a programmatic (including site-wide) document at any time to further the purposes of NEPA. In 2003, DOE's National Nuclear Security Administration/ Sandia Site Office (NNSA/SSO) issued a site-wide environmental assessment (SWEA) for continued operations at SNL/CA (DOE 2003a) and a Finding of No Significant Impact (FONSI) on March 20, 2003 (DOE 2003b). The SWEA provides an evaluation of the impacts of site operations over the next ten years, and the FONSI concludes that continuation of site operations is not a major federal action significantly affecting the quality of the human environment.

In 2011, NNSA/SSO initiated a review of SNL/CA's SWEA through a supplement analysis. The results of the analysis are pending and will be presented in the 2012 report.

SNL personnel support compliance with NEPA and DOE's NEPA Implementing Procedures by reviewing all new projects and programs or changes to existing projects and programs to ensure that they fit within the bounds of existing NEPA documents and impact analyses for the site. During fiscal year 2011, 91 projects underwent NEPA review. None of these projects required the preparation of an environmental assessment or an environmental impact statement.

\subsection{Air Quality}

\subsubsection{Clean Air Act}

The Clean Air Act (42 USC $\S 7401$ ) is the federal statute that forms the basis for the national air pollution control effort. It authorizes the Environmental Protection Agency (EPA) to promulgate air quality regulations and establishes national ambient air quality standards for criteria pollutants. Authority to implement the requirements of the Clean Air Act is provided to each state that has an EPA approved State Implementation Plan. The State Implementation Plan for California describes how National Ambient Air Quality Standards will be obtained in each air district. Each district establishes and enforces air pollution regulations to attain and maintain state and federal ambient air quality standards. The Bay Area Air Quality Management District (BAAQMD) is the regulating authority for controlling air pollution from stationary sources at SNL/CA. The California Air Resources Board (CARB) is responsible for ensuring that federal and state standards are met for mobile and small "area" sources of air pollution. 
SNL/CA does not have any major sources of air pollutants (as defined in 40 CFR Part 70.2) present on site. SNL/CA personnel work with the BAAQMD and CARB to permit or register all regulated emission sources. There were 13 permitted sources for the 2010/2011 and 2011/2012 permitting periods ${ }^{1}$. Table 3-4 (Section 3.13) provides a list of the permitted sources.

\subsubsection{Radionuclide Emissions}

The National Emissions Standards for Hazardous Air Pollutants, Subpart H - National Emission Standards for Emissions of Radionuclides Other Than Radon From Department of Energy Facilities (NESHAPs) (40 CFR Part 61) establishes radiation protection standards, monitoring requirements, and annual reporting of radionuclide air emissions. Additional requirements pertaining to radionuclide emissions are contained in DOE Order 458.1 Radiation Protection of the Public and the Environment (DOE 2011c).

SNL/CA does not currently have any radionuclide emission sources that are subject to the monitoring requirements of 40 CFR Part 61. To comply with national emission standards, $\mathrm{SNL} / \mathrm{CA}$ personnel evaluate individual projects with the potential to release radionuclide emissions to determine the worst-case dose to the public. Additionally, dose calculations are compared to the requirements to determine the need for annual monitoring. During 2011, there were no projects using radionuclides above the Annual Possession Quantity; consequently, no NESHAPs evaluations were completed.

\subsection{Natural and Cultural Resources}

\subsubsection{Endangered Species Act}

The Endangered Species Act (16 USC § 1531 et. seq.) provides for protection of plant and wildlife species in danger of becoming extinct. In 2002, NNSA/SSO and SNL/CA personnel initiated consultation with the U.S. Fish and Wildlife Service (USFWS) under Section 7 of the Endangered Species Act for maximum operations of the SNL/CA site. On December 8, 2004, the USFWS issued a biological and conference opinion for continued operations at $\mathrm{SNL} / \mathrm{CA}$. The biological opinion concludes that proposed site operations are not likely to jeopardize the continued existence of the California red-legged frog (Rana aurora draytonii) and the California tiger salamander (Ambystoma californiense), the two threatened species present on site. The conference opinion concludes that site operations are not likely to destroy or adversely modify proposed critical habitat for the red-legged frog ${ }^{2}$.

\footnotetext{
${ }^{1}$ The BAAQMD permit period is July 1 through June 30 each year. Permit data is presented for the two periods applicable to 2011 .

${ }^{2}$ In 2002, when the consultation process began, the Sandia site was within designated critical habitat for the California red-legged frog. In November 2002, the designation was overturned (U.S. District Court 2002), and in April 2004, the USFWS re-issued proposed critical habitat that included the Sandia site (USFWS 2004). However, in November 2005, the USFWS issued a revised designation (USFWS 2005), and a final rule in April 2006 (USFWS 2006). The scientific integrity of the 2006 rule was questioned resulting in another revision to critical habitat. The USFWS issued a new designation in March 2010. The Sandia site is not included in the final determination of critical habitat for the California red-legged frog.
} 


\subsubsection{Interim Protections for California Red-legged Frogs}

In October 2006, interim restrictions on pesticide use went into effect to protect the California red-legged frog. The restrictions are the result of a settlement agreement between the EPA and the Center for Biological Diversity that requires the EPA to consult with the USFWS under the Endangered Species Act on the impacts of 66 pesticide ingredients to the red-legged frog. The agreement, outlined in a Stipulated Injunction and Order (US District Court 2006), places restrictions on the use of these pesticides in red-legged frog aquatic and upland habitat until consultations are complete and biological opinions are issued by the USFWS. In response to these interim protections, products containing the named pesticide ingredients are restricted from use in and along Arroyo Seco. By December 31, 2009, the EPA had completed effects determinations (or canceled the registration) for all 66 pesticide ingredients but no opinions have yet been issued.

\subsubsection{Migratory Bird Treaty Act}

The Migratory Bird Treaty Act (16 USC $\$ 703$ et. seq.) provides for protection of migratory birds, their nests, and eggs. Most of the bird species observed at SNL/CA are protected under this act. In 2011, there was no intentional take of migratory birds or disturbance to nests or eggs at the site. Migratory birds often build nests within the developed campus in locations where they will be disturbed by maintenance activities. To avoid harming birds, nests, or eggs, SNL/CA activities are delayed until the young have fledged, or surveys determine that the nest is abandoned. In 2011, one activity was delayed to protect nesting birds.

\subsubsection{Protection of Wetlands}

Executive Order 11990, Protection of Wetlands (EO 11990), requires federal agencies to minimize the destruction, loss, or degradation of wetlands and preserve and enhance the natural and beneficial values of wetlands. A small wetland area of 0.44 acres is present at SNL/CA. During 2011, no activities were conducted in the wetland area, or affecting wetlands.

\subsubsection{Floodplain Management}

Executive Order 11988, Floodplain Management (EO 11988), requires federal agencies to consider impacts associated with the occupancy and modification of floodplains, to reduce the risk of flood loss, to minimize the impact of floods on human safety, health, and welfare, and to restore and preserve the natural and beneficial values served by floodplains. In 2002, a management plan for the Arroyo Seco was completed to identify channel improvements and stream zone management activities that will reduce flood and erosion risk and provide improved habitat for wildlife species that may use the arroyo (Matthews 2002). The plan identifies areas for constructing functional floodplains and for planting of native riparian vegetation. During 2006 and 2007, five improvement tasks were completed under a two-year permit issued by the U.S. Army Corp of Engineers. A new permit request was submitted in 2006 for the remaining improvement actions. In September 2008, a new ten-year permit for 
SNL/CA was received from the U.S. Army Corp of Engineers to continue the Arroyo Seco Improvement Program. Nine improvement projects have been completed to date. Restored areas are monitored annually to determine progress in meeting survival and growth criteria established in the permit. When needed, shrubs and trees are replanted or grasses reseeded. No reseeding or replanting was needed in 2011.
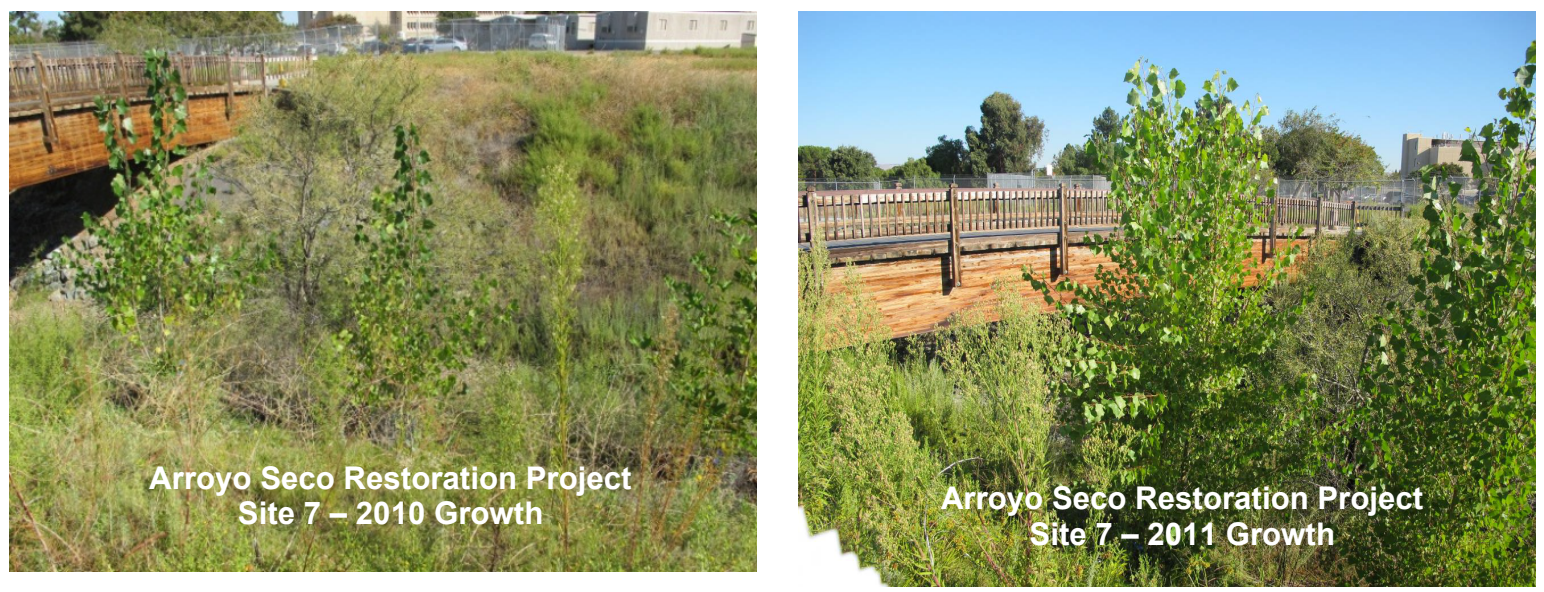

\subsubsection{National Historic Preservation Act}

The National Historic Preservation Act (16 USC $\S 470$ ) requires federal agencies to identify, record, and protect cultural resources. In 1990, an assessment of cultural resources at the $\mathrm{SNL} / \mathrm{CA}$ site was completed. Although no prehistoric resources, Native American resources, or historic archaeological sites were identified during this assessment, there is a possibility that buried resources could be present on site (DOE 2003a). Provisions for cultural resources are included in all construction-related contracts where the potential for buried resources may be unearthed. In 2011, there were no buried archaeological resources unearthed at SNL/CA.

In 2001, SNL personnel completed an historic building survey. None of the buildings onsite are identified as historically significant or eligible for the National Register of Historic Places (SNL 2002). The results of the historic building survey were submitted to NNSA/SSO. In December 2004, NNSA transmitted the survey results to the California State Historic Preservation Officer (SHPO). In April 2005, NNSA/SSO received concurrence from the California SHPO that none of the properties located at SNL/CA are eligible for inclusion in the National Register of Historic Places.

\subsection{Environmental Restoration}

\subsubsection{Comprehensive Environmental Response, Compensation, and Liability Act}

Between 1984 and 1986, DOE investigated the SNL/CA site under their Comprehensive Environmental Assessment and Response Program (CEARP) to identify and assess potential environmental problems (DOE 1986). The CEARP investigation evaluated compliance with 
major federal environmental laws, including the Comprehensive Environmental Response, Compensation, and Liability Act (CERCLA) (42 USC § 9601). CERCLA established liability compensation, cleanup, and emergency response for hazardous substances released to the environment. During the CEARP investigation, two potential CERCLA sites were identified at SNL/CA, the Fuel Oil Spill Site and the Navy Landfill. A Hazard Ranking System study was performed for each site to determine if either qualified for listing on the National Priorities List. Hazard Ranking System scores for both sites fell below 28.5, the qualifying score for listing. Since completion of the CEARP investigation, there have been no hazardous substance releases or contaminated sites found at SNL/CA that warranted CERCLA investigation or a Hazard Ranking System study.

In addition to cleanup and emergency response requirements, CERCLA also established a program to report spills of hazardous substances to the National Response Center. CERCLA reporting requirements are incorporated into an operating procedure for spill prevention and control (SNL/CA 2010). In 2011, there were no releases of hazardous substances that required notification under CERCLA.

\subsubsection{Site Clean-up Orders}

Since 1985, environmental restoration and monitoring activities at SNL/CA have been conducted in compliance with site clean-up orders issued by the California Regional Water Quality Control Board, San Francisco Bay Region under provisions established in the California Water Code (California RWQCB 1989). Although there are no active remediation sites at SNL/CA, groundwater monitoring is ongoing at two locations, the Fuel Oil Spill site and the Navy Landfill. SNL/CA personnel currently sample three groundwater monitoring wells for residual contamination, two at the Fuel Oil Spill site (when there is sufficient water to collect a sample), and one at the Navy Landfill. Sampling results are presented in Chapter 5, Environmental Monitoring.

\subsection{Chemical Management}

\subsubsection{Emergency Planning and Community Right-to-Know Act}

The Emergency Planning and Community Right-to-Know Act (EPCRA) -- also known as the Superfund Amendments and Reauthorization Act of 1986, Title III (SARA Title III) (42 USC $\S 11001$, et. seq.) -- requires reporting of toxic chemical usage and releases. To meet EPCRA requirements, SNL/CA personnel submit annual reports to the EPA, the State of California Office of Emergency Services, the Livermore-Pleasanton Fire Department, and the Alameda County Fire Department at LLNL. EPCRA reporting requirements applicable to SNL/CA for 2011 are presented in Table 3-1. 
Table 3-1 Status of EPCRA Reporting at SNL/CA, 2011

\begin{tabular}{llc}
\hline EPCRA Section & Description of Reporting & Required in 2011 \\
\hline Sec. 302-303 & Planning Notification & $\begin{array}{c}\text { Yes } \\
\text { (sulfuric acid only) }\end{array}$ \\
\hline Sec. 304 & Extremely Hazardous Substances Release Notification & No \\
\hline Sec. 311-312 & Material Safety Data Sheet/ Chemical Inventory & Yes \\
\hline Sec. 313 & Toxic Release Inventory Reporting & Yes (lead only) \\
\hline
\end{tabular}

\subsubsection{California Hazardous Materials Release Response Plans and Inventory Law}

The California Hazardous Materials Release Response Plans and Inventory Law (Assembly Bill 2185) addresses the management of hazardous and acutely hazardous materials in the state. Additional requirements pertaining to hazardous materials are codified in the California Health and Safety Code, Division 20, Chapter $6.95 \$ 25500$, et seq. In compliance with California requirements, SNL/CA personnel annually submit a Hazardous Material Business Plan to the Livermore-Pleasanton Fire Department.

\subsubsection{Underground Storage Tanks}

Hazardous or petroleum products stored in underground storage tanks (UST) are regulated under California Health and Safety Code Division 20, Chapter 6.7, §§ 25280-25299.8. California code incorporates the UST provisions of the Resource Conservation and Recovery Act (RCRA) and establishes standards for construction, operation, maintenance, inspection, and testing of USTs. The Livermore-Pleasanton Fire Department is the regulating authority for USTs at SNL/CA. SNL/CA personnel operate one UST in accordance with California requirements. Each year, the UST is declared through the Hazardous Material Business Plan described in Section 3.6.2, and it receives a permit to operate from the Livermore-Pleasanton Fire Department.

During 2011, SNL/CA received three minor violations associated with the UST from the Alameda County Department of Environmental Health ${ }^{3}$ for outdated certification, inaccurate and incomplete reports, and presence of standing water in the sump. The minor violations were corrected by Sandia personnel.

\subsubsection{Toxic Substances Control Act}

The Toxic Substances Control Act (TSCA) is the primary Federal statute regulating the manufacture, use, distribution, disposal, import, or export of certain chemicals and substances (15 USC $\S 2601$ et. seq.). TSCA requirements that are applicable to Sandia operations are incorporated into Corporate Process ESH100.2 Analyze and Control Hazards (SNL 2011). For SNL/CA operations, the only TSCA regulated chemicals imported or exported are for research and development purposes thus exempt from general reporting

\footnotetext{
${ }^{3}$ On September 8, 2011, the regulating authority for USTs changed to the Livermore-Pleasanton Fire Department CUPA (Certified Unified Program Agencies) when the SNL/CA site was annexed into the Livermore city limits. Future inspections will be conducted by the new CUPA.
} 
requirements. However, SNL/CA personnel notify EPA of exempt imports and exports when appropriate. In 2011, no TSCA Notification of Export declarations were prepared.

SNL/CA personnel track disposal of TSCA materials that are not otherwise captured as RCRA or California toxic hazardous waste. These materials include asbestos and polychlorinated biphenyls (PCBs). The majority of TSCA waste generated onsite is asbestos from abatement activities. Only small quantities of PCB wastes are generated at SNL/CA, consisting of light ballasts that are not specifically marked as PCB-free.

\subsubsection{Federal Insecticide, Fungicide, and Rodenticide Act}

The Federal Insecticide, Fungicide, and Rodenticide Act (FIFRA) restricts the registration, sale, use, and disposal of pesticides (includes herbicides, insecticides, fungicides, and rodenticides) (7 USC $\S 136$ ). Activities at SNL/CA that fall under the provisions of FIFRA include the storage and use of pesticides, and disposal of pesticide containers. Pesticide handling and storage follows a site-specific standard operating procedure that includes provisions for training, use of personal protective equipment, proper handling following manufacturers guidelines, secondary containment during storage, and disposal of product and containers (SNL/CA 2009). Pesticide use at SNL/CA is overseen by a certified pesticide applicator.

\subsection{Pollution Prevention and Waste Minimization}

Pollution prevention concepts first appeared in RCRA. An expressed concern was to minimize the generation of hazardous waste through process substitution, materials recovery, recycling, reuse, and treatment. RCRA established the reduction or elimination of hazardous waste as national policy, and required that hazardous waste generators and RCRA permit holders have a program in place to minimize waste. SNL/CA personnel are required to report waste generation and recycling information yearly to DOE. To meet this requirement, the Annual Pollution Prevention Tracking Report was submitted to DOE on December 1, 2011 (SNL/CA 2011b). Additionally, SNL/CA's Waste Minimization Certificate required by the Hazardous Waste Storage Facility Part B Permit was submitted to the California Department of Toxic Substances Control (DTSC) prior to the March deadline. 


\subsubsection{Pollution Prevention Goals of Site Sustainability Plan}

The Sandia Site Sustainability Plan establishes a commitment to meet pollution prevention goals identified in DOE's Strategic Sustainability Performance Plan and executive order 13514. In 2011, SNL/CA continued to implement site-specific activities to support these goals through:

$>$ recycling of 21 solid waste streams;

$>$ recycling of construction debris;

$>$ chemical exchange;

$>$ awareness campaigns targeting paper use;

$>$ chemical acquisition program that encourages purchasing only the quantity needed;

$>$ management of batteries as universal waste; and

$>$ reapplication of equipment and supplies.

\section{P2 Goals}

$>$ Diversion of solid waste and demolition / construction debris from landfill disposal

$>$ Prevent or reduce pollution at the source, whenever feasible

$>$ Recycle, whenever feasible

$>$ Treat pollution that cannot be reduced or recycled, in an environmentally safe manner, whenever feasible

$>$ Release or dispose only as a last resort

In 2011, SNL/CA personnel reported pollution prevention and waste minimization data to the corporate Site Sustainability Plan team on November 30, 2011 for submittal to NNSA/SSO on December 7, 2011. Additional information about pollution prevention activities is provided in Chapter 4.

\subsubsection{Hazardous Waste Source Reduction and Management Review Act}

The California Hazardous Waste Source Reduction and Management Review Act of 1989, (Senate Bill 14), requires hazardous waste generators to consider source reduction as the preferred method of managing hazardous waste. Under this act, facilities that generate more than 12,000 kilograms $(\mathrm{kg})$ of hazardous waste or $12 \mathrm{~kg}$ of extremely hazardous waste annually are required to conduct source reduction planning.

Under an agreement between DOE and DTSC, all of DOE's California sites are considered one waste generator, rather than individual DOE facilities. Every four years, SNL/CA personnel complete a Source Reduction and Evaluation Review and Plan in cooperation with the other three DOE sites in California: Lawrence Livermore National Laboratory (LLNL); Lawrence Berkeley National Laboratory; and Stanford Linear Accelerator Center. The most recent plan was submitted to DTSC on August 31, 2011 and provided information for calendar year 2010. The plan also identifies waste reduction opportunities for any waste stream that is over five percent of a site's total routine regulated waste. The next plan, which will include information from calendar year 2014, will be prepared in 2015.

\subsubsection{Pollution Prevention Act}

The Pollution Prevention Act of 1990 declares, as national policy, that pollution should be prevented or reduced at the source (42 USC $\S 13101$ et. seq.). Facilities that meet the 
reporting requirements under EPCRA, Section 313 are also required to file a toxic chemical source reduction and recycling report. The Section 313 report for 2011 (for lead only) will include source reduction and recycling information to meet this requirement. The report is due annually on July 1. See Section 3.6.1 for additional information on EPCRA reporting requirements.

\subsection{Hazardous Waste}

\subsubsection{Federal Facility Compliance Act}

The Federal Facility Compliance Act waives sovereign immunity with respect to RCRA for federal facilities (42 USC $\S 6961$ ). The act gives EPA, and authorized states, authority to conduct annual inspections of federal facilities and establishes requirements for management of hazardous/mixed waste.

SNL/CA is not subject to a site-specific federal facility compliance agreement for mixed waste. The site does not possess or store any legacy mixed waste. All mixed waste generated at SNL/CA during 2011 was appropriately managed under the site's RCRA Hazardous Waste Facility Permit.

\subsubsection{Resource Conservation and Recovery Act}

RCRA regulates the generation, transportation, treatment, storage, and disposal of hazardous chemical waste, non-hazardous solid waste, and hazardous or petroleum products stored in USTs (42 USC $\$ 6901$ et. seq.). The State of California has authority from the EPA to implement RCRA. The DTSC administers most aspects of RCRA in the state, and is the regulating authority for hazardous waste operations at SNL/CA, including the hazardous component of radioactive mixed waste.

A Hazardous Waste Treatment and Storage Facility is operated at SNL/CA under a RCRA Hazardous Waste Facility Permit issued by DTSC on March 30, 2004. The permit is effective through March 2014 and allows for storage and treatment of hazardous waste.

By definition, SNL/CA is a large quantity generator of RCRA waste. As such, site personnel are required under RCRA standards and implementing regulations (40 CFR 262.41) to submit a biennial report to EPA on even numbered years.

During 2011, SNL/CA received two notices of violation related to RCRA. See Section 3.12 for information about these violations.

\subsubsection{California Hazardous Waste Control Law}

The Hazardous Waste Control Law (California Health and Safety Code $\$ 25100$ et. seq.) provides a separate regulatory framework for hazardous waste management in California. The state law incorporates all RCRA requirements and imposes additional requirements that are broader and more comprehensive than the federal system. Under the California law, additional waste materials (e.g., oils, metals, asbestos) or activities (e.g., treatment) are 
regulated as hazardous. State standards are incorporated into SNL/CA's Waste Management Program so that California regulated waste is managed as hazardous waste in compliance with state requirements.

The California Environmental Health Standards for Management of Hazardous Waste (22 CCR, Division 4.5) require all permitted hazardous waste facilities to submit an annual facility report to DTSC. Annual facility reports provide information about the quantity of RCRA and California designated hazardous waste generated and stored at SNL/CA, and the quantity of waste shipped from the site.

SNL/CA personnel submit an annual facility report to DTSC either in the form of the federal Biennial Report or the California Annual Facility Report, or both if requested by DTSC.

\subsubsection{Medical Waste Management Act}

The California Medical Waste Management Act (California Health and Safety Code, Division 104, Part 14, $\S \S 117600-118360$ ) provides for regulation of medical waste generators, transporters, and treatment facilities. The Alameda County Department of Environmental Health is the regulating authority for medical waste generated at SNL/CA. SNL/CA has two facilities identified as small quantity generators of medical waste, one with limited onsite treatment and one without onsite treatment.

\subsection{Radiation Protection}

\subsubsection{Atomic Energy Act}

The purpose of the Atomic Energy Act is to assure the proper management of nuclear materials and radioactive waste (42 USC $\S 2011$ et. seq.). The act allows DOE to set radiation protection standards to control exposure to the public and the environment that may result from operations at DOE facilities. DOE sets these standards through department directives. Operations at SNL/CA are subject to the requirements established in DOE Order 435.1, Radioactive Waste Management (DOE 2001) and DOE Order 458.1, Radiation Protection of the Public and the Environment (DOE 2011c).

\subsubsection{DOE Order 435.1, Radioactive Waste Management}

DOE Order 435.1 establishes requirements to manage radioactive waste in a manner that protects the environment, and worker and public health and safety. Under this order, DOE contractor operated facilities are required to plan, document, execute, and evaluate the management of radioactive waste. Requirements of Order 435.1 are incorporated into the $\mathrm{SNL} / \mathrm{CA}$ radioactive waste management element of the Waste Management Program. The program includes certification and characterization of waste; provisions for inspections and audits; training requirements; and operating procedures for handling, storing, packaging, shipping, and offsite disposal of radioactive waste.

SNL/CA operations generate low-level radioactive waste and low-level mixed waste. No transuranic or high-level radioactive waste is generated by SNL/CA operations. Low-level 
radioactive and mixed wastes are stored prior to shipment in the Radioactive Waste Treatment and Storage Facility. Low-level radioactive waste is shipped offsite to SNL/NM with final land disposal at the Nevada Test Site. Mixed Waste is managed under federal RCRA and state waste regulations and shipped offsite for treatment and disposal via commercial disposal facilities.

\subsubsection{DOE Order 458.1, Radiation Protection of the Public and the Environment}

DOE Order 458.1 sets radiation protection standards for DOE operations so that radiation exposures to members of the public and the environment are as low as reasonably achievable (ALARA) and maintained within established limits of the order. Table 3-2 provides a summary of SNL/CA compliance with this order in 2011.

Table 3-2 Order 458.1 Compliance Summary, 2011

\section{Order 458.1 Requirement}

Develop and implement an environmental

radiological protection program

\section{SNL/CA 2011 Summary}

In December 2011, Sandia completed an evaluation of DOE Order 458.1 against our current processes and procedures. Modifications to the existing SNL/CA environmental radiological protection program that has been in place for more than 30 years, were not needed.

Control exposure to the public such that annual exposure will not exceed a total effective dose of $100 \mathrm{mrem}$, an equivalent dose to the lens of the eye of $1500 \mathrm{mrem}$, or an equivalent dose to the skin or extremities of $5000 \mathrm{mrem}$.

There were no radionuclide emissions in 2011.

The average annual gamma radiation measurement at the site perimeter in 2011 was 62.9 mrem or $8.5 \mathrm{mrem}$ more than the local background does of $54.4 \mathrm{mrem}$. The difference between the perimeter and distant locations appears to be from the first quarter of 2011. Measurements taken at SNL/CA's thermoluminescent dosimeter stations were higher than usual during this time. However, these higher measurements did not continue during the remainder of the year. Although there is no explanation for this phenomenon at this time, the higher first quarter measurement was most likely the result of a sampling or measurement artifact.

Request authorization for temporary dose limits.

There were no special circumstances in 2011 requiring temporary dose limits.

Adopt ALARA exposures.

ALARA is incorporated into environment, safety, and health (ES\&H) policy, processes, and procedures.

Demonstrate compliance with public dose limits from the air pathway.
NESHAPS dose calculations are completed as needed. There were no airborne radionuclide emission sources in 2011; therefore, there is no monitoring data available for dose evaluations. 


\begin{tabular}{|c|c|}
\hline Order 458.1 Requirement & SNL/CA 2011 Summary \\
\hline Control airborne radioactive effluents. & $\begin{array}{l}\text { ES\&H processes, procedures, and management } \\
\text { systems are incorporated into site operations to } \\
\text { ensure that projects are reviewed for potential } \\
\text { airborne effluents and dose calculations are } \\
\text { performed, as needed. }\end{array}$ \\
\hline Control release of liquid radioactive discharges. & $\begin{array}{l}\text { No intentional discharges of liquid radioactive } \\
\text { wastes to the environment occur onsite. No } \\
\text { accidental releases of liquid radioactive waste } \\
\text { occurred in } 2011 \text {. Radioactive releases to the } \\
\text { sanitary sewer above DOE O } 458.1 \text { guidelines are } \\
\text { not allowed at SNL/CA. ES\&H processes, } \\
\text { procedures, and management systems are } \\
\text { incorporated into site operations to ensure proper } \\
\text { handling and disposal of radioactive materials. }\end{array}$ \\
\hline Control radioactive waste. & $\begin{array}{l}\text { SNL/CA generates only low-level radioactive } \\
\text { waste. ES\&H processes, procedures, and } \\
\text { management systems are incorporated into site } \\
\text { operations to ensure proper handling and disposal } \\
\text { of radioactive waste. }\end{array}$ \\
\hline Protect drinking water and groundwater. & $\begin{array}{l}\text { ES\&H processes, procedures, and management } \\
\text { systems are incorporated into site operations to } \\
\text { ensure proper handling, and disposal of } \\
\text { radioactive materials offsite at approved facilities. } \\
\text { Routine analyses of groundwater and storm water } \\
\text { samples includes radioactive constituents. }\end{array}$ \\
\hline Protect biota. & $\begin{array}{l}\text { ES\&H processes, procedures, and management } \\
\text { systems are incorporated into site operations to } \\
\text { ensure proper handling, and disposal of } \\
\text { radioactive materials offsite at approved facilities. } \\
\text { SNL/CA is not required to monitor biota. }\end{array}$ \\
\hline $\begin{array}{l}\text { Control the release of property with residual } \\
\text { radioactivity. }\end{array}$ & $\begin{array}{l}\text { SNL/CA does not currently operate any areas } \\
\text { where property clearance surveys are required. } \\
\text { However, if this were to change, the appropriate } \\
\text { surveys and documentation would occur. } \\
\text { SNL/CA does not release any property to the } \\
\text { public with residual radioactivity above } \\
\text { authorized limits. Excess property of this type is } \\
\text { either transferred to other DOE facilities for reuse } \\
\text { or transferred to Waste Management for disposal. }\end{array}$ \\
\hline Retain records. & $\begin{array}{l}\text { ES\&H processes and procedures are in place to } \\
\text { manage records. }\end{array}$ \\
\hline
\end{tabular}




\subsection{Water Quality and Protection}

SNL/CA is subject to the requirements of the Clean Water Act and equivalent California statutes. SNL/CA does not operate a public water system, and is not involved in any environmental restoration activities for which Safe Drinking Water Act standards are being applied.

Drinking water at SNL/CA is purchased through LLNL and obtained from the San Francisco Water District or the Alameda County Flood Control and Water Conservation District, Zone 7. The San Francisco Water District and Zone 7 are responsible for monitoring the quality of the incoming water. SNL/CA is not required to treat or sample the drinking water. LLNL maintains the primary drinking water distribution system that feeds to SNL/CA and screens for water quality (SNL/CA 2002).

\subsubsection{Clean Water Act}

The Clean Water Act regulates all direct discharges into navigable waters of the United States (U.S.) (33 USC § 1251). Direct discharges to waters of the U.S. require permits issued under the National Pollutant Discharge Elimination System (NPDES). In California, the State Water Resources Control Board has authority from EPA to implement the Clean Water Act. Federal permitting requirements are included in Waste Discharge Requirements issued by Regional Water Quality Control Boards.

\section{Wastewater Discharge}

Wastewater generated at SNL/CA is discharged to the City of Livermore Water Reclamation Plant, a publicly owned treatment works (POTW). The Livermore POTW maintains an NPDES permit, and then regulates industry discharges into their sewer system. A Wastewater Discharge Permit issued by the Livermore POTW regulates SNL/CA's wastewater discharges. The permit is updated annually and includes discharge limits for the site sanitary sewer outfall and for processes subject to EPA pretreatment standards. There were no permit exceedances in 2011 at the sanitary sewer outfall. For routine wastewater monitoring information, see Section 5.2.1.

SNL/CA has three categorical processes that are subject to EPA's pretreatment standards: two metal finishing operations, and a semiconductor manufacturing operation. The two metal finishing operations are closed-loop processes and do not discharge any effluents. Wastewater generated from the semiconductor manufacturing process is sampled and monitored as part of the Environmental Monitoring Program. There were no exceedances of the discharge limits from this source during 2011.

\section{Storm Water Discharge}

General storm water discharges at SNL/CA are covered under the State of California NPDES General Permit for Storm Water Discharge Associated with Industrial Activities (General 
Industrial Permit) (California Water Resources Control Board 1997). The General Industrial Permit requires SNL/CA to implement a storm water pollution prevention plan. The SNL/CA plan describes the rationale for monitoring discharge locations and identifies best management practices for reducing pollutant contact with storm water.

The current General Industrial Permit does not contain numeric limits or standards for storm water discharges. However, the most current draft of the new General Industrial Permit does identify limits. The new General Industrial Permit is expected to be adopted sometime in 2012. When the new permit becomes effective, Sandia personnel will compare storm water analytical results to the standards as required by the General Industrial Permit.

SNL/CA's storm water management program also incorporates the six minimum control measures required by the California Small Municipal Separate Storm Sewer System (MS4) General Permit. The MS4 General Permit was adopted in 2003 to meet EPA Phase II storm water regulations. Although the MS4 General Permit is not yet a regulatory requirement for SNL/CA, site personnel anticipate that the site will be regulated as a non-traditional small MS4 when notification is provided by the regulating agency. The Small MS4 General Permit will require full implementation of a Storm Water Management Program, addressing the six minimum control measures, within five years of notification / designation as a non-traditional Small MS4. In addition to proactively incorporating the minimum control measures into the existing storm water management program, site personnel completed a five-year implementation schedule in 2008.

In 2011, SNL/CA personnel visually monitored 21 storm water discharge locations and sampled eight of nine locations. One sampling location did not have sufficient runoff during the year; consequently, this location could not be sampled. The result of monitoring and sampling activities conducted in 2011 did not identify any issues of concern. Section 5.1 presents a summary of 2011 results.

Under Section 438 of the Energy Independence and Security Act of 2007, federal agencies have requirements to reduce storm water runoff from development and redevelopment projects. In 2011, SNL/CA installed one retention basin with a capacity of 780 cubic feet to meet these requirements.

\subsection{Audits, Assessments, and Inspections}

Table 3-3 provides a list of environmental program audits, assessments, and/or inspections conducted at SNL/CA during 2011. 
Table 3-3 SNL/CA Audits, Assessments, and Inspections, 2011

\begin{tabular}{|c|c|c|c|}
\hline Title & Area of Focus & Date Conducted & Results \\
\hline Alameda County Inspection & $\begin{array}{l}\text { Erosion at the Navy Landfill } \\
\text { site }\end{array}$ & October 25,2011 & $\begin{array}{l}\text { Two non- } \\
\text { conformances }\end{array}$ \\
\hline $\begin{array}{l}\text { City of Livermore, Water } \\
\text { Resources Division } \\
\text { Inspections }\end{array}$ & $\begin{array}{l}\text { Wastewater discharges and } \\
\text { categorical process } \\
\text { laboratories }\end{array}$ & September 20, 2011 & No violations \\
\hline $\begin{array}{l}\text { Third Party Environmental } \\
\text { Management System (EMS) } \\
\text { Surveillance Audit (NSF- } \\
\text { ISR) }\end{array}$ & $\begin{array}{l}\text { Conformance with the ISO } \\
\text { 14001:2004 EMS standard }\end{array}$ & June 2011 & $\begin{array}{l}\text { One major and two } \\
\text { minor non- } \\
\text { conformances }\end{array}$ \\
\hline California EPA - DTSC & Waste management & May 9, 2011 & One violation \\
\hline California EPA - DTSC & Waste management & $\begin{array}{l}\text { December } 15 \text { and } 20, \\
2011\end{array}$ & No violations \\
\hline Alameda County Inspection & Underground Storage Tanks & March 11, 2011 & $\begin{array}{l}\text { Three minor } \\
\text { violations }\end{array}$ \\
\hline Alameda County Inspection & Waste Tire Manifest program & October 5, 2011 & No violations \\
\hline $\begin{array}{l}\text { Livermore-Pleasanton Fire } \\
\text { Department Inspection }\end{array}$ & $\begin{array}{l}\text { Hazardous waste } \\
\text { management }\end{array}$ & November 2, 2011 & $\begin{array}{l}\text { One opportunity for } \\
\text { improvement }\end{array}$ \\
\hline Alameda County Inspection & Medical waste & November 3, 2011 & No violations \\
\hline
\end{tabular}

\subsection{Environmental Occurrences}

An environmental occurrence is an event that meets the occurrence criteria established in DOE Order 232.2. While regulatory violations often meet the DOE criteria for reporting and managing as environmental occurrences, not all violations qualify as occurrences. For example, the three minor violations noted in Table 3-3 related to underground storage tanks did not meet the DOE occurrence criteria; consequently, these minor violations are not addressed in this section. These minor violations are addressed in Section 3.6.3.

In 2011, there were two environmental occurrences at SNL/CA. The first occurrence was a result of additional findings associated with an August 9, 2010 Notice of Violation related to hazardous waste treatment and permitting requirements. An addendum to the 2010 Notice of Violation was issued on January 7, 2011 by Alameda County Environmental Health. The addendum NOV cited two hazardous waste treatment and permitting deficiencies. Alameda County Environmental Health sought enforcement action for these two hazardous waste treatment processes. Sandia has settled with Alameda County and both operations are now properly permitted.

The second occurrence resulted from a DTSC annual inspection of the permitted waste facility. A minor violation for an inaccurate container inventory record was issued on May 9, 2011. The violation was corrected immediately at the time of the inspection.

\subsection{Permits}

Environmental permits and clean-up orders held by SNL/CA are listed in Table 3-4. Additional information is provided in previous sections under the related program or regulation. 
Table 3-4 SNL/CA Environmental Permits and Orders, 2011

\begin{tabular}{|c|c|c|c|c|}
\hline Type & Description & Effective Date & $\begin{array}{l}\text { Statute / } \\
\text { Regulation }\end{array}$ & Issuing Agency \\
\hline $\begin{array}{l}\text { Environmental } \\
\text { restoration }\end{array}$ & $\begin{array}{l}\text { Site Clean-up Order No. } \\
89-184\end{array}$ & $\begin{array}{l}\text { December } 1989 \text { (no } \\
\text { expiration date) }\end{array}$ & $\begin{array}{l}\text { California Water } \\
\text { Code }\end{array}$ & $\begin{array}{l}\text { Regional Water Quality Control } \\
\text { Board, San Francisco Bay }\end{array}$ \\
\hline $\begin{array}{l}\text { Hazardous } \\
\text { materials }\end{array}$ & $\begin{array}{l}\text { Business Plan Permit to } \\
\text { Operate }\end{array}$ & $\begin{array}{l}\text { January } 1- \\
\text { December } 31 \text {, } \\
\text { annually }\end{array}$ & $\begin{array}{l}\text { California Health } \\
\text { and Safety Code }\end{array}$ & $\begin{array}{l}\text { Livermore-Pleasanton Fire } \\
\text { Department }\end{array}$ \\
\hline $\begin{array}{l}\text { Hazardous } \\
\text { waste }\end{array}$ & $\begin{array}{l}\text { RCRA Hazardous } \\
\text { Waste Facility Permit }\end{array}$ & $\begin{array}{l}\text { March } 2004 \text { - March } \\
2014\end{array}$ & $\begin{array}{l}\text { Resource } \\
\text { Conservation and } \\
\text { Recovery Act }\end{array}$ & $\begin{array}{l}\text { California Department of Toxic } \\
\text { Substances Control }\end{array}$ \\
\hline $\begin{array}{l}\text { Hazardous } \\
\text { waste }\end{array}$ & Permit by Rule & $\begin{array}{l}\text { January } 1- \\
\text { December } 31 \text {, } \\
\text { annually }\end{array}$ & $\begin{array}{l}\text { California Health } \\
\text { and Safety Code }\end{array}$ & $\begin{array}{l}\text { Livermore-Pleasanton Fire } \\
\text { Department }\end{array}$ \\
\hline $\begin{array}{l}\text { Hazardous } \\
\text { waste }\end{array}$ & $\begin{array}{l}\text { Conditionally } \\
\text { Authorized Permit to } \\
\text { Operate }\end{array}$ & $\begin{array}{l}\text { January } 1- \\
\text { December } 31, \\
\text { annually }\end{array}$ & $\begin{array}{l}\text { California Health } \\
\text { and Safety Code }\end{array}$ & $\begin{array}{l}\text { Livermore-Pleasanton Fire } \\
\text { Department }\end{array}$ \\
\hline Medical waste & $\begin{array}{l}\text { Small Quantity } \\
\text { Generator with Onsite } \\
\text { Treatment }\end{array}$ & $\begin{array}{l}\text { August } 9 \text { - August } \\
8 \text {, annually }\end{array}$ & $\begin{array}{l}\text { California Health } \\
\text { and Safety Code }\end{array}$ & $\begin{array}{l}\text { Alameda County Dept. of } \\
\text { Environmental Health }\end{array}$ \\
\hline Medical waste & $\begin{array}{l}\text { Small Quantity } \\
\text { Generator without } \\
\text { Onsite Treatment }\end{array}$ & $\begin{array}{l}\text { April } 11 \text { - April 10, } \\
\text { annually }\end{array}$ & $\begin{array}{l}\text { California Health } \\
\text { and Safety Code }\end{array}$ & $\begin{array}{l}\text { Alameda County Dept. of } \\
\text { Environmental Health }\end{array}$ \\
\hline Wastewater & $\begin{array}{l}\text { Wastewater Discharge } \\
\text { Permit }\end{array}$ & $\begin{array}{l}\text { August } 4 \text { - August } 3 \text {, } \\
\text { annually }\end{array}$ & Clean Water Act & $\begin{array}{l}\text { City of Livermore Water } \\
\text { Reclamation Plant }\end{array}$ \\
\hline Storm water & $\begin{array}{l}\text { State of California } \\
\text { General Industrial } \\
\text { Permit }\end{array}$ & $\begin{array}{l}\text { July } 1997 \text { - July } \\
2002^{\mathrm{a}}\end{array}$ & Clean Water Act & $\begin{array}{l}\text { California Water Resources } \\
\text { Control Board }\end{array}$ \\
\hline $\begin{array}{l}\text { Jurisdictional } \\
\text { waters of the } \\
\text { U.S. }\end{array}$ & $\begin{array}{l}\text { Channel Improvements } \\
\text { under the Arroyo Seco } \\
\text { Improvement Program }\end{array}$ & $\begin{array}{l}\text { September } 25,2008- \\
\text { July } 11,2018\end{array}$ & Clean Water Act & Army Corp of Engineers \\
\hline $\begin{array}{l}\text { Underground } \\
\text { storage tank }\end{array}$ & Permit to Operate & $\begin{array}{l}\text { January } 1- \\
\text { December } 31 \text {, } \\
\text { annually }\end{array}$ & $\begin{array}{l}\text { Resource } \\
\text { Conservation and } \\
\text { Recovery Act and } \\
\text { California Health } \\
\text { and Safety Code }\end{array}$ & $\begin{array}{l}\text { Livermore-Pleasanton Fire } \\
\text { Department }\end{array}$ \\
\hline $\begin{array}{l}\text { Aboveground } \\
\text { storage tanks }\end{array}$ & Storage statement & $\begin{array}{l}\text { January } 1- \\
\text { December } 31 \text {, } \\
\text { biannually } \\
\end{array}$ & $\begin{array}{l}\text { Aboveground } \\
\text { Petroleum } \\
\text { Storage Act } \\
\end{array}$ & $\begin{array}{l}\text { Livermore-Pleasanton Fire } \\
\text { Department }\end{array}$ \\
\hline Air & $\begin{array}{l}\text { Permit to Operate } 13 \\
\text { emission sources }^{\mathrm{b}}\end{array}$ & $\begin{array}{l}\text { July } 1 \text { - June } 30 \text {, } \\
\text { annually }\end{array}$ & Clean Air Act & $\begin{array}{l}\text { Bay Area Air Quality } \\
\text { Management District }\end{array}$ \\
\hline $\begin{array}{l}\text { Universal } \\
\text { waste }\end{array}$ & Generator statement & February 1, 2006 & $\begin{array}{l}\text { California } \\
\text { Electronic Waste } \\
\text { Recycling Act }\end{array}$ & $\begin{array}{l}\text { California Department of Toxic } \\
\text { Substances Control }\end{array}$ \\
\hline \multicolumn{5}{|c|}{$\begin{array}{l}\text { a The current General Industrial Permit continues in effect until a new permit is issued by the State Water Resources Control } \\
\text { Board (Permit Section C.18). When the renewal process is complete and a new General Industrial Permit is issued by the } \\
\text { State, SNL/CA will apply for coverage under the new permit. } \\
\text { bEmission sources include } 1 \text { non-retail gasoline dispensing facility, } 5 \text { miscellaneous sources (decontamination sink, waste } \\
\text { compactor, drum crusher, and } 2 \text { site-wide sources for solvent emissions), } 6 \text { emergency generators, and } 1 \text { portable generator } \\
\text { with discretionary usage. }\end{array}$} \\
\hline
\end{tabular}




\section{Environmental Management}

Sandia National Laboratories, California (SNL/CA) management is firmly committed to sound environmental stewardship practices as well as compliance with environmental requirements. Site management meets this commitment through an environmental management system (EMS) that integrates traditional environmental program elements with objectives for improving the environmental footprint of site operations. The site's EMS program is dynamic, encompassing an annual cycle of planning, implementing, assessing, and improving operations in support of site-specific environmental goals.

SNL/CA's EMS program conforms to the international standard for environmental management systems, ISO 14001. SNL/CA initially received ISO 14001:2004 registration on September 25, 2006. In June 2009, the site underwent a successful audit to the ISO 14001 standard and received reregistration for an additional 3-year period on July 5, 2009. To ensure that the site maintains conformance with the standard, surveillance audits are conducted periodically. The most recent surveillance audit of the SNL/CA EMS program was conducted in June 2011, resulting in continuation of certification, two minor nonconformances, and one major nonconformance. The major non-

SNL/CA Environment, Safety, and Health (ES\&H) Standard of Performance

SNL/CA is firmly committed to meeting all corporate and regulatory ES\&H policies and requirements that apply to its operations. The application of compliant ES\&H principles and practices is considered a fundamental element of everyone's work assignment.

In this regard, SNL/CA commits to:

$>\quad$ Nurture a safety and health conscious work ethic and culture. We will all assume responsibility for creating and maintaining a worksite, as well as performing our work, in a manner that respects and supports the safety and health of every individual. SNL/CA believes that all accidents are preventable. We will all strive to create a workplace that is free of accidents and injuries.

$>\quad$ Be a responsible steward of the environmental resources in our care. We will integrate environmental risk assessment, planning and impact mitigation into every aspect of our work. SNL/CA programs, operations, processes, and facilities will be planned and managed such that they support environmental objectives and targets to minimize the creation of waste, pollution, and adverse impact on the public and the environment. SNL/CA will remain committed to an efficient and effective Environmental Management System as part of the laboratory's Integrated Safety Management System.

$>$ Comply with all applicable laws, regulations and permits. Compliance with the letter and the spirit of ES\&H laws and regulations is viewed as the minimum acceptable standard. When necessary and appropriate we will go beyond legal mandates in order to implement more effective approaches and to nurture a positive and learning ES\&H culture. SNL/CA is committed to continual improvement in all aspects of our environment, safety, and health performance and commits to establish performance indicators to guide these efforts and measure our progress.

conformance resulted from a repeat minor non-conformance related to the provision of EMS awareness information to site visitors. 


\subsection{EMS Elements}

SNL/CA's EMS Program encompasses the seventeen elements of an effective EMS as identified in the ISO 14001:2004 standard. Table 4-1 identifies the EMS elements and summarizes the methods, tools, and programs implemented in support of each.

Table 4-1 Elements of the SNL/CA EMS Program

\begin{tabular}{|c|c|}
\hline EMS Element & Implementation Summary \\
\hline $\begin{array}{c}\text { Environmental } \\
\text { policy }\end{array}$ & $\begin{array}{l}\text { SNL/CA personnel operate under a site-specific ES\&H standard of performance that } \\
\text { reinforces individual accountability, environmental stewardship, and compliance. SNL/CA } \\
\text { management stresses the need to move beyond compliance to nurturing of a positive ES\&H } \\
\text { culture at all levels of the workforce. }\end{array}$ \\
\hline $\begin{array}{l}\text { Environmental } \\
\text { aspects }\end{array}$ & $\begin{array}{l}\text { Environmental aspects are elements of operations and activities that can interact with the } \\
\text { environment, such as water discharges. SNL/CA personnel evaluate site activities and } \\
\text { operations annually to ensure environmental aspects are up-to-date and accurate. From this } \\
\text { complete list (19 aspects), significant aspects are determined through a risk evaluation. For } \\
\text { 2011, SNL/CA's significant environmental aspects are water discharges, air emissions, land } \\
\text { use, general transportation, and hazardous waste. }\end{array}$ \\
\hline $\begin{array}{l}\text { Legal and other } \\
\text { requirements }\end{array}$ & $\begin{array}{l}\text { Sandia maintains a formal process for monitoring federal, state, and local government } \\
\text { publications for regulatory changes and issues applicable to Sandia operations. SNL/CA } \\
\text { environmental personnel augment this process by monitoring publications specific to } \\
\text { functional environmental program areas and through interaction with regulating agencies. } \\
\text { Environmental subject matter experts analyze all new requirements, and team with other site } \\
\text { personnel to achieve compliance. New requirements and modifications to environmental } \\
\text { programs are documented in annual program reports. }\end{array}$ \\
\hline $\begin{array}{c}\text { Objectives and } \\
\text { targets }\end{array}$ & $\begin{array}{l}\text { SNL/CA management maintains ten EMS objectives that support efforts to reduce potential } \\
\text { environmental risk and enhance environmental stewardship. Targets are evaluated and set } \\
\text { each year to support site objectives. SNL/CA's } 2011 \text { objectives are to: } \\
>\text { Demonstrate exceptional environmental performance and management. } \\
>\text { Minimize consumption (energy, water, non-renewable resources). } \\
\text { Minimize the production of waste (non-hazardous, hazardous, radiological, waste } \\
\text { water). } \\
>\text { Minimize air pollutant and greenhouse gas emissions. } \\
>\text { Preserve and, when possible, enhance the site's natural habitat. } \\
>\text { Maintain sewer effluent within regulatory discharge limits. } \\
>\text { Minimize the volume and pollution of storm water runoff and water discharges. } \\
>\text { Procure and use environmentally friendly products and materials. } \\
>\text { Minimize pollutants released to the ground or groundwater (spills, landscape } \\
\text { chemicals, metals, etc.). }\end{array}$ \\
\hline $\begin{array}{c}\text { Environmental } \\
\text { programs }\end{array}$ & $\begin{array}{l}\text { SNL/CA's EMS Program is supported by six functional environmental programs. } \\
\text { Air Quality } \\
\text { Environmental Monitoring } \\
\text { Environmental Planning } \\
\text { Chemical Management } \\
\text { Pollution Prevention and Waste Minimization } \\
\text { Waste Management }\end{array}$ \\
\hline
\end{tabular}




\begin{tabular}{|c|c|}
\hline EMS Element & Implementation Summary \\
\hline $\begin{array}{l}\text { Structure, } \\
\text { responsibilities, } \\
\text { and authorities }\end{array}$ & $\begin{array}{l}\text { SNL/CA's EMS Program is implemented through existing site management and } \\
\text { organizational structures. The site Vice President holds overall responsibility for success of } \\
\text { the EMS Program. Director and senior management personnel ensure availability of } \\
\text { resources. An environmental management representative and EMS core team are responsible } \\
\text { for day-to-day management of the program. All members of the workforce hold } \\
\text { responsibility and authority to implement EMS elements into their operations. }\end{array}$ \\
\hline $\begin{array}{l}\text { Competence, } \\
\text { training, and } \\
\text { awareness }\end{array}$ & $\begin{array}{l}\text { SNL/CA employs a variety of mechanisms to ensure that the site workforce and visitors } \\
\text { maintain the appropriate training and competence levels for their assignments, and to foster } \\
\text { awareness. These mechanisms include corporate training programs, site-specific training } \\
\text { programs, and activity-specific training programs. For contractor-directed activities that } \\
\text { occur on site, standard specifications are issued that identify training, credentials, and } \\
\text { certifications required for each project. }\end{array}$ \\
\hline Communication & $\begin{array}{l}\text { EMS Program staff communicates EMS information internally through project review } \\
\text { teams, publications, websites, briefings, assessments, and promotional information. } \\
\text { Information is communicated externally through publications, websites, SNL/CA's Public } \\
\text { and Media Relations Office, and regulatory-driven documents. }\end{array}$ \\
\hline $\begin{array}{c}\text { EMS } \\
\text { documentation }\end{array}$ & $\begin{array}{l}\text { EMS Program staff maintains an EMS Program Manual as the primary EMS document for } \\
\text { the site. General corporate and site policies, document systems, and databases provide } \\
\text { supporting documentation for the EMS Program. }\end{array}$ \\
\hline $\begin{array}{l}\text { Document } \\
\text { control }\end{array}$ & $\begin{array}{l}\text { At SNL/CA, document control is accomplished with electronic documents that are available } \\
\text { in online databases. If paper copies of technical work documents are maintained at the point } \\
\text { of use, department managers ensure that a process is in place to keep them up to date. } \\
\text { Permits and other regulatory documents of external origin are typically marked as valid for a } \\
\text { specified period and controlled by limited distribution coordinated by environmental } \\
\text { program leads. }\end{array}$ \\
\hline $\begin{array}{l}\text { Operational } \\
\text { controls }\end{array}$ & $\begin{array}{l}\text { Sandia employs an integrated system to address ES\&H concerns associated with site } \\
\text { operations. This integrated system provides the framework for planning work, evaluating } \\
\text { hazards, identifying controls, conducting work, and improving work processes. Unique to } \\
\text { SNL/CA, the ES\&H, Facilities, and Security Interdisciplinary Team supports integrated } \\
\text { safety and environmental management to ensure requirements and controls are identified } \\
\text { during project planning. Typical operational controls used at SNL/CA include technical } \\
\text { work documents, environmental permits and compliance documents, contract specifications, } \\
\text { and a variety of engineered controls. }\end{array}$ \\
\hline $\begin{array}{l}\text { Emergency } \\
\text { preparedness } \\
\text { and response }\end{array}$ & $\begin{array}{l}\text { An established Emergency Management Program that maintains responsibility for } \\
\text { preparedness and response supports SNL/CA's EMS Program. Emergency Management } \\
\text { conducts routine drills and communication tests, and annually conducts site-wide training } \\
\text { exercises. Environmental representatives are active members of emergency response teams } \\
\text { to ensure that potential environmental risks are managed and mitigated appropriately. }\end{array}$ \\
\hline $\begin{array}{l}\text { Monitoring and } \\
\text { measurement }\end{array}$ & $\begin{array}{l}\text { Each of the six SNL/CA functional environmental program leads monitor and measure the } \\
\text { key characteristics of site operations that can affect the environment. Data collected supports } \\
\text { compliance requirements as well as assessment of the site's overall progress in meeting } \\
\text { EMS objectives. Monitoring data and metrics are available to the public in annual } \\
\text { environmental reports. }\end{array}$ \\
\hline $\begin{array}{l}\text { Evaluating } \\
\text { compliance }\end{array}$ & $\begin{array}{l}\text { Environmental subject matter experts evaluate compliance with all environmental } \\
\text { requirements through the Interdisciplinary Team process, self-assessments, and audits. }\end{array}$ \\
\hline $\begin{array}{l}\text { Nonconformity, } \\
\text { corrective, and } \\
\text { preventive } \\
\text { action }\end{array}$ & $\begin{array}{l}\text { EMS Program staff documents, tracks, and verifies corrective and preventive actions with } \\
\text { electronic assessment tracking and corrective action systems. The EMS Core Team also } \\
\text { established a procedure for validating the effectiveness of select actions and to reduce the } \\
\text { potential for recurrence of significant nonconformities. }\end{array}$ \\
\hline Records & $\begin{array}{l}\text { All information created by conduct of Sandia operations is managed as a record. ES\&H } \\
\text { information created at SNL/CA is managed by the site ES\&H Records Center. }\end{array}$ \\
\hline $\begin{array}{l}\text { Management } \\
\text { review }\end{array}$ & $\begin{array}{l}\text { SNL/CA's top management team (VP and directors) review the EMS Program semi- } \\
\text { annually. In 2011, management reviews resulted in two recommendations related to } \\
\text { sustainable landscaping and community awareness. }\end{array}$ \\
\hline
\end{tabular}




\subsection{Environmental Performance}

SNL/CA's EMS Program staff measures the site's environmental performance by tracking progress towards achieving EMS objectives and corporate performance measures established jointly between Sandia and the National Nuclear Security Administration, Sandia Site Office (NNSA/SSO). The following diagrams and text summarize SNL/CA's performance in meeting the site's ten EMS objectives. One corporate measure applicable to SNL/CA is also addressed under Objective 1.

Although there is not a one-to-one correlation, many of SNL/CA's EMS objectives and targets also support the objectives of the corporate Site Sustainability Plan. The corporate Site Sustainability Plan objectives, in turn, support DOE's Strategic Sustainability Performance Plan goals. SNL/CA objectives and/or targets that support the broader corporate objectives and, consequently, DOE goals, are indicated with an SSP designator.

\section{Objective 1: Demonstrate exceptional environmental performance and management}

SNL/CA personnel track noncompliance with environmental requirements as a measure of our environmental management performance. Figure 4-1 shows the number of findings from third-party audits (includes DOE), notices of violation, and other environmental occurrences since 2000. The Sandia goal is zero findings and zero violations. SNL/CA operations received two notices of violation and three minor violations in 2011. As a routine element of the EMS Program, Sandia personnel identify and implement corrective and preventive actions in an effort to improve environmental performance and reach the Sandia goal of zero violations and zero findings.

This objective also supports a 2011 NNSA/SSO performance measure to maintain effective and efficient ES\&H systems. This performance measure is supported by maintaining ISO 14001:2004 registration of the site's EMS. By conforming to the ISO standard, sound environmental stewardship practices are integrated with regulatory compliance to reduce the site's environmental footprint. Sandia received a rating of "very good" for this performance measure. 


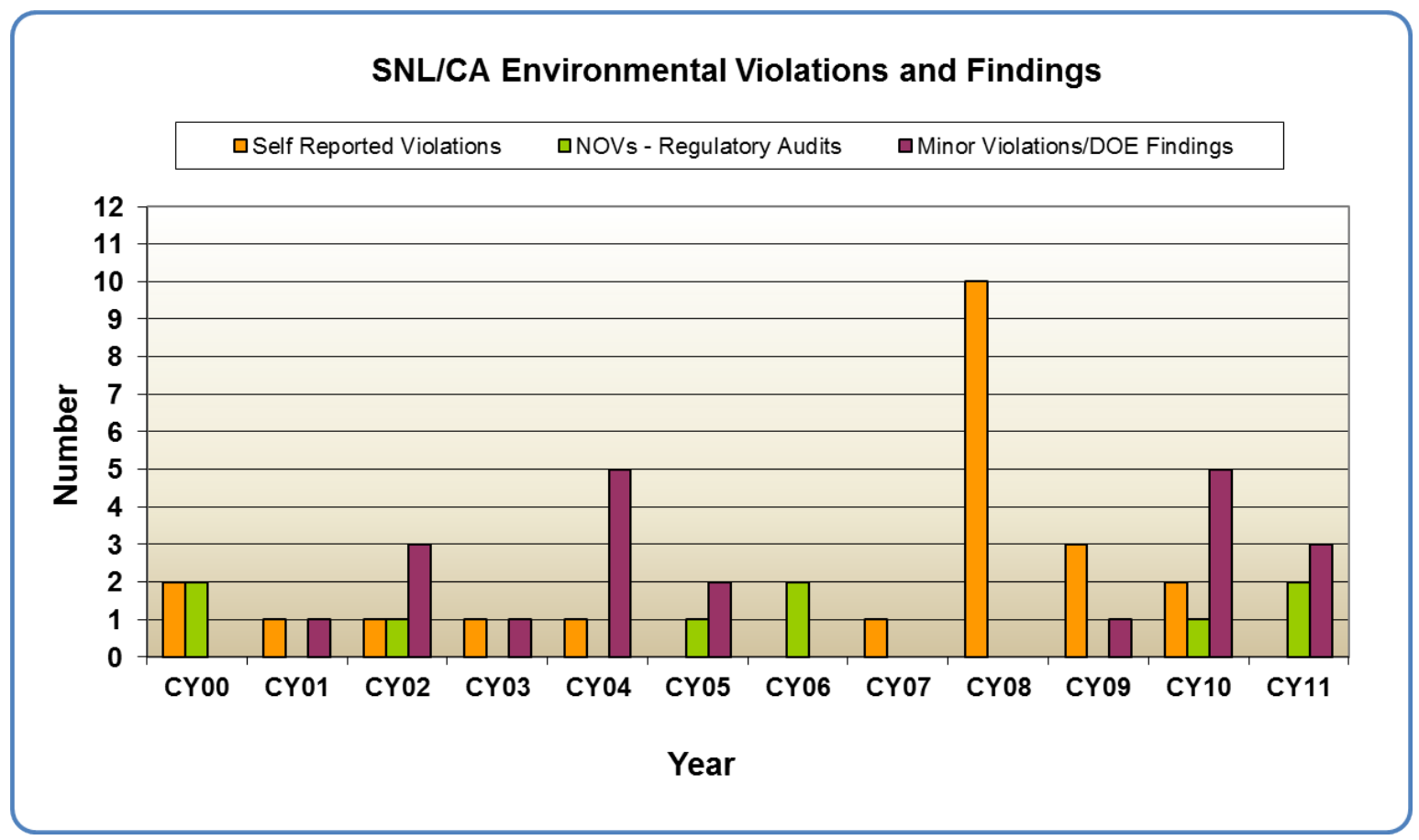

Figure 4-1 Measurement of Excellence in Environmental Management

\section{Hazardous Materials}

SNL/CA personnel also measure environmental performance by effective hazardous materials management. The overall goal of SNL/CA's EMS Program is protection of the environment from the negative effects of site activities including hazardous materials use. Central to this defense of the environment, is proper chemical inventory management. Rightsizing the inventory and minimizing toxicity is, therefore, key to environmentally friendly hazardous materials management. As shown in Figure 4-2 the number of hazardous materials containers peaked in 2003 and have been steadily declining since. Overall, the number of containers for higher toxicity materials (shown as NFPA Health $3 \& 4$ ) has also declined since 2003. These declines reduce the risk inherent to personnel and the environment from hazardous materials used and stored on site. 


\section{SNL/CA Chemical Inventory Container Count}

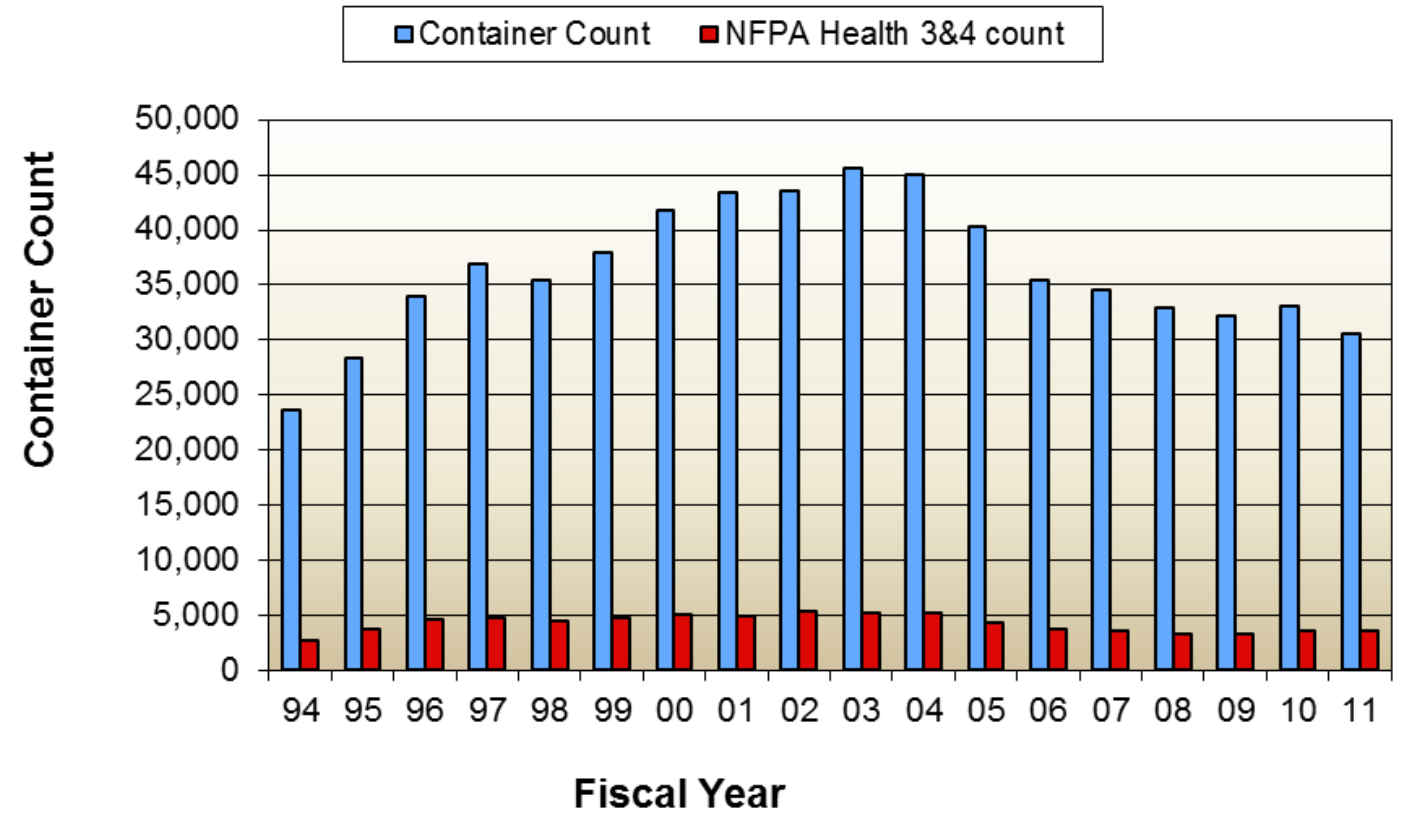

Figure 4-2 SNL/CA Hazardous Material Inventory

\section{Objective 2: Minimize consumption of resources (SSP)}

\section{Energy (SSP)}

The SNL/CA EMS Program supports the Sandia corporate target for energy reduction. The corporate target is to reduce energy intensity by thirty percent by the end of fiscal year 2015 from a fiscal year 2003 baseline. Figure 4-3 shows SNL/CA's energy use and intensity since 2003. Energy intensity is the amount of energy used per square foot of building space (presented as BTU/GSF/Yr). Between 2003 and 2011, the change in energy intensity at SNL/CA has been negligible. 


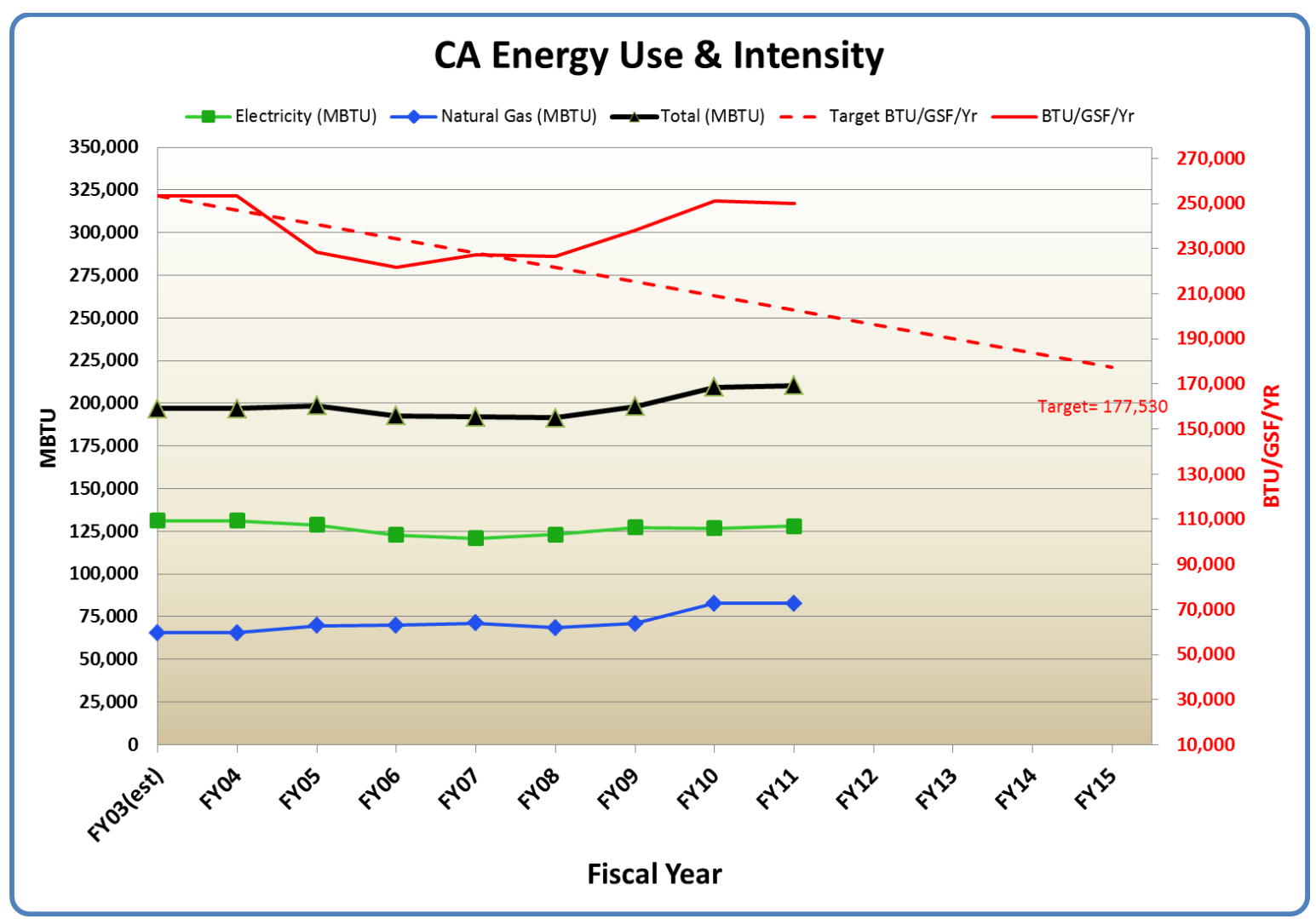

Figure 4-3 SNL/CA Energy Consumption

\section{Water (SSP)}

Figure 4-4 presents fiscal year water use data for SNL/CA since $2007^{4}$. The site target for water use is a 26 percent reduction by fiscal year 2020, using fiscal year 2007 data as a baseline. With the exception of 2010 , there has been a steady decrease in water use and intensity during the target period. The increase in 2010 was likely the result of regulatoryrequired watering of Arroyo Seco restoration areas.

${ }^{4}$ Data presented in Section 2.4.2 reflects calendar year data and differs from that presented in Figure 4-4 that reflects fiscal year data. 


\section{CA Water Use \& Intensity}

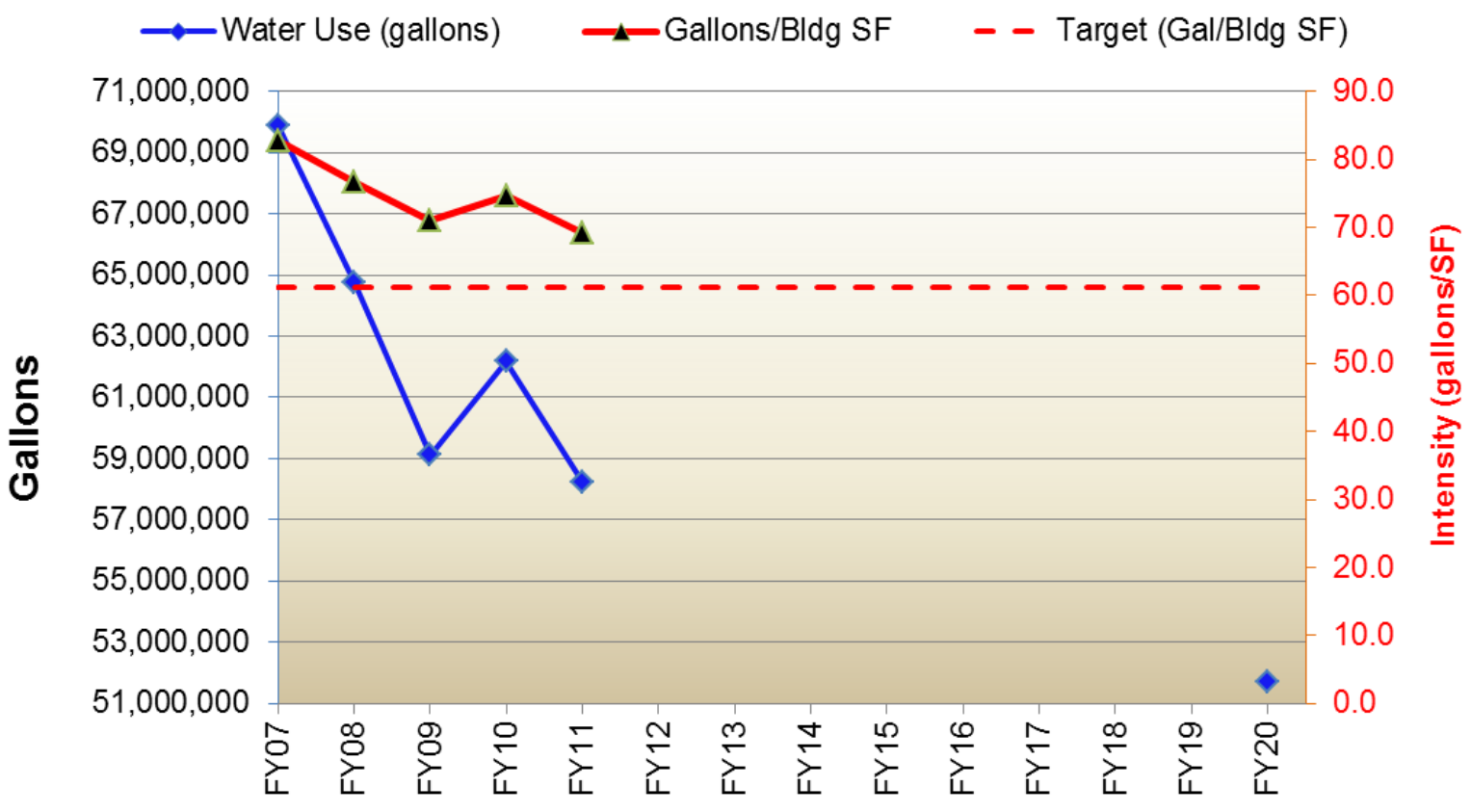

Fiscal Year

Figure 4-4 Water Consumption at SNL/CA

\section{Objective 3: Minimize the production of waste and waste water}

\section{Waste Water}

Figure 4-5 shows volume of sewer effluent discharged by SNL/CA from 2001 through 2011. Sewer discharge in 2011 was 9.2 million gallons. The large drop from the 2010 discharge (25 million gallons) is due to a new, more accurate sewer flow meter that was installed in March 2011, not to any operational change at SNL/CA. SNL/CA has a stated goal of reducing the quantity of sewer effluent, although no numeric targets have been set. Due to the change in flow meter, it is not appropriate to discuss trends at this time. 


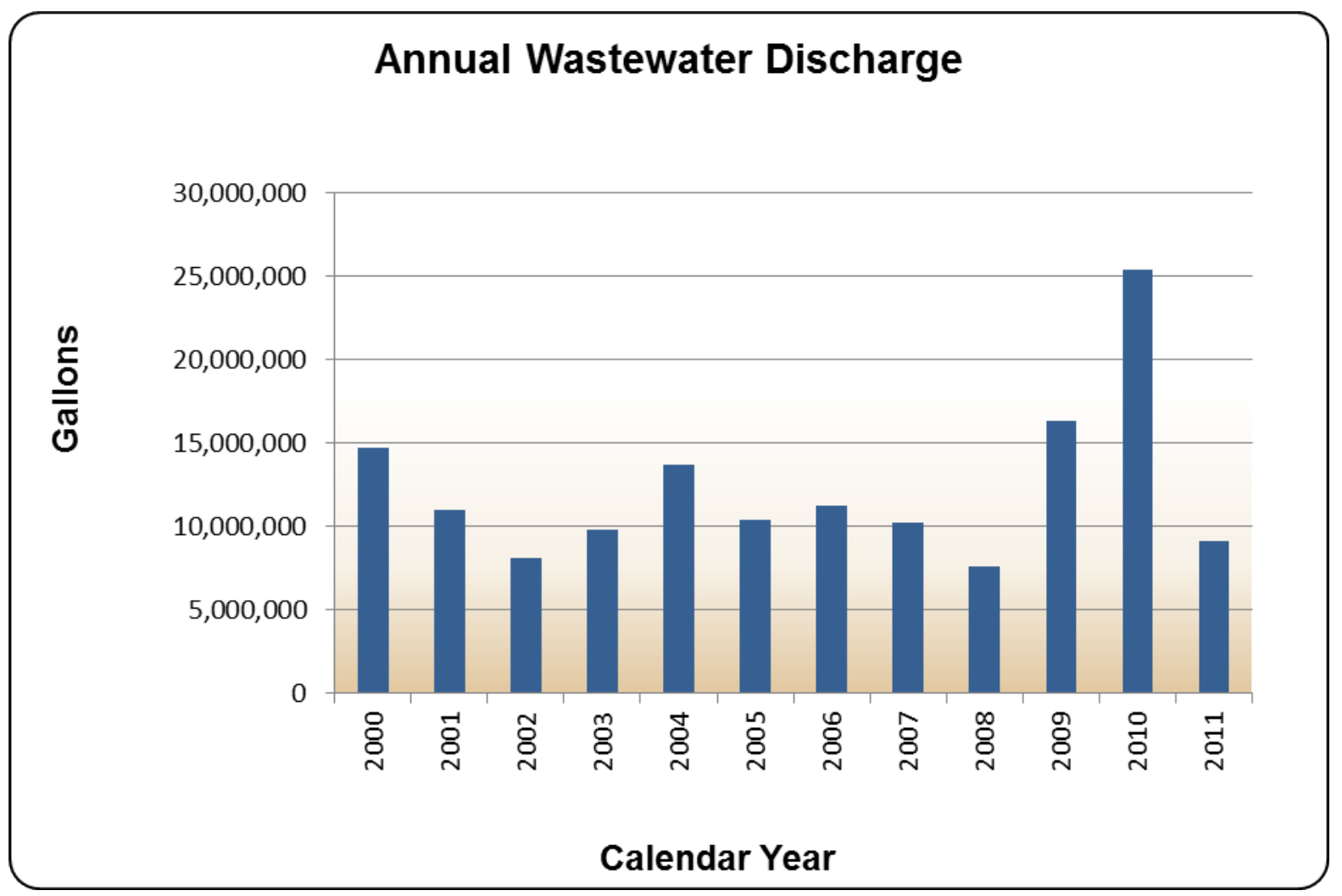

Figure 4-5 Annual Wastewater Discharges

\section{Radioactive and Hazardous Waste}

Although SNL/CA does not have a specific target for radioactive and hazardous waste reduction, we strive to minimize generation of these wastes through process controls, recycling, and reapplication of chemicals from one activity to another. Figures 4-6 and 4-7 show hazardous and radioactive waste generated since 2005, respectively. As shown, waste generation in both categories fluctuates from year to year depending on the nature and scope of research and facilities projects conducted. 


\section{Hazardous Waste Generated at SNL/CA}

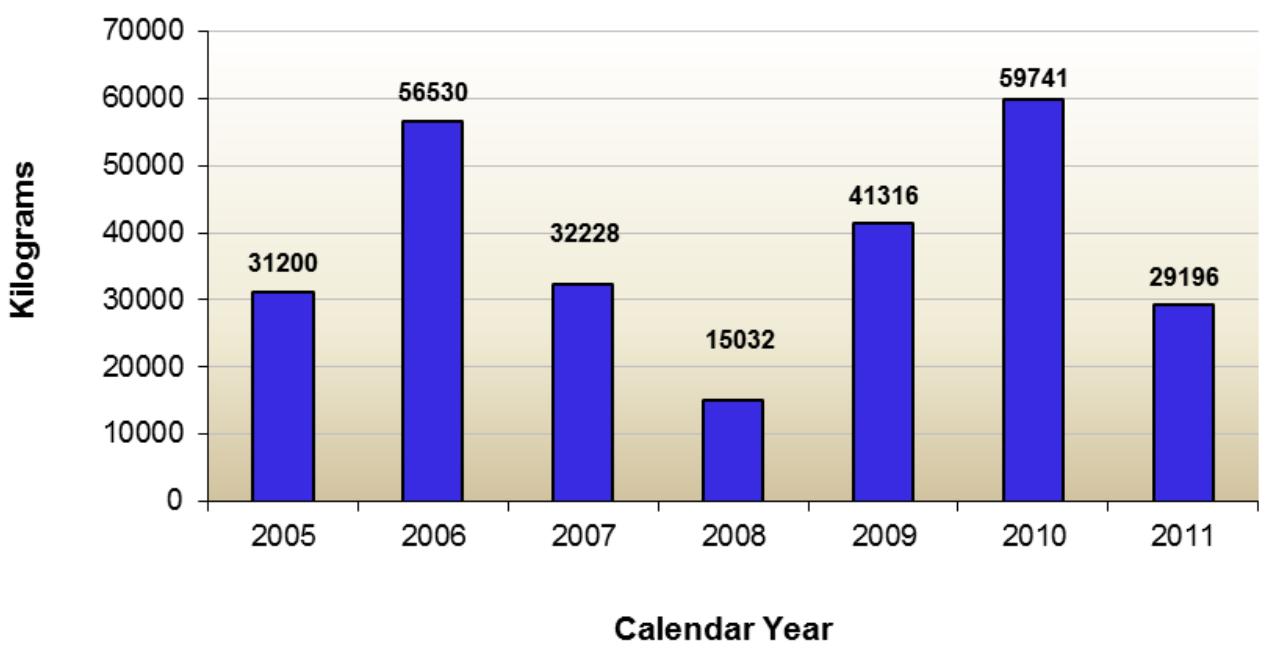

Figure 4-6 Hazardous Waste Generated at SNL/CA

Radioactive Waste Generated at SNL/CA

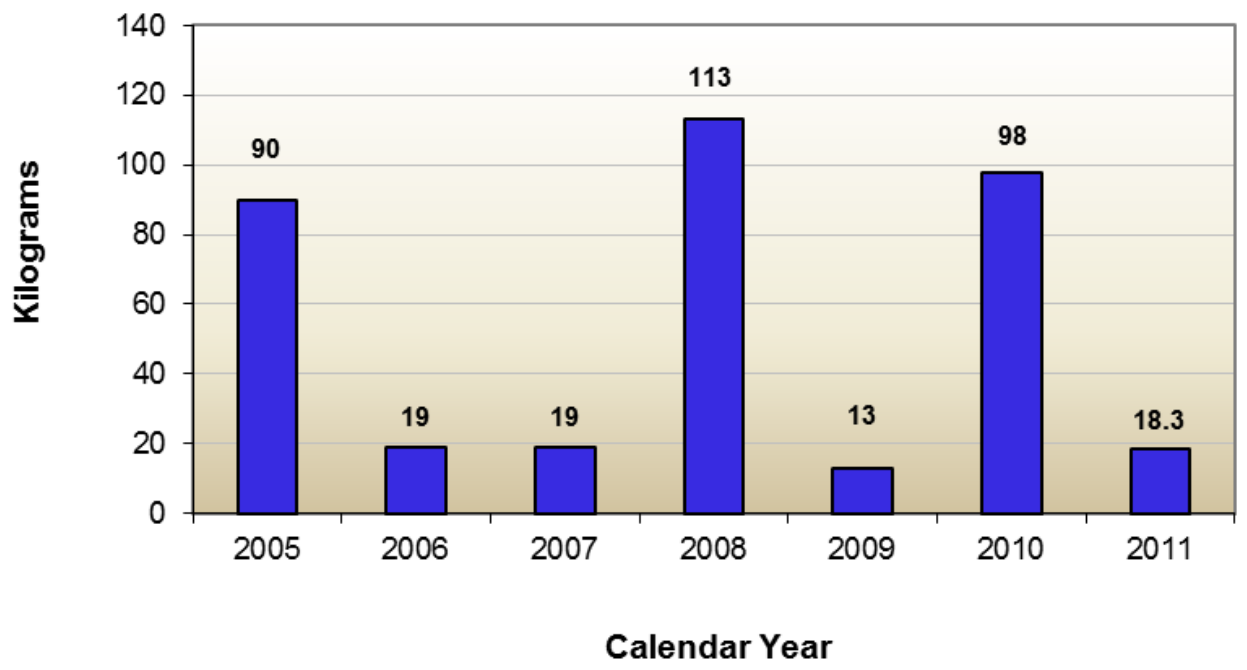

Figure 4-7 Radioactive Waste Generated at SNL/CA 


\section{Solid Waste (SSP)}

SNL/CA management established a target to divert from disposal $65 \%$ of non-hazardous solid waste by fiscal year 2012. As shown in Figure 4-8, this target was exceeded the last two years through recycling and reuse. More than $65 \%$ of construction debris was also diverted annually over the two-year period. The quantity of routine non-hazardous solid waste (excludes construction debris) sent to the landfill in 2011 increased by 18 metric tons from 2010. Although site metrics show an increase in actual quantity, the percent of solid waste diverted from landfill disposal remained about the same at 76 percent. The 2011 increase in landfill waste is attributed to a general increase in site activity (primarily maintenance and operations) that occurred during the year. Figure 4-9 presents routine landfill waste data for fiscal years 2003 to 2011 .

\section{Diversion of Solid Waste and Construction Debris}

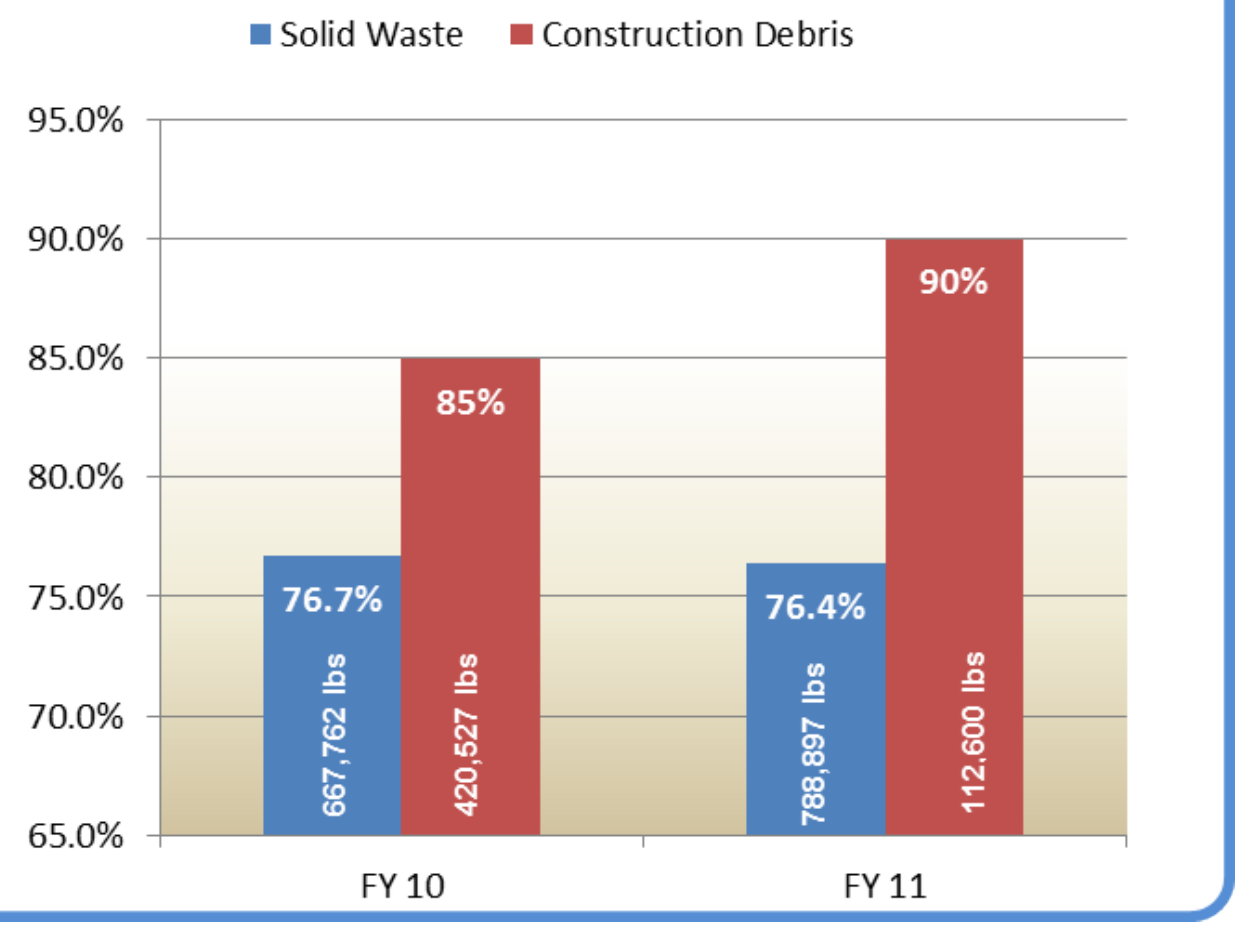

Figure 4-8 Solid Waste and Construction Debris Diverted From Landfill Disposal 


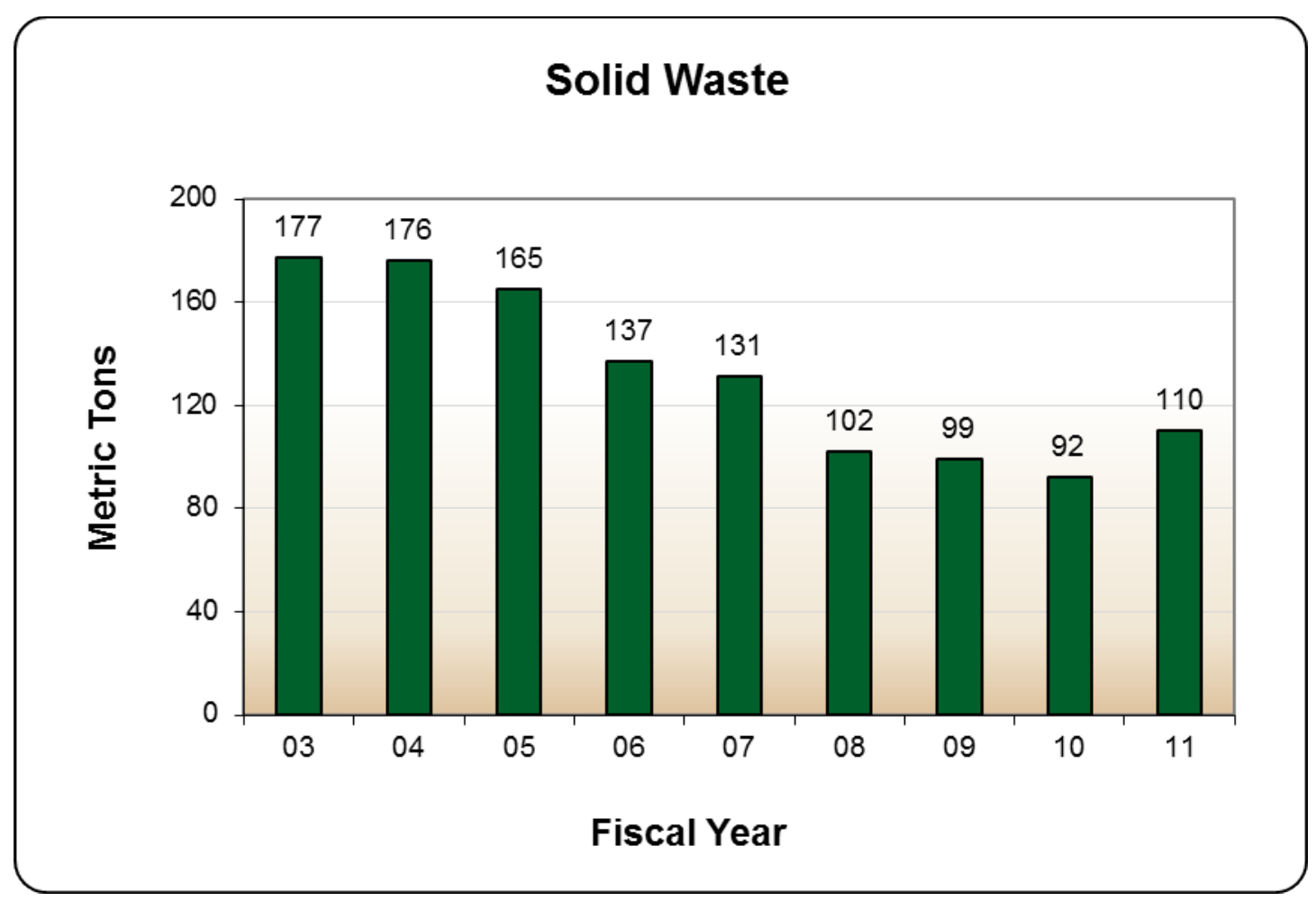

Figure 4-9 SNL/CA Landfill Waste

Objective 4: Minimize air pollutant and greenhouse gas emissions (SSP)

Targets for this objective include reducing scope 1 and 2 greenhouse gas (GHG) emissions by 28 percent and reducing scope 3 GHG emissions by 13 percent by FY 2020 from an FY 2008 baseline. Table 4-2 identifies the components of each emissions category.

Table 4-2 Green House Gas Emissions by Category

\begin{tabular}{lll}
\hline Scope 1 & Scope 2 & Scope 3 \\
\hline Natural gas consumption & Purchased electricity & Employee commuting \\
Stationary combustion & & Business ground and air travel \\
Fleet fuel consumption & & Transmission and distribution losses \\
Process gases and fugitive emissions & & Contracted (off-site) waste water treatment \\
& & Contracted (off-site) municipal waste disposal \\
\hline
\end{tabular}

SNL/CA personnel do not measure reductions in GHG emissions separately but provide input to Sandia's corporate metrics. In 2011, the following activities were completed to support the objective and targets:

$>$ replaced seven natural gas-fired boilers with cleaner, more energy efficient models;

$>$ replaced seven roofs with cool roofs;

$>$ replaced fluorescent lamps with more energy efficient models;

$>$ replaced building heating / air conditioning control systems to allow for automatic shutdown and set-back during nonstandard work hours; 
implemented automatic computer power management;

$>$ continued to divert solid waste from landfill disposal; and

$>$ installed a sulfur hexafluoride (SF6) recovery unit for laboratory equipment.

The State of California has many regulations addressing the reduction of GHG emissions. The regulations that are applicable to SNL/CA operations are:

$>$ Sulfur Hexafluoride (SF6) Emission Reductions from Gas Insulated Switchgear

$>$ SF6 Reductions from Non-Electric and Non-Semiconductor Applications (e.g. research applications)

$>$ Reduction of Emissions of Fluorinated Gases from Semi-Conductor Operations

$>$ Refrigerant Management Program: Regulation for Non-Residential Refrigeration Systems

SNL/CA tracks usage and emissions of GHGs, repairs leaks and equipment, and reports data to either the California Air Resources Board or the Bay Area Air Quality Management District as required by these regulations. Table 4-3 provides a summary of GHG reporting.

Table 4-3 Summary of GHG Reporting, 2011

\begin{tabular}{ll}
\hline Greenhouse Gas & Emissions \\
\hline SF6 Emissions from Gas Insulated Switchgear & $7 \%$ leak rate (14 lbs of SF6)* \\
\hline PFC for Semiconductor Operations & 0.000034 million megatons CO2e \\
\hline SF6 for Research Operations & 0 emissions $* *$ \\
\hline Refrigerants & Not calculated*** \\
\hline *Leak rate and lbs of SF6 emitted are calculated per CCR Title 17 Article 4 Subarticle 3.1. \\
**Experiments using SF6 were not conducted in 2011. \\
$* * *$ Emission calculations are not required until 2014 for SNL/CA.
\end{tabular}

\section{Objective 5: Preserve and, when possible, enhance the site's natural habitat}

In June 2006, an Arroyo Seco Improvement Program was initiated to address erosion and storm water control within the arroyo. The improvement program includes restoration of riparian habitat at select locations along the arroyo. Approximately 0.05 acres of riparian habitat were restored in 2006 and 2.49 acres in 2009 by planting a variety of native trees and reseeding disturbed areas with native grasses. The goal for tree survival at all areas is 85 percent. For grasses and shrubs, the goal is 75 percent cover. In 2009, repairs and/or restoration were completed at nine additional locations along the arroyo. Two areas previously planted were also replanted in 2009. Irrigation systems were installed at each restored site to support plant growth and survival. SNL/CA personnel evaluate plant survival annually. The most recent evaluation was conducted in October 2011. Willow and tree survival at many of the restored sites currently meets or exceeds the overall success criteria established in the permit (85\%). A minimal amount of replanting of willows will be needed. Grass and shrub cover was evaluated in June 2011. Although the success criteria for cover has not yet been met, sufficient progress was noted and reseeding of native grasses and shrubs is not required at this time. 


\section{Objective 6: Design and manage all buildings and facilities using "green" principles (SSP)}

Sandia's target for sustainable facility design and management is to achieve LEED (Leadership in Energy and Environmental Design) Gold certification for all new construction greater than five million in cost and to meet the Guiding Principles for Federal Leadership in High-Performance and Sustainable Buildings for projects equal to or less than five million in cost. During 2011, LEED Gold certification was achieved for the Combustion Research, Computational, and Visualization facility that was constructed in 2010.

\section{Objective 7: Maintain sewer effluent within regulatory discharge limits}

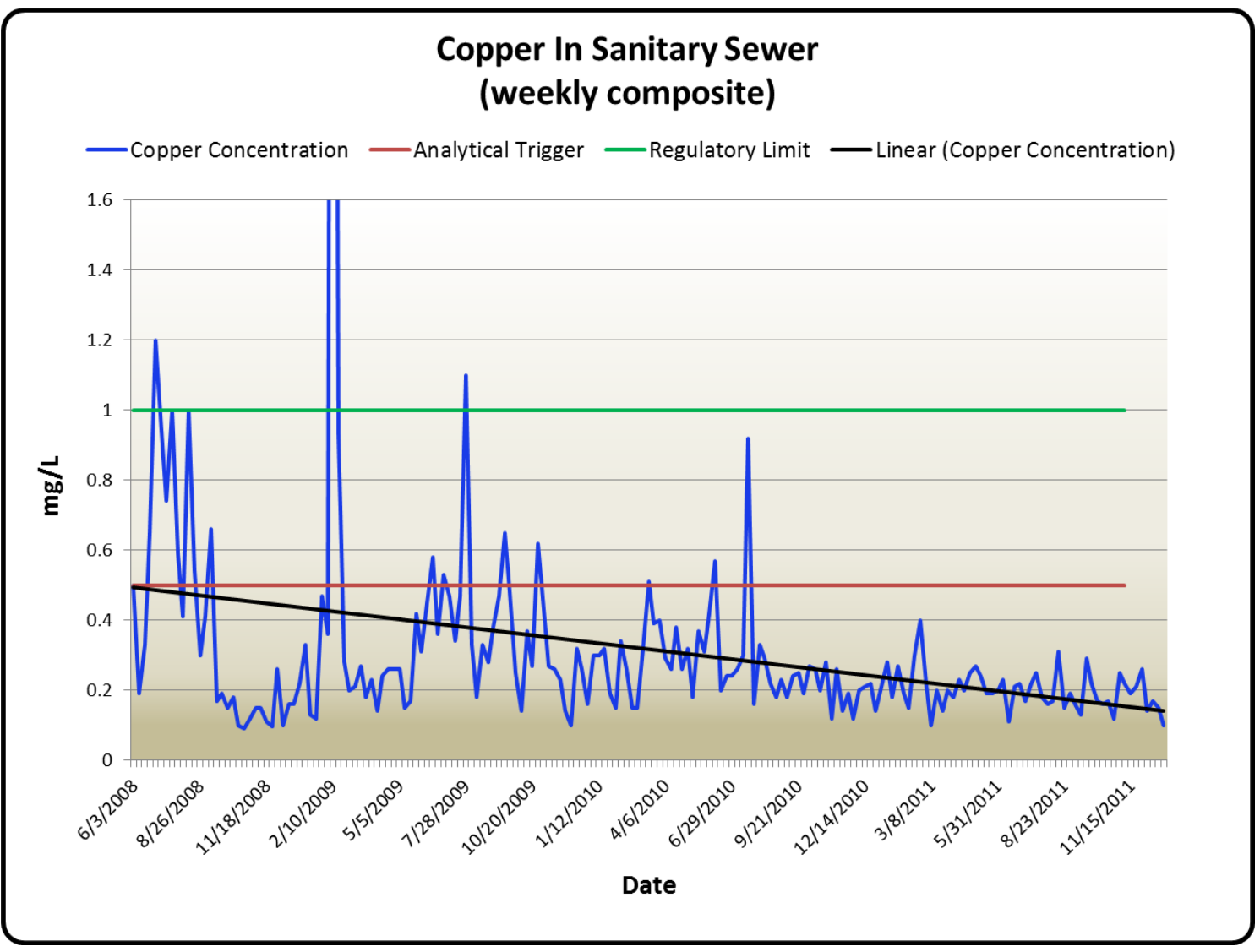

Figure 4-10 Weekly Composite Copper Concentrations in Wastewater

SNL/CA equipment continuously monitors wastewater generated on site. Figures 4-10 and 411 show the trend in weekly monitoring results since 2008 for copper and zinc, respectively. SNL/CA continues to show steady improvement in the concentrations of both metals in wastewater since the 2008 period when the site experienced numerous exceedances. Efforts that support improvement in sewer water quality are described in Chapter 5, Environmental Monitoring. Also reflected on the graphs are SNL/CA's goals of maintaining the level of copper and zinc below the regulatory analysis trigger level $(0.5 \mathrm{mg} / \mathrm{L}$ for copper and 1.5 $\mathrm{mg} / \mathrm{L}$ for zinc). 


\section{Zinc in Sanitary Sewer \\ (weekly composite)}

—Zinc Concentration —Analytical Trigger — Regulatory Limit — Linear Zinc

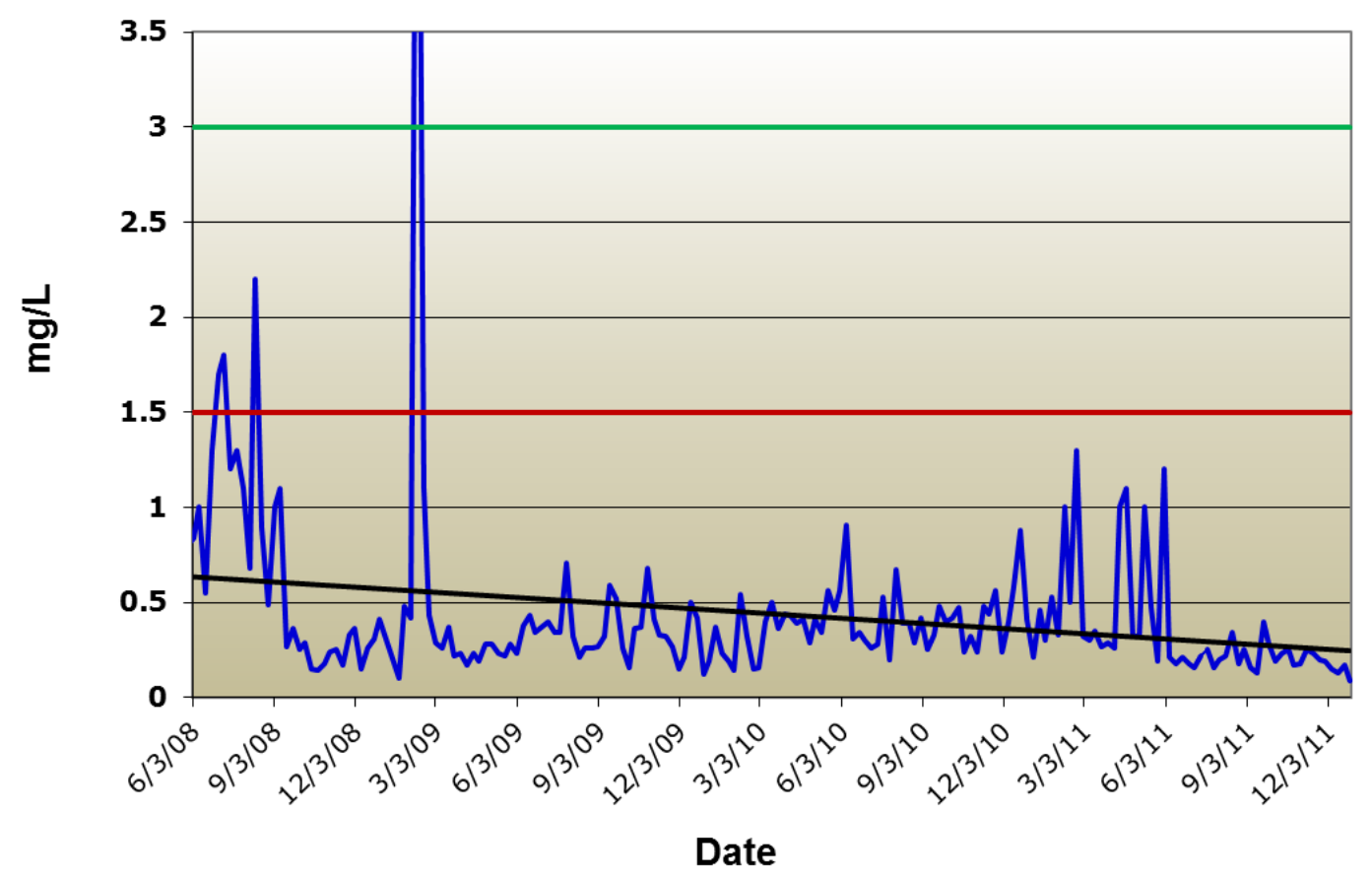

Figure 4-11 Weekly Composite Zinc Concentrations in Wastewater

\section{Objective 8: Minimize the volume and pollution of storm water runoff and water discharges}

The State of California has not yet implemented numeric limits for pollutants in storm water. However, parameters such as total suspended solids (TSS) and oil and grease (O\&G) are indicative of the quality of storm water runoff from SNL/CA parking lots and roads. Many factors can affect the quantities of TSS and O\&G in the runoff, such as the length of dry weather before sample collection, volume of runoff during the storm, etc. SNL/CA's target for storm water is to clean debris from the entire storm water drainage system at least once per year to support minimizing pollution in the runoff. The entire storm drain system was inspected and cleaned in 2011. In addition, street sweeping is implemented as another best management practice, which also minimizes storm water pollutants. In 2010, Sandia's maintenance personnel collected approximately 112 cubic yards of debris during street cleaning efforts, thus removing potential storm water pollutants. Figure 4-12 shows the highest TSS and O\&G concentrations obtained at SNL/CA storm water sampling locations during the 2010/2011 rainy season. The highest concentration of TSS in storm water during $2010 / 2011(248 \mathrm{mg} / \mathrm{L})$ was slightly lower than that obtained during the 2009/2010 rainy season $(252 \mathrm{mg} / \mathrm{L})$. The highest concentration of O\&G in 2010/2011 was $43 \mathrm{mg} / \mathrm{L}$, which is higher than observed during 2009/2010 ( $<5 \mathrm{mg} / \mathrm{L}$ at all sample locations). 


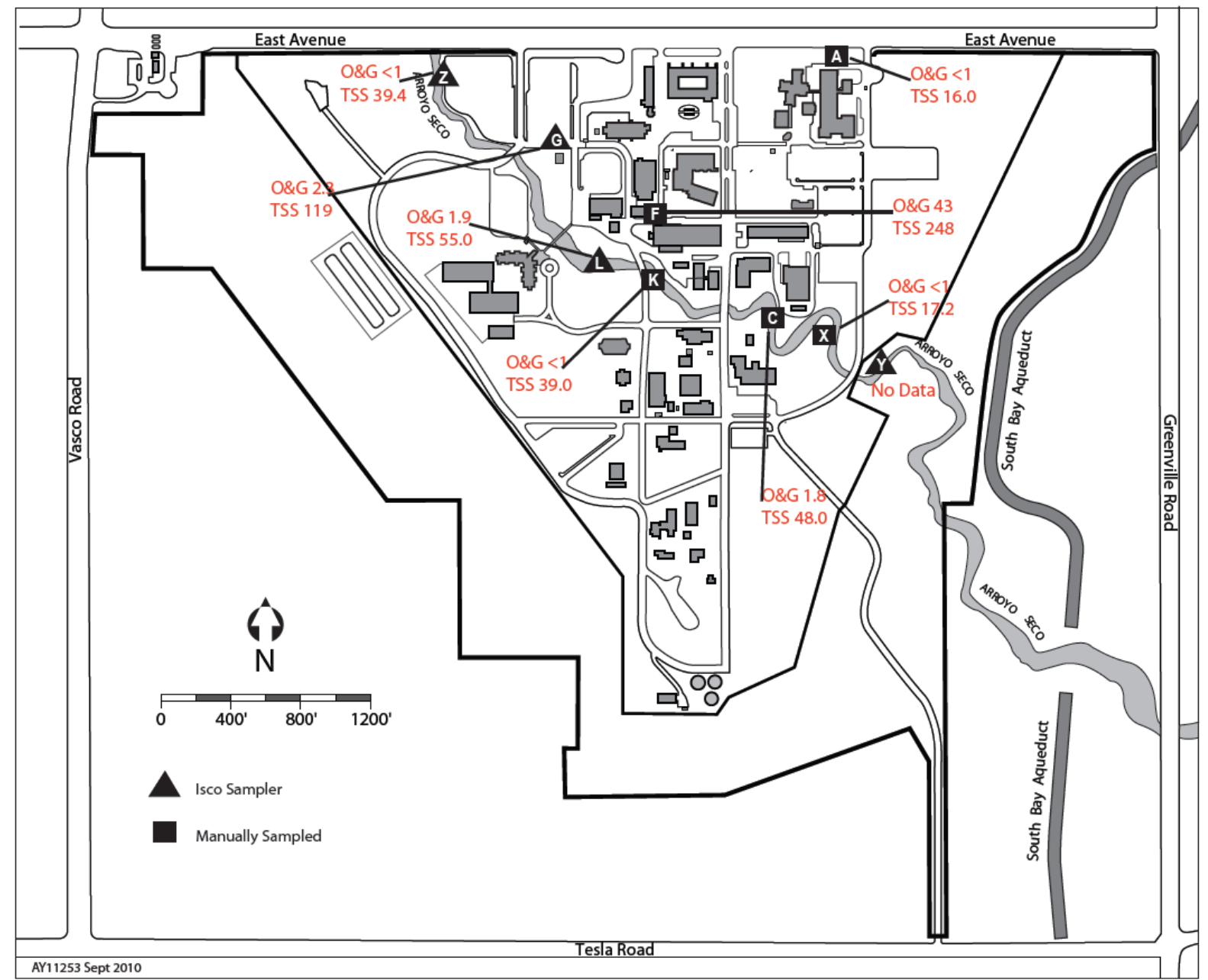

Figure 4-12 Constituents in Storm Water, 2010/2011 Rainy Season

Objective 9: Procure and use environmentally friendly products and materials (SSP)

Sandia's target for sustainable acquisition is to include a sustainable acquisition clause in 95 percent of applicable procurement contracts each year. This target also meets DOE's goals for sustainable acquisition identified in the DOE Strategic Sustainability Performance Plan (DOE 2010). During 2011, SNL/CA personnel evaluated two contract categories, construction and custodial. Although all contracts were found to include a sustainable acquisition clause, improvements to the contract language are planned in 2012. In future years, personnel will evaluate other contracting categories to ensure appropriate clauses are included.

\section{Objective 10: Minimize pollutants released to the ground or groundwater}

SNL/CA does not have any specific targets for minimizing pollutants released to the ground or groundwater. However, Sandia personnel track chemical spills that occur throughout the year. Figure 4-13 shows the number of spills and total gallons spilled each year since 1999. 
Typical materials spilled include motor oil, hydraulic oil, and coolants. Small releases to the ground surface are generally cleaned-up within a few hours by the Sandia spill response team. None of the chemical spills shown in Figure 4-13 resulted in releases to groundwater or required environmental remediation.

SNL/CA personnel are also required to report sanitary sewer overflows to the California State Water Resources Control Board. In 2011, one sanitary sewer overflow of less than 10 gallons occurred at SNL/CA. Overflows are not included in Figure 4-13.

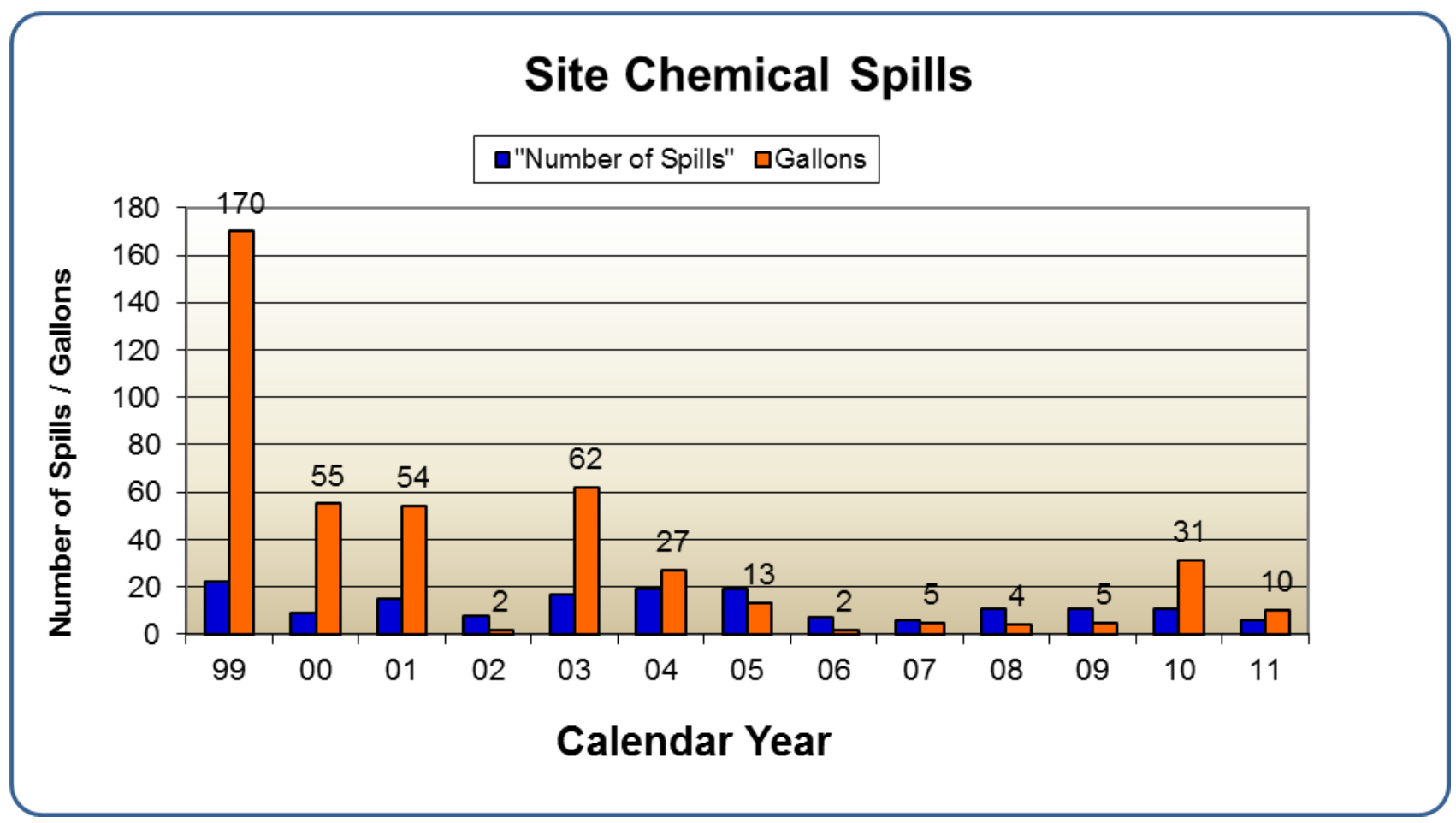

Figure 4-13 SNL/CA Chemical Spills

\subsection{Functional Environmental Program Highlights}

Six functional environmental programs support environmental management at SNL/CA, air quality, environmental monitoring, environmental planning, chemical management, pollution prevention and waste minimization, and waste management. The following sections summarize the responsibilities of each program and identify the highlights that occurred during 2011.

\subsubsection{Air Quality Program}

The Air Quality Program provides compliance assistance for all nonradiological air emission sources at SNL/CA. Program staff review all directives, laws, and regulations relevant to air emissions for applicability to the site. This program manages the air permit process, from the initial steps of preparing permit applications through implementation of permit conditions 
and annual renewals. Air Quality Program staff are responsible for evaluating proposed projects, assessing chemical use, and assessing emissions of all criteria pollutants and toxic air contaminants.

Federal, state, and local agencies continue to develop measures to reduce exposure to toxic air contaminants and criteria pollutants. In addition, the State of California is well underway in implementing many new regulations aimed at reducing emissions from diesel engines and greenhouse gases, such as sulfur hexafluoride (SF6) and other fluorinated gases. Most of the Air Quality Program's efforts and accomplishments throughout 2011 were related to these topics, and are listed below:

$>$ timely completion and submission of the BAAQMD Annual Update Package (supporting documentation and data for renewal of BAAQMD Permit To Operate);

$>$ updated the site-wide $\mathrm{SF}_{6}$ inventory;

$>$ designed SF6 Emissions From GIS database used for monitoring switchgear pressures, identifying switchgear with highest SF6 leakage, tracking SF6 cylinder inventory and computing GIS Inventory leak rate;

$>$ submitted regulatory report quantifying SNL/CA usage of SF6 in SNL/CA's accelerator and TEMs;

$>$ submitted regulatory report with usage of fluorinated gases used in SNL/CA semiconductor operations;

$>$ revised Off-Road Diesel Vehicle compliance plan to address changes in the revised regulation;

$>$ revised On-Road Diesel Vehicle compliance plan to address changes in the revised regulation;

$>$ implemented Forklift Fleet compliance plan to meet emission-limits requirements;

$>$ teamed with SNL/CA's Facilities Engineering group to install 7 new boilers that will replace existing boilers in order to meet new BAAQMD emissions limits for industrial boilers; and

$>$ prepared a permit application for a Robotic Paint Booth to be installed in 2012 and used for research applications.

\subsubsection{Chemical Management Program}

The Chemical Management Program is responsible for tracking hazardous materials (chemical and biological), managing the Material Safety Data Sheet (MSDS) library, providing MSDS information to site personnel, and for regulatory compliance reporting required under various hazardous materials regulations.

Each year, Chemical Management Program personnel conduct an annual hazardous material inventory reconciliation. In 2011, the reconciliation team achieved a $94 \%$ percent "found rate". This result meets the SNL/CA EMS performance target of greater than or equal to 94 percent. 


\subsubsection{Environmental Monitoring Program}

The Environmental Monitoring Program routinely monitors wastewater, storm water, and groundwater systems at SNL/CA to assess the effect of site operations on the public and local environment. Monitoring of external radiation at the site perimeter is also conducted under this program. Routine monitoring activities and results are presented in Chapter 5.

During 2011, Environmental Monitoring Program personnel focused on modifying the sampling system design at the sanitary sewer sampling station, and on cleaning the sewer system. The new sampling system was placed into operation in 2011. The sewer system was cleaned during the summer of 2011, and selected sewer sumps will be cleaned in early 2012 .

Environmental Monitoring Program staff also continued to investigate methods to control or eliminate metals in the sewer effluent during 2011. The current belief is that the higher than expected presence of copper and other metals in the sanitary sewer, in general, is due to biochemical processes that take place under anaerobic conditions that cause a concentration of metals from dilute, diffuse sources across the campus. During 2011, SNL/CA personnel performed inoculations of the sanitary sewer with a bacterial product designed to displace sulfate-reducing bacteria (a theorized source of the biochemical process described above). Results of this inoculation are being evaluated.

\subsubsection{Environmental Planning Program}

The Environmental Planning Program is responsible for site level National Environmental Policy Act and ecological activities and cultural and historic resource reviews. Each year, Environmental Planning Program staff compares actual site operations to the maximum operations scenario presented in a site-wide environmental assessment (SWEA) to determine whether SNL/CA operations remain within the bounding impact analysis. Table 4-3 presents a summary of the comparison and an evaluation of the results.

Table 4-4 Comparison of 2011 Operations with SWEA Envelope

\begin{tabular}{|c|c|c|c|}
\hline Activity / Unit & $\begin{array}{l}\text { SWEA Envelope (maximum } \\
\text { operations) }\end{array}$ & Calendar Year 2011 & $\begin{array}{l}\text { Site Operations Remain } \\
\text { Within Impact Analysis }\end{array}$ \\
\hline \multicolumn{4}{|l|}{ Proposed Action } \\
\hline Site mission & Supports DOE, NNSA, DHS & No change & Yes \\
\hline $\begin{array}{l}\text { Arroyo Seco } \\
\text { improvements }\end{array}$ & 20 tasks & $\begin{array}{l}14 \text { tasks completed as } \\
\text { of December } 31,2011\end{array}$ & Yes \\
\hline Increase operations & Increase to 2 shifts & 1 shift & Yes \\
\hline New facilities & $\begin{array}{l}5,000 \text { sf badge office; new } \\
16,000 \text { sf laboratory; } 84,000 \mathrm{sf} \\
\text { laboratory replacement for } \\
\text { Building } 916\end{array}$ & $\begin{array}{l}9,000 \mathrm{sf} \text { as of December } \\
31,2011 \text { (badge office } \\
\text { trailer } 500 \mathrm{sf} \text {, } \\
\text { computational facility } \\
8,500 \mathrm{sf} \text { ) }\end{array}$ & Yes \\
\hline Demolition & $100,000 \mathrm{sf}$ & $\begin{array}{l}38,376 \text { sf as of } \\
\text { December } 31,2011\end{array}$ & Yes \\
\hline \multicolumn{4}{|l|}{ Land Use } \\
\hline Construction area & 93 acres & $\begin{array}{l}8 \text { acres as of December } \\
31,2010\end{array}$ & Yes \\
\hline Wildlife reserve & 30 acres minimum & 106 acres & Yes \\
\hline \multicolumn{4}{|l|}{ Geology / Soil } \\
\hline $\begin{array}{l}\text { Solid waste } \\
\text { management units }\end{array}$ & 23 units total & 22 units & Yes \\
\hline
\end{tabular}




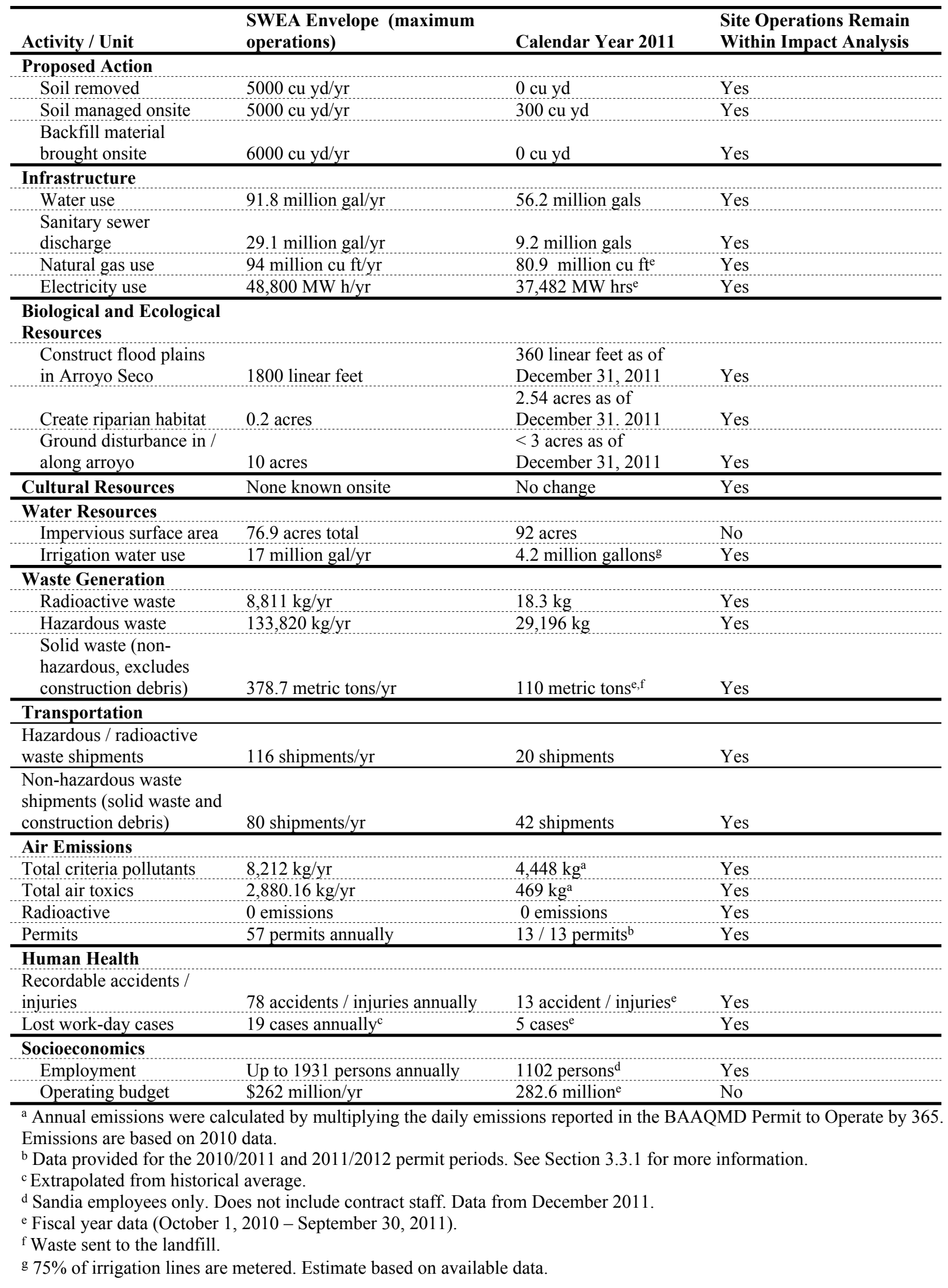




\subsubsection{Pollution Prevention and Waste Minimization Program}

The Pollution Prevention and Waste Minimization Program promotes the elimination or reduction of all waste types generated at SNL/CA. Program staff work closely with other SNL/CA organizations to establish routine and project-specific recycling programs. The program provides guidance for resource and energy conservation and assists in identifying recycled-content products for use throughout the site. See Section 4.2 for recycling and waste minimization data.

A list of activities conducted or supported by Pollution Prevention staff in 2011 is provided below.

Participated in a site-wide excess equipment campaign to characterize excess equipment for reapplication, reutilization, recycling, or disposal.

$>$ Developed guidance for including Energy Star criteria in site contracts.

$>$ Assisted in establishing a process and contract for shredding and recycling CDs and DVDs.

$>$ Implemented a pilot program for rechargeable battery stations.

$>$ Developed an interactive virtual Earth Day web page.

\subsubsection{Waste Management Program}

The Waste Management Program manages hazardous, radioactive, and mixed wastes generated by SNL/CA operations. Program personnel collect waste from the point of generation and transfer waste to onsite waste storage facilities for storage, consolidation, commingling, and packaging. The Waste Management Program establishes and maintains several contracts for offsite reclamation, recycling, treatment, and disposal of wastes. Waste Management provides regulatory oversight in accordance with federal, state, and local regulations. Program personnel manage the Resource Conservation and Recovery Act (RCRA) and Tiered permit process, and implement RCRA and Tiered permit conditions. Program staff conduct process knowledge evaluations to characterize waste types generated from specific operations. Waste Management personnel also provide waste generator training to the Sandia workforce.

In 2011, Waste Management Program personnel continued to coordinate chemical clean-out projects at the site. From June through August 2011, a substantial clean-out of old chemicals and biomaterials was completed by Waste Management staff in the Applied Biosciences Laboratory, Combustion Research Facility, and site operations areas. The cleanout was a joint effort between Waste Management staff and laboratory personnel to minimize old, unneeded chemicals and biochemicals in the site inventory.

Waste Management staff revised the internal audit process used to routinely monitor and assess site environmental regulatory compliance. Under the new process, audits focus on high regulatory risk activities and locations instead of random areas. This risk-based approach considers type of operation, specific systems and chemicals used, waste types generated, and activities with regulatory permits to determine the audit schedule and frequency. 


\section{Environmental Monitoring}

Sandia National Laboratories, California (SNL/CA) personnel monitor storm water, wastewater, groundwater, and gamma radiation. This chapter provides a summary of monitoring activities and results for each of these media. Both radiological and nonradiological data are presented.

SNL/CA personnel do not directly monitor airborne effluents. Non-radiological (chemical) emission sources do not require routine or continuous monitoring of ambient air quality concentrations. However, equipment and process usage records (e.g. hours of operation or quantity of solvents used) for emission sources are maintained. Similarly, there are no radionuclide emission sources that require routine monitoring. SNL/CA personnel maintain an inventory of radioactive isotopes (small quantity sealed and unsealed sources), and operates several radiation generating devices. Emission monitoring is not required for these materials and devices.

Typically, radiological emission data that would be obtained from radionuclide effluent monitoring is used to evaluate the potential effect that a particular site's operations may have on local populations and the environment. Because there are no radionuclide emission sources and no monitoring data for site operations, calculations for maximum individual dose or collective population dose are not possible. As an alternative to these calculations, site personnel compare gamma radiation data collected at the site perimeter to offsite data. Results of this comparison are presented in Section 5.4.

Monitoring of biota or vegetation is not required at SNL/CA. The Department of Energy (DOE) RAD-BCG Calculator, a computer tool developed by DOE, is used each year to determine the need and level of monitoring required. The results from applying the tool in 2011 are presented in Section 5.4.

\subsection{Storm Water}

All storm water runoff from SNL/CA is conveyed to the Arroyo Seco, which discharges into Alameda Creek and eventually to the San Francisco Bay. Storm water that flows off buildings, material-handling areas, parking lots, and other impervious surfaces, may pick up pollutants, such as oil and grease, soil, litter, pesticides, and fertilizers. During heavy or continuing storms, runoff may transport pollutants to Arroyo Seco before the storm water has time to evaporate or infiltrate into the ground.

To assess the impact of site operations to storm water discharges, SNL/CA personnel collect samples of surface runoff at nine locations around the site. These locations, identified on Figure 5-1, were selected because they provide the best representation of drainage areas and activities onsite. 


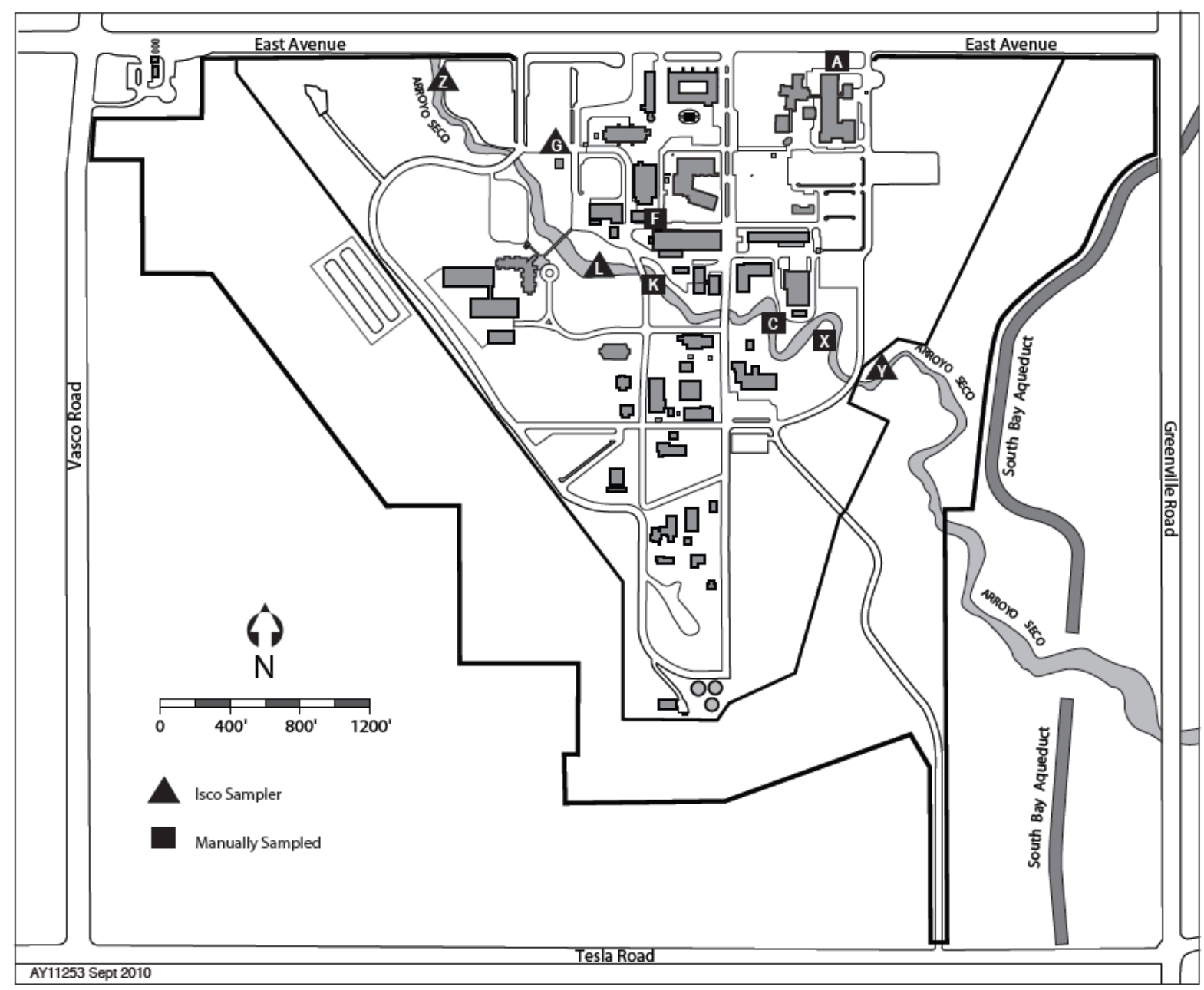

Figure 5-1 Storm Water Sampling Locations

Each of the nine locations is sampled twice each wet season, once each during two separate storm events, provided there is sufficient runoff. The wet season is from October 1 through May 31. Because any one storm may not produce enough runoff to allow for sample collection at all nine locations, sampling during more than two storm events is generally required.

Storm water discharges at SNL/CA are covered under the State of California NPDES General Permit for Storm Water Discharge Associated with Industrial Activities (General Industrial Permit) (California Water Resources Control Board 1997). The General Industrial Permit does not establish water quality standards for Analytical Parameters - Stormwater

$>$ Specific conductivity

$>\mathrm{pH}$

$>$ Total suspended solids

$>$ Oil and grease

$>$ Cyanide

$>$ Metals

$>$ Chemical oxygen demand

$>$ Nitrite + nitrate

$>$ Ammonia

$>$ Tritium storm water discharges. Consequently, a comparison of analytical results with regulatory standards cannot be made. Instead, the analytical data obtained from monitoring storm water discharge is used to optimize storm water pollution prevention activities at SNL/CA. 
Analytical results of storm water sampling for the 2010/2011 wet season are presented in Table 5-1. No pollutants were detected in storm water runoff at a level to cause concern.

Table 5-1 Summary of Analytical Results for Storm Water, 2010/2011 Wet Season

\begin{tabular}{llllll}
\hline Parameter & $\begin{array}{l}\text { Number of } \\
\text { Samples } \\
\text { Analyzed }\end{array}$ & $\begin{array}{l}\text { Number Found } \\
\text { Below } \\
\text { Detection Limit }\end{array}$ & Detection Limit & $\begin{array}{l}\text { Minimum } \\
\text { Concentration }\end{array}$ & $\begin{array}{l}\text { Maximum } \\
\text { Concentration }\end{array}$ \\
\hline Total suspended solids & 15 & 0 & $1 \mathrm{mg} / \mathrm{L}$ & $7.4 \mathrm{mg} / \mathrm{L}$ & $248 \mathrm{mg} / \mathrm{L}$ \\
\hline Specific conductivity & 15 & 0 & $10 \mu \mathrm{mho} / \mathrm{cm}$ & $28 \mu \mathrm{mho} / \mathrm{cm}$ & $75.5 \mu \mathrm{mho} / \mathrm{cm}$ \\
\hline $\mathrm{pH}$ & 15 & $\mathrm{NA}$ & None & 6.64 & 7.44 \\
\hline Oil and grease & 15 & 11 & $1 \mathrm{mg} / \mathrm{L}$ & $<1.0 \mathrm{mg} / \mathrm{L}$ & $43 \mathrm{mg} / \mathrm{L}$ \\
\hline $\begin{array}{l}\text { Chemical oxygen } \\
\text { demand }\end{array}$ & 15 & 0 & $10 \mathrm{mg} / \mathrm{L}$ & $20 \mathrm{mg} / \mathrm{L}$ & $240 \mathrm{mg} / \mathrm{L}$ \\
\hline Cyanide & 15 & 2 & $0.001 \mathrm{mg} / \mathrm{L}$ & $<0.001 \mathrm{mg} / \mathrm{L}$ & $0.0028 \mathrm{mg} / \mathrm{L}$ \\
\hline Tritium & 15 & 15 & $721-801 \mathrm{pCi} / \mathrm{L}$ & $<721 \mathrm{pCi} / \mathrm{L}$ & $<801 \mathrm{pCi} / \mathrm{L}$ \\
\hline Aluminum & 15 & 0 & $0.05 \mathrm{mg} / \mathrm{L}$ & $0.32 \mathrm{mg} / \mathrm{L}$ & $3.6 \mathrm{mg} / \mathrm{L}$ \\
\hline Arsenic & 15 & 3 & $0.0005 \mathrm{mg} / \mathrm{L}$ & $<0.0005 \mathrm{mg} / \mathrm{L}$ & $0.0013 \mathrm{mg} / \mathrm{L}$ \\
\hline Cadmium & 15 & 6 & $0.00025 \mathrm{mg} / \mathrm{L}$ & $<0.00025 \mathrm{mg} / \mathrm{L}$ & $0.0013 \mathrm{mg} / \mathrm{L}$ \\
\hline Iron & 15 & 0 & $0.05 \mathrm{mg} / \mathrm{L}$ & $0.4 \mathrm{mg} / \mathrm{L}$ & $5.4 \mathrm{mg} / \mathrm{L}$ \\
\hline Lead & 15 & 0 & $0.0005 \mathrm{mg} / \mathrm{L}$ & $0.0013 \mathrm{mg} / \mathrm{L}$ & $0.023 \mathrm{mg} / \mathrm{L}$ \\
\hline Magnesium & 15 & 0 & $0.05 \mathrm{mg} / \mathrm{L}$ & $0.56 \mathrm{mg} / \mathrm{L}$ & $2.4 \mathrm{mg} / \mathrm{L}$ \\
\hline Mercury & 15 & 4 & $0.000025 \mathrm{mg} / \mathrm{L}$ & $<0.000025 \mathrm{mg} / \mathrm{L}$ & $0.0017 \mathrm{mg} / \mathrm{L}$ \\
\hline Selenium & 15 & 15 & $0.0005 \mathrm{mg} / \mathrm{L}$ & $<0.0005 \mathrm{mg} / \mathrm{L}$ & $<0.0005 \mathrm{mg} / \mathrm{L}$ \\
\hline Silver & 15 & 15 & $0.00019 \mathrm{mg} / \mathrm{L}$ & $<0.00019 \mathrm{mg} / \mathrm{L}$ & $<0.00019 \mathrm{mg} / \mathrm{L}$ \\
\hline Zinc & 15 & 0 & $0.005 \mathrm{mg} / \mathrm{L}$ & $0.091 \mathrm{mg} / \mathrm{L}$ & $0.48 \mathrm{mg} / \mathrm{L}$ \\
\hline Ammonia-N & 15 & 0 & $0.05 \mathrm{mg} / \mathrm{L}$ & $0.09 \mathrm{mg} / \mathrm{L}$ & $0.62 \mathrm{mg} / \mathrm{L}$ \\
\hline Nitrite + nitrate & 15 & 0 & $0.1 / 0.1 \mathrm{mg} / \mathrm{L}$ & $0.15 /<0.5 \mathrm{mg} / \mathrm{L}$ & $1.1+1.6 \mathrm{mg} / \mathrm{L}$ \\
\hline
\end{tabular}

Annually, SNL/CA personnel evaluate storm water pollution prevention practices at each drainage location as part of its monitoring activities. No practices that would cause a threat to the storm water were observed.

During years of sufficient runoff, SNL/CA personnel compare the analytical results from storm water entering the site to storm water exiting the site. For the 2010/2011 storm season, a sample of storm water entering the site was not able to be collected due to insufficient runoff at sampling station Y (Figure 5-1).

\subsection{Wastewater}

Wastewater effluent generated at SNL/CA consists of sanitary and laboratory discharges. Sanitary effluent is discharged directly to the sewer system. Sewer discharges exit the site through a sewer outfall located at the northern boundary, and join with the Lawrence Livermore National Laboratory (LLNL) sewer system. Laboratory discharges are generated from general research activities, and from operations that qualify as categorical processes subject to Federal pretreatment standards. Laboratory effluent from most laboratory areas is diverted to liquid effluent control system (LECS) holding tanks prior to discharge to the sanitary sewer. SNL/CA personnel monitor wastewater at the sewer outfall, LECS tanks, and at categorical process point sources. 


\subsubsection{Sewer Outfall}

A sewer outfall and monitoring station is operated at the northern SNL/CA boundary to continuously monitor wastewater for flow and $\mathrm{pH}$. Samples are also collected at the outfall to monitor compliance with wastewater discharge limits established in the site's Wastewater Discharge Permit. The outfall sampling schedule and analytical parameters are presented in Table 5-2. Consistent with permit requirements, wastewater samples collected at the sewer outfall are not monitored for radioactive constituents.

Table 5-2 Sewer Outfall Sampling Schedule, 2011

\begin{tabular}{lll}
\hline Frequency & Sample Type & Analytical Parameter \\
\hline Daily & Composite & $\begin{array}{l}\text { Archive sample; analyzed only } \\
\text { when weekly composite sample } \\
\text { shows concentration greater than } \\
\text { or equal to 50\% of discharge } \\
\text { limit for metals. }\end{array}$ \\
\hline Weekly & & Metals \\
\hline Monthly & Composite & Total dissolved solids \\
& Composite & Total suspended solids \\
& & Biochemical oxygen demand \\
& & Chemical oxygen demand \\
\hline Monthly & Grab & Cyanide \\
\hline
\end{tabular}

${ }^{a}$ Chemical oxygen demand analyses are not required by the Wastewater Discharge Permit.

A summary of analytical results for physical parameters and metals from the SNL/CA sanitary sewer outfall is presented in Table 5-3. In 2011, all liquid effluent from the outfall complied with the site outfall discharge limits for regulated physical parameters and most metals. There were no exceedances of the discharge limit during 2011.

Sewer outfall samples are also analyzed for priority pollutants that are listed by the U.S. Environmental Protection Agency (EPA) as toxic organics. Because the list is lengthy, SNL/CA personnel report only positively identified organic constituents. In 2011, sewer outfall samples showed concentrations of Chloroform $(2.2-10 \mu \mathrm{g} / \mathrm{L})$, Bromoform $(0.62-$ $1.9 \mu \mathrm{g} / \mathrm{L})$, Toluene $(0.85-3.1 \mu \mathrm{g} / \mathrm{L}), 1,1,1$-Trichloroethane $(0.99 \mu \mathrm{g} / \mathrm{L})$, Bromodichloromethane $(0.61-0.74 \mu \mathrm{g} / \mathrm{L})$, and Dibromochloromethane $(0.55 \mu \mathrm{g} / \mathrm{L})$. All other constituents on the EPA toxic organic list were below minimum detection limits. The toxic organic discharge limit for the site is $1000 \mu \mathrm{g} / \mathrm{L}$. In 2011, SNL/CA operations did not exceed this discharge limit. Detailed sewer analyses results are provided in Section 9. 
Table 5-3 Weekly Composite Sewer Outfall Monitoring Results - Physical Parameters and Metals, 2011

\begin{tabular}{|c|c|c|c|c|c|c|}
\hline Parameter & $\begin{array}{l}\text { Number of } \\
\text { Samples } \\
\text { Analyzed }\end{array}$ & $\begin{array}{l}\text { Quantity } \\
\text { Found Below } \\
\text { Detection } \\
\text { Limit } \\
\end{array}$ & $\begin{array}{l}\text { Detection } \\
\text { Limit }\end{array}$ & $\begin{array}{l}\text { Sewer } \\
\text { Discharge } \\
\text { Limit }\end{array}$ & $\begin{array}{l}\text { Minimum } \\
\text { Concentration }\end{array}$ & $\begin{array}{l}\text { Maximum } \\
\text { Concentration }\end{array}$ \\
\hline $\begin{array}{l}\text { Total suspended } \\
\text { solids }\end{array}$ & 12 & 0 & $1 \mathrm{mg} / \mathrm{L}$ & None & $107 \mathrm{mg} / \mathrm{L}$ & $845 \mathrm{mg} / \mathrm{L}$ \\
\hline $\begin{array}{l}\text { Total dissolved } \\
\text { solids }\end{array}$ & 12 & 0 & $10 \mathrm{mg} / \mathrm{L}$ & None & $232 \mathrm{mg} / \mathrm{L}$ & $362 \mathrm{mg} / \mathrm{L}$ \\
\hline $\begin{array}{l}\text { Biochemical } \\
\text { oxygen demand }\end{array}$ & 12 & 0 & $4 \mathrm{mg} / \mathrm{L}$ & None & $100 \mathrm{mg} / \mathrm{L}$ & $430 \mathrm{mg} / \mathrm{L}$ \\
\hline $\begin{array}{l}\text { Chemical oxygen } \\
\text { demand }^{\mathrm{a}}\end{array}$ & 12 & 0 & $10 \mathrm{mg} / \mathrm{L}$ & None & $240 \mathrm{mg} / \mathrm{L}$ & $1200 \mathrm{mg} / \mathrm{L}$ \\
\hline Cyanide & 12 & 0 & $0.001 \mathrm{mg} / \mathrm{L}$ & $0.04 \mathrm{mg} / \mathrm{L}$ & $0.009 \mathrm{mg} / \mathrm{L}$ & $0.019 \mathrm{mg} / \mathrm{L}$ \\
\hline Arsenic & 52 & 5 & $0.0005 \mathrm{mg} / \mathrm{L}$ & $0.06 \mathrm{mg} / \mathrm{L}$ & $<0.0005 \mathrm{mg} / \mathrm{L}$ & $0.0027 \mathrm{mg} / \mathrm{L}$ \\
\hline Cadmium & 52 & 11 & $\begin{array}{l}0.00025 \\
\mathrm{mg} / \mathrm{L}\end{array}$ & $0.14 \mathrm{mg} / \mathrm{L}$ & $<0.00025 \mathrm{mg} / \mathrm{L}$ & $0.0015 \mathrm{mg} / \mathrm{L}$ \\
\hline Chromium & 52 & 8 & $0.0005 \mathrm{mg} / \mathrm{L}$ & $0.62 \mathrm{mg} / \mathrm{L}$ & $0.00056 \mathrm{mg} / \mathrm{L}$ & $0.0097 \mathrm{mg} / \mathrm{L}$ \\
\hline Copper & 52 & 0 & $0.0005 \mathrm{mg} / \mathrm{L}$ & $1 \mathrm{mg} / \mathrm{L}$ & $0.01 \mathrm{mg} / \mathrm{L}$ & $0.31 \mathrm{mg} / \mathrm{L}$ \\
\hline Lead & 52 & 8 & $0.0005 \mathrm{mg} / \mathrm{L}$ & $0.2 \mathrm{mg} / \mathrm{L}$ & $0.0011 \mathrm{mg} / \mathrm{L}$ & $0.0085 \mathrm{mg} / \mathrm{L}$ \\
\hline Mercury & 52 & 8 & $\begin{array}{l}0.000012 \\
\mathrm{mg} / \mathrm{L}\end{array}$ & $0.01 \mathrm{mg} / \mathrm{L}$ & $0.000031 \mathrm{mg} / \mathrm{L}$ & $0.00034 \mathrm{mg} / \mathrm{L}$ \\
\hline Nickel & 52 & 6 & $0.0005 \mathrm{mg} / \mathrm{L}$ & $0.61 \mathrm{mg} / \mathrm{L}$ & $0.0019 \mathrm{mg} / \mathrm{L}$ & $0.0069 \mathrm{mg} / \mathrm{L}$ \\
\hline Silver & 52 & 11 & $0.00019 \mathrm{mg} / \mathrm{L}$ & $0.2 \mathrm{mg} / \mathrm{L}$ & $0.0002 \mathrm{mg} / \mathrm{L}$ & $0.0026 \mathrm{mg} / \mathrm{L}$ \\
\hline Zinc & 52 & 0 & $0.005 \mathrm{mg} / \mathrm{L}$ & $3 \mathrm{mg} / \mathrm{L}$ & $0.091 \mathrm{mg} / \mathrm{L}$ & $1.3 \mathrm{mg} / \mathrm{L}$ \\
\hline
\end{tabular}

${ }^{\mathrm{a}}$ Chemical oxygen demand analyses are not required by the Wastewater Discharge Permit.

\subsubsection{Liquid Effluent Control System}

Effluent from major laboratory facilities is diverted to LECS holding tanks where wastewater can be sampled and analyzed prior to release to the sewer system. Five LECS were operated at SNL/CA during 2011. Wastewater from LECS tanks is typically analyzed for metals. Analyses for other parameters associated with the process generating the wastewater may also be done. Four of the five LECS tanks are also continuously monitored for $\mathrm{pH}$. One LECS tank that is used infrequently is monitored prior to discharge for tritium and uranium. The tank did not require discharge in 2011; consequently, analyses for radioactive constituents were not necessary.

Wastewater that does not meet the discharge limits at the sewer outfall is transferred to Waste Management for disposal. Depending on the constituents of the wastewater, it may be disposed as hazardous or non-hazardous waste. In 2011, there were no disposals of wastewater through Sandia's Waste Management Program.

\subsubsection{Categorical Processes}

Three research operations at SNL/CA are defined as federal categorical processes subject to the EPA's pretreatment standards for point sources (40 CFR Part 403, 40 CFR Part 433). 
These categorical processes include two metal finishing operations and a semiconductor manufacturing operation. Wastewater from the semiconductor manufacturing operation is sampled semiannually. The two metal finishing operations are closed-loop systems that do not discharge effluent to the sanitary sewer, and, therefore, wastewater monitoring is not required. There is an additional laboratory that may infrequently use metal cyanide complexes for electroplating, but this is done on a very small scale (less than $50 \mathrm{~mL}$ ), and all liquid waste is handled as hazardous waste. There is no discharge from this process.

Samples collected from the semiconductor manufacturing operation are analyzed for $\mathrm{pH}$, arsenic, and toxic organic pollutants. Table 5-4 presents a summary of semiannual monitoring results for the semiconductor manufacturing operation. In 2011, all wastewater from this operation met the pretreatment standards.

Table 5-4 Monitoring for Semiconductor Manufacturing Categorical Process, 2011

\begin{tabular}{|c|c|c|c|c|c|c|}
\hline Parameter & $\begin{array}{l}\text { Number } \\
\text { of } \\
\text { Samples } \\
\text { Analyzed }\end{array}$ & $\begin{array}{l}\text { Number } \\
\text { Found } \\
\text { Below } \\
\text { Detection } \\
\text { Limit } \\
\end{array}$ & $\begin{array}{l}\text { Detection } \\
\text { Limit }\end{array}$ & $\begin{array}{l}\text { Minimum } \\
\text { Concentration }\end{array}$ & $\begin{array}{l}\text { Maximum } \\
\text { Concentration }\end{array}$ & $\begin{array}{l}\text { Permit } \\
\text { Limit a }\end{array}$ \\
\hline $\mathrm{pH}$ & 2 & -- & None & 5.79 & 7.75 & $5-10$ \\
\hline Arsenic & 2 & 2 & $\begin{array}{l}0.0005 \\
\mathrm{mg} / \mathrm{L}\end{array}$ & $<0.0005 \mathrm{mg} / \mathrm{L}$ & $<0.0005 \mathrm{mg} / \mathrm{L}$ & $2.09 \mathrm{mg} / \mathrm{L}$ \\
\hline $\begin{array}{l}\text { Total toxic } \\
\text { organics }\end{array}$ & 2 & -- & Range $^{b}$ & $\begin{array}{l}\text { All below } \\
\text { detection limit }\end{array}$ & $\begin{array}{l}\text { All below } \\
\text { detection limit }\end{array}$ & $\begin{array}{l}1.37 \\
\mathrm{mg} / \mathrm{L}^{\mathrm{c}}\end{array}$ \\
\hline
\end{tabular}

\subsection{Groundwater}

SNL/CA has seven groundwater monitoring wells. Sandia personnel monitor groundwater at two former restoration areas and along Arroyo Seco. Three groundwater monitoring wells are used to monitor residual contamination at former restoration areas under a 1989 site clean-up order issued by the Regional Water Quality Control Board, San Francisco Bay Region (RWQCB). Two of these wells are located at the Fuel Oil Spill site, and one at the Navy Landfill. Four monitoring wells are located along Arroyo Seco to monitor the effect of site operations on groundwater quality. Well AS-4 is located up gradient of the developed area of the site and provides background data about local groundwater quality. Groundwater monitoring well locations are shown on Figure 5-2. MW-406, an LLNL well, is also shown on Figure 5-2. SNL/CA personnel discontinued monitoring at this location in 2005, but continues to report the results of LLNL's monitoring efforts that occur every two years. Table 5-5 provides the sampling schedule for each SNL/CA well location.

Samples have not been collected at wells FM-1 and FM-7 for several years due to lack of water. With the agreement of the Regional Water Quality Control Board, these wells were abandoned and destroyed, and replaced with two deeper wells. The new wells are located 
approximately 20 feet down-gradient of the abandoned wells. The new wells are designated FM-1R and FM-7R.

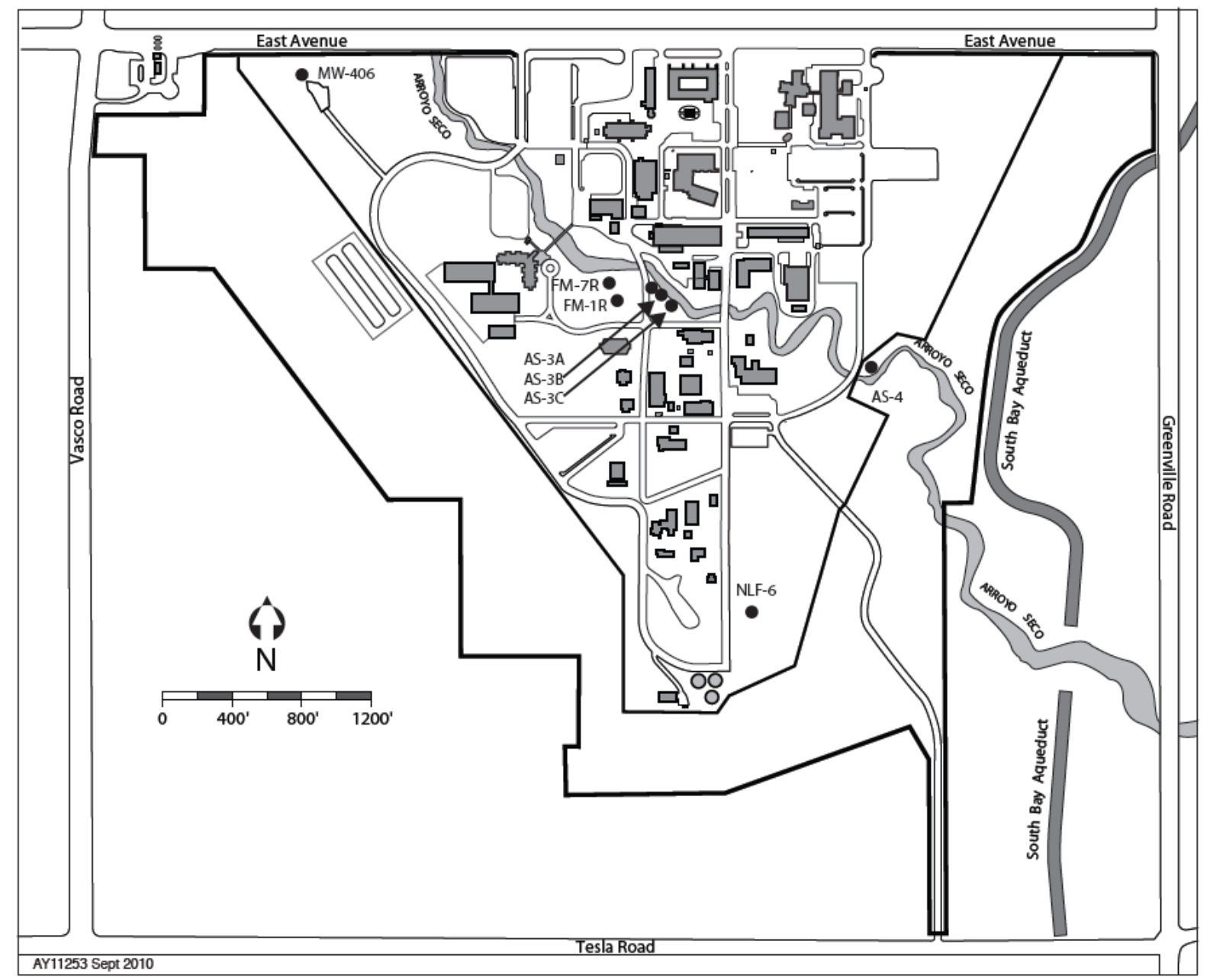

Figure 5-2 Groundwater Monitoring Well Locations 
Table 5-5 Groundwater Sampling Schedule, 2011

\begin{tabular}{lll}
\hline Well location & Sampling frequency & Analytical parameter \\
\hline $\begin{array}{l}\text { Fuel Oil Spill site } \\
\text { (Wells FM-1R, FM-7R) }\end{array}$ & Semi-annually & $\begin{array}{l}\text { Total petroleum hydrocarbons diesel- } \\
\text { methane (TPHD) (8015); water } \\
\text { elevation }\end{array}$ \\
\hline $\begin{array}{l}\text { Navy Landfill } \\
\text { (Well NLF-6) }\end{array}$ & Annually & $\begin{array}{l}\text { Volatile halogenated organics (EPA } \\
601 \text { ); water elevation }\end{array}$ \\
\hline $\begin{array}{l}\text { Arroyo Seco } \\
\text { (Wells AS-3A, AS-3B, AS-3C, and }\end{array}$ & Annually & $\begin{array}{l}\text { Metals, volatile halogenated organics } \\
\text { (EPA 601), total petroleum } \\
\text { AS-4) }\end{array}$ \\
\hline Arroyo Seco & & water elevation \\
(Wells AS-3A, AS-3B, AS-3C, and & Every two years & General minerals \\
AS-4) & & \\
\hline
\end{tabular}

Table 5-6 presents a summary of groundwater analytical results for the Navy Landfill. Groundwater analytical results for Arroyo Seco wells are summarized in Table 5-7. Fuel Oil Spill wells FM-1R and FM-7R were sampled upon well completion. The results are shown in Table 5-6. LLNL sampled MW-406 in December 2011. The only constituent of interest detected was tetrachloroethene at $2.2 \mu \mathrm{g} / \mathrm{L}$. Complete groundwater analytical results are provided in Chapter 9. As a point of reference, analytical results are compared to federal and state maximum contaminant levels (MCLs), which are applicable for drinking water sources. There are no wells at SNL/CA used as a source for drinking water and MCLs are not standards applied to groundwater at the site.

As in past years, sample results continued to show carbon tetrachloride at the Navy Landfill well (NLF-6) in 2011. The concentration was above the state MCL of $0.5 \mu \mathrm{g} / \mathrm{L}$, but below the federal MCL of $5.0 \mu \mathrm{g} / \mathrm{L}$. The result is similar to that detected in past years.

Table 5-6 Summary of Groundwater Analyses, 2011

\begin{tabular}{|c|c|c|c|c|c|}
\hline & Date & $\begin{array}{l}\text { TPH-D } \\
\mu \mathrm{g} / \mathrm{L}\end{array}$ & $\begin{array}{l}\text { Trichloromethane } \\
\text { (chloroform) } \mu \mathrm{g} / \mathrm{L}\end{array}$ & $\begin{array}{l}\text { Carbon } \\
\text { Tetrachloride } \\
\mu \mathrm{g} / \mathrm{L}\end{array}$ & $\begin{array}{l}\text { Tetrachloroethene } \\
\text { (PCE) } \mu \mathrm{g} / \mathrm{L}\end{array}$ \\
\hline Detection limit & & 50 & 0.5 & 0.5 & 0.5 \\
\hline $\begin{array}{l}\text { MCL - } \\
\text { California }\end{array}$ & & - & & 0.5 & 5 \\
\hline MCL - Federal & & - & 100 & 5 & 5 \\
\hline \multicolumn{6}{|l|}{ Fuel Oil Spill } \\
\hline FM-1R & $9 / 6 / 11$ & 210 & - & - & - \\
\hline FM-2R & $9 / 6 / 11$ & $<50$ & - & - & - \\
\hline \multicolumn{6}{|l|}{ Navy Landfill } \\
\hline NLF-6 & $6 / 29 / 11$ & - & 0.75 & 1.8 & $<0.5$ \\
\hline
\end{tabular}

${ }^{a}$ All other EPA 601 parameters were non-detectable.

$\mathrm{MCL}$ - Maximum contaminant levels. 
Table 5-7 Summary of Groundwater Analyses at Arroyo Seco Wells, 2011

\begin{tabular}{|c|c|c|c|c|c|c|c|c|c|c|c|c|c|c|c|}
\hline & $\stackrel{\mathscr{\pi}}{0}$ & $\begin{array}{l}\overrightarrow{8} \\
\mathbb{8} \\
\text { 㭊 }\end{array}$ & 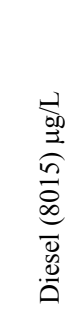 & 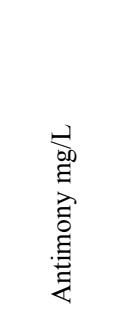 & 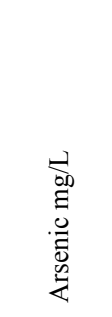 & 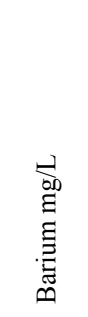 & 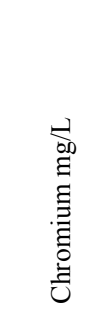 & 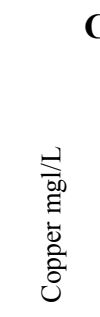 & 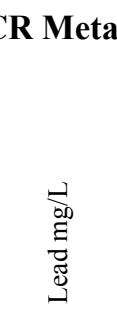 & 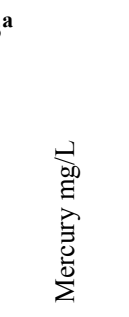 & 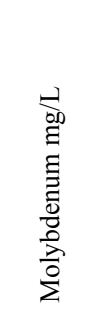 & 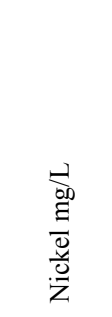 & 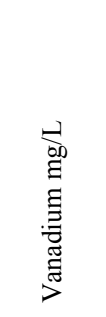 & 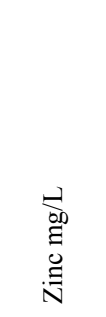 & 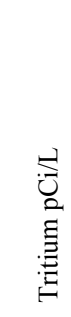 \\
\hline $\begin{array}{l}\text { Detection } \\
\text { limit }\end{array}$ & & & 50 & & 0.1 & 0.1 & 0.1 & 0.1 & 0.05 & 0.1 & 2 & 0.02 & 2 & 0.1 & 500 \\
\hline $\begin{array}{l}\text { MCL - } \\
\text { California }\end{array}$ & & & & & & 1 & 1 & & 0.05 & & & & & & \\
\hline $\begin{array}{l}\text { MCL - } \\
\text { Federal }\end{array}$ & & & & & & 2 & & & & & & & & & \\
\hline AS-3A & $6 / 29 / 11$ & - & - & 0.00057 & 0.00087 & 0.11 & 0.0085 & 0.0012 & 0.0010 & 0.00010 & 0.0029 & 0.00091 & 0.0022 & 0.0073 & $<230$ \\
\hline AS-3B & $6 / 29 / 11$ & ND & ND & $<0.0005$ & 0.00075 & 0.12 & 0.0078 & 0.0017 & $<0.0005$ & 0.000050 & 0.0032 & $<0.0005$ & 0.0022 & 0.0058 & $<230$ \\
\hline AS-3C & $6 / 29 / 11$ & ND & ND & 0.00060 & 0.0010 & 0.12 & 0.0073 & 0.0017 & 0.0011 & 0.000053 & 0.0030 & $<0.0005$ & 0.0023 & 0.0094 & $<240$ \\
\hline AS-4 & $6 / 29 / 11$ & ND & ND & $<0.0005$ & 0.0010 & 0.052 & 0.00059 & 0.0011 & $<0.0005$ & $<0.000025$ & 0.0017 & $<0.0005$ & 0.0024 & 0.0060 & $<240$ \\
\hline
\end{tabular}

${ }^{a}$ All other California Code of Regulations (CCR) parameters were non-detectable.

MCL - Maximum contaminant levels.

ND - Non-detectable. 


\subsection{Biological Dose Assessment}

SNL/CA personnel conduct a biological dose assessment each year using the graded approach presented in DOE Standard 1153-2002 A Graded Approach for Evaluating Radiation Doses to Aquatic and Terrestrial Biota (DOE 2002). The technical standard includes models for calculating doses from radionuclide concentration data obtained from sediment and water analyses. In 2011, the RAD-BCG Calculator, a computer tool developed by DOE, was used to calculate doses and determine the need for and level of monitoring required.

The first step in the graded approach is a general screening that compares concentrations of radionuclides in environmental media with derived concentration guides. The ratios of the concentrations to the concentration guides are then summed. If the total equals or exceeds one, then additional analyses are required.

The radionuclides handled in greatest quantity at SNL/CA during past or present operations are tritium and depleted uranium. Typically, tritium data from storm water sampling is used in the RAD-BCG Calculator. However, because tritium was not detected above analytical detection limits in storm water samples collected in 2011, the detection limit value was used. The sum of fractions from storm water data totaled $1.78 \times 10^{-7}$. This small fraction indicates that further analysis is not required, nor is monitoring of aquatic or terrestrial biota.

\subsection{Radiation Monitoring}

SNL/CA personnel monitor gamma radiation to ensure that site operations are not contributing significantly to the ambient radiation dose in the surrounding environment. Onsite sources that could contribute to gamma radiation include small, unsealed radioactive isotopes, sealed sources, and several radiation generating devices. Four onsite monitoring stations equipped with thermoluminescent dosimeters are maintained on site. Monitoring stations are shown on Figure 5-3. The dosimeters are collected and evaluated quarterly. The data obtained from Sandia monitoring stations is combined with that from LLNL monitoring stations located around the perimeter of the Sandia site to determine the average annual gamma radiation dose at the site perimeter. The combined dose is then compared to the average annual gamma radiation dose at more distant locations in the Livermore Valley, shown on Figure 5-4. If site operations were contributing significantly to the gamma radiation dose, the dosimeters at the site perimeter would show a higher dose than those at more distant locations.

In 2011, the average annual perimeter dose was $62.9 \mathrm{mrem}(0.629 \mathrm{mSv})$. The average annual dose measurement for distant locations was $54.4 \mathrm{mrem}(0.544 \mathrm{mSv})$. The 2011 data for both perimeter and distant locations are within the range measured over the last fifteen years. Since 1995, the average annual dose at the SNL/CA perimeter ranged from $54.3 \mathrm{mrem}$ to 68 mrem. Over this same period, the average annual dose measured at distant locations ranged from $53.4 \mathrm{mrem}$ to $73 \mathrm{mrem}$. 
The difference between the perimeter and distant location measurements for 2011 is statistically significant. Measurements at SNL/CA's thermoluminescent dosimeter stations were higher than usual during the first quarter of 2011 resulting in the statistically significant outcome. These higher than usual measurements did not continue during the remainder of the year. Although there is no explanation for this phenomenon at this time, the higher first quarter measurement was most likely the result of a sampling or measurement artifact.

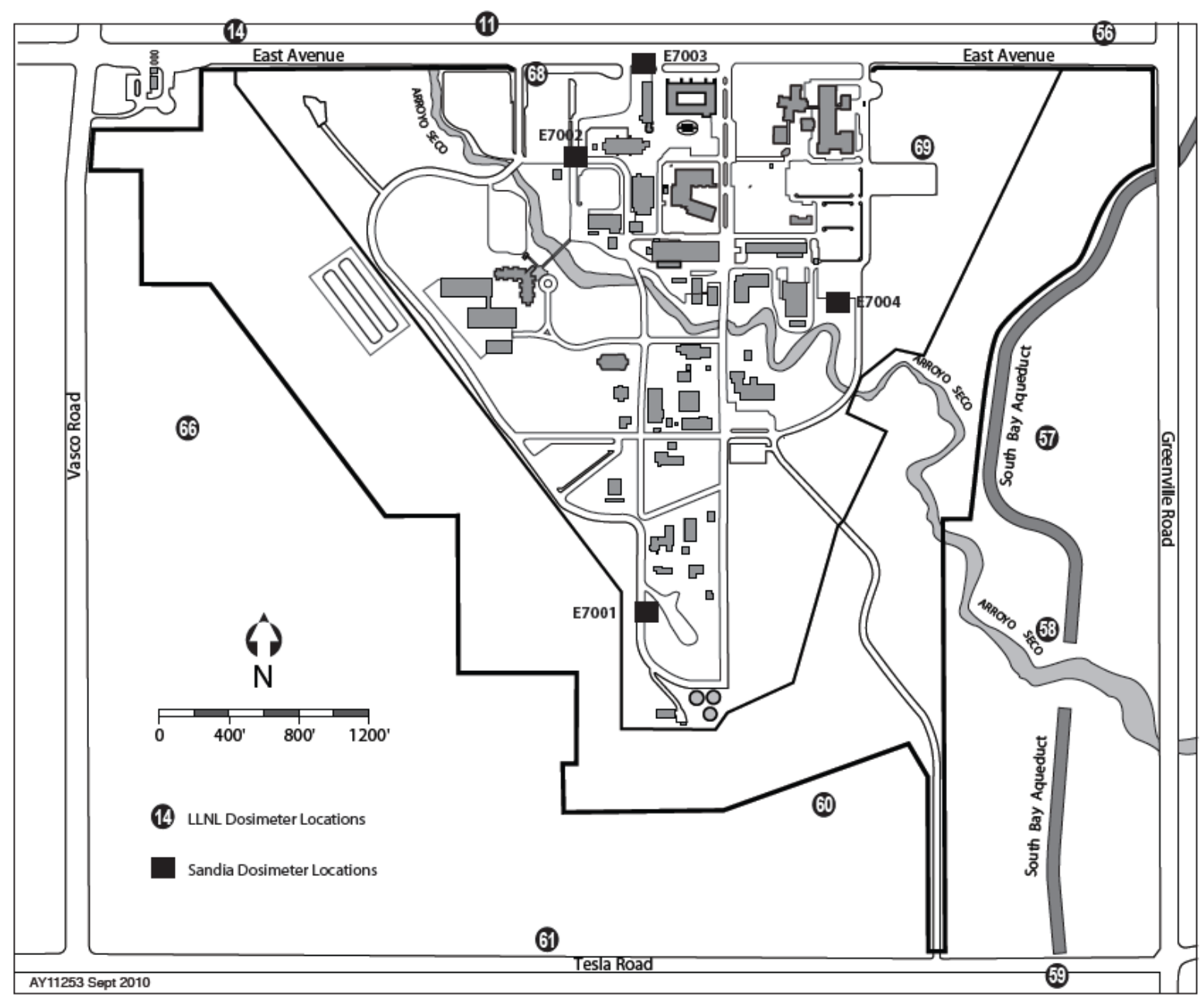

Figure 5-3 Dosimeter Locations at SNL/CA and Around Site Perimeter 


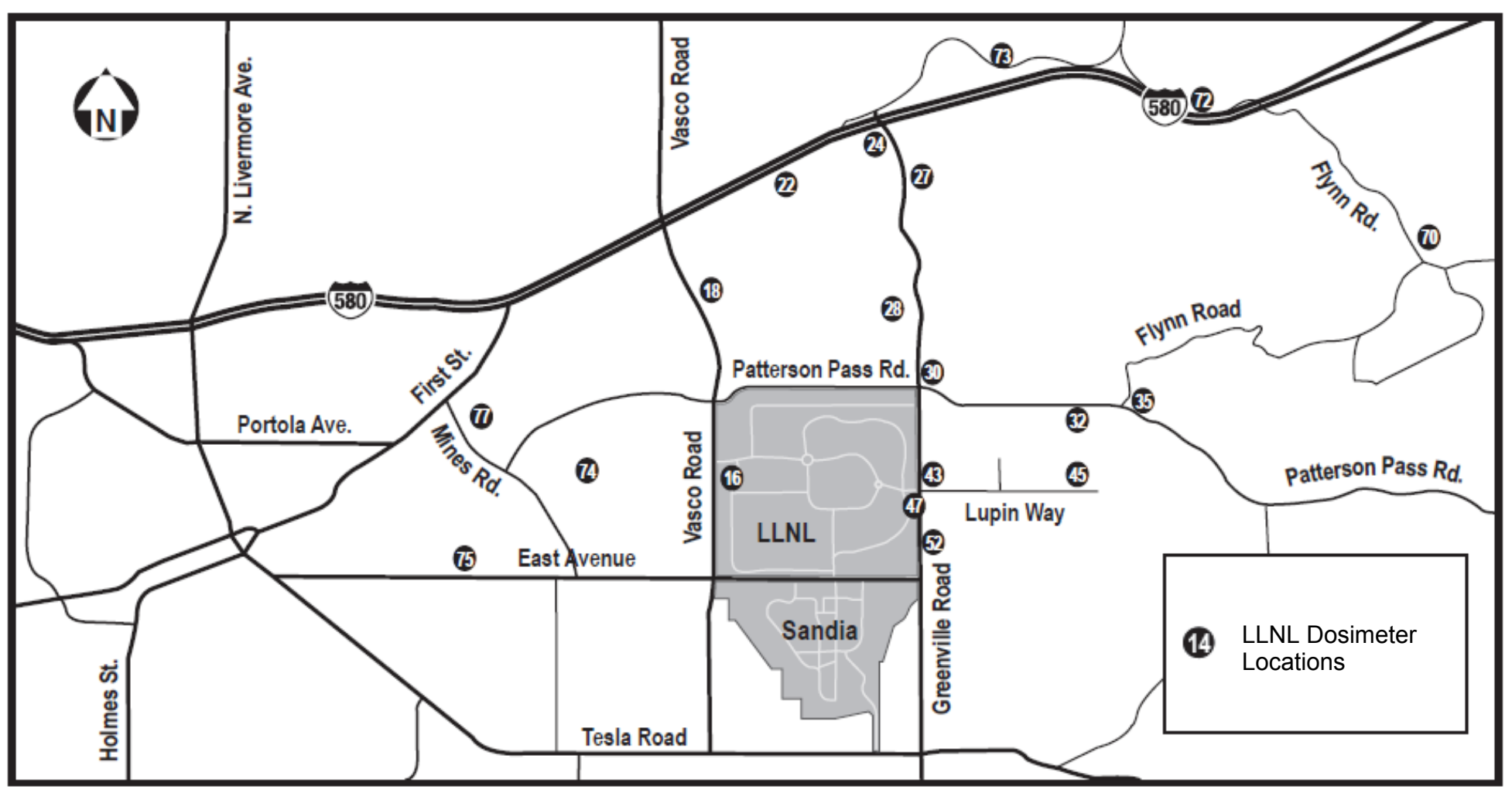

Figure 5-4 Dosimeter Locations in Livermore Valley 


\section{Quality Assurance}

Sandia National Laboratories, California (SNL/CA) follows the Sandia Corporate Process for quality assurance, CG100.5 (SNL 2011b). Compliance with the corporate quality process satisfies the requirements established in the Department of Energy (DOE) Nuclear Safety Management Regulations, Subpart A, Quality Assurance Requirements (10 CFR 830), and DOE Order 414.1D, Quality Assurance (DOE 2011a). The Environmental Management Department maintains a Quality Assurance Project Plan that describes the general quality requirements for SNL/CA environmental programs. Program-specific quality requirements are presented in annual program reports and implemented through operating procedures.

\subsection{Environmental Monitoring Quality Assurance}

DOE Order 414.1C identifies ten criteria that are integral to a quality program:

$>$ Quality assurance program

$>$ Personnel training and qualification

$>$ Quality improvement process

$>$ Documents and records

$>$ Established work processes

$>$ Established standards for design and verification

$>$ Established procurement requirements

$>$ Inspection and acceptance testing

$>$ Management assessment

$>$ Independent assessment

The Environmental Monitoring Program ensures quality in its activities through implementation of quality assurance plans and procedures. A program-specific quality assurance project plan (QAPP) addresses each of the ten criteria listed above, and documents quality assurance activities performed for the program (SNL/CA 2005). The SNL/CA Environmental Monitoring Annual Program Report provides a detailed description of the monitoring and surveillance activities conducted at SNL/CA (SNL/CA 2011a). Additional program operating procedures specify training requirements, establish work processes, define data verification and validation processes, and identify reporting and records management requirements. The operating procedures are reviewed by subject matter experts and approved by the Environmental Management Department Manager.

\subsection{Environmental Sampling}

Protocols for environmental sampling at SNL/CA are contained in activity specific operating procedures. Elements of these protocols include appropriate sampling methods and equipment; sampling frequency; sampling locations; and sample handling, storage, and packaging. Implementation of established protocols ensures that samples are representative of the environmental medium monitored and that monitoring requirements outlined in permits, DOE orders, and regulations are met. Chain-of-custody protocols are also used to ensure quality control through proper transfer of samples from the point of collection to the analytical laboratory. 


\subsection{Sample Analyses}

Analyses of samples collected at SNL/CA are performed using one of three avenues, depending on the sample medium or constituent analyzed. The three avenues are: a State accredited laboratory; the SNL/CA Health Protection Laboratory; or the Sandia National Laboratories, New Mexico (SNL/NM) Health Instrumentation Laboratory.

\subsubsection{Accredited Laboratory}

A State of California accredited laboratory performs analyses of non-radiological samples collected at SNL/CA. To receive accreditation, a laboratory must implement a quality assurance plan. These laboratories are periodically inspected by the California Environmental Protection Agency to ensure that they are operating within regulatory and quality assurance requirements. Consistent with industry standards, non-radiological samples are processed according to federal Environmental Protection Agency methods.

\subsubsection{SNL/CA Health Physics Laboratory}

Tritium analyses of storm water are performed by the SNL/CA Health Protection Department in an onsite laboratory. These samples are analyzed by liquid scintillation counting, a standard technique for tritium analysis. The Health Physics Laboratory follows the guidance in the Sandia National Laboratories (SNL) Radiation Protection Department Quality Assurance Plan (SNL 2009), and meets the Sandia and DOE quality criteria.

\subsubsection{SNL/NM Health Instrumentation Laboratory}

Thermoluminescent dosimeters used to collect gamma radiation measurements are processed by the Health Instrumentation Department at SNL/NM following established protocols and quality assurance/quality control requirements under the SNL Radiation Protection Department Quality Assurance Plan (SNL 2009). Automated equipment is used to process the samples and analyze the resulting data.

\subsection{Data Verification and Validation}

SNL/CA personnel conduct data verification and validation to ensure that environmental data is precise, accurate, representative, comparable, and complete. Verification and validation are accomplished through analyses of quality control samples and by conducting statistical analyses.

\subsubsection{Quality Control Samples}

Types of quality control samples prepared for the Environmental Monitoring Program include duplicate, spiked, and blank samples. A definition of each sample type follows.

Duplicate samples are collected at the same time and location, and follow the same method, as a routine sample. These samples are used to assess the precision of sample collection and analytical processes. 
Spiked samples resemble a routine sample, but contain a known amount of one or more of the constituents of interest. These samples are obtained from an independent laboratory that certifies the concentration of the constituents.

Blank samples resemble a routine sample matrix (e.g. deionized water is used for blank water samples), but lack the constituents of interest. These samples are used to assess background levels of constituents, and possible contamination of the samples in the laboratory or in the field.

SNL/CA's goal for number of quality control samples is 20 percent of the total sample load, where feasible. This includes quality control samples initiated at the laboratory. In 2011, SNL/CA personnel collected 12 wastewater quality control samples representing 23 percent of the sample load. Two groundwater quality control samples were collected representing 28 percent of the sample load. Four storm water quality control samples were collected during the 2010/2011 wet season, representing 27 percent of the sample load.

\subsubsection{Statistical Analyses}

Statistical analyses are used to determine completeness, precision, and accuracy of monitoring and surveillance data. Prior to performing statistical analyses, the data is normalized to ensure that valid results are obtained. Descriptions of the statistical tests follow.

Completeness is evaluated by determining the ratio between the number of samples collected and the number of samples scheduled for collection. The data quality objective for completeness is 85 percent.

Precision is evaluated using three methods: determining the ratio between routine and duplicate samples; tests of significant difference; and calculating the 95 percent confidence interval. Data quality objectives vary for precision depending on the results of laboratory analyses.

Accuracy is also evaluated using three methods: determining the ratio between sample results and known values of spiked samples; tests of significant difference; and calculating the 95 percent confidence interval. Data quality objectives vary for accuracy depending on the results of laboratory analyses.

Table 6.1 summarizes the results of statistical analyses conducted in 2011. As shown, some data quality objectives failed during the year. The failed accuracy tests were mercury and BOD samples. Sandia staff worked with laboratory management to determine and resolve the issues with the mercury and BOD results. All issues have been resolved. The failed precision tests were typically parameters that can be very easily affected by the heterogeneous nature of the samples, such as suspended solids and COD. This is believed to be the source of the discrepancy. 
Table 6-1 Summary of Statistical Analyses, 2011

\begin{tabular}{|c|c|c|c|c|c|}
\hline \multirow[t]{2}{*}{ Sample Medium } & \multirow{2}{*}{$\begin{array}{l}\text { Completeness Test } \\
\text { Results }\end{array}$} & \multicolumn{2}{|c|}{ Precision Test } & \multicolumn{2}{|c|}{ Accuracy Test } \\
\hline & & $\#$ of Tests & Results & \# of Tests & Results \\
\hline $\begin{array}{l}\text { Wastewater (sanitary } \\
\text { sewer) }\end{array}$ & $100 \%$ & 6 & 4 passed & 14 & 12 passed \\
\hline Storm water & $83 \%{ }^{a}$ & 11 & 7 passed & - & - passed \\
\hline Groundwater & $78 \% \mathrm{~b}^{\mathrm{b}}$ & 1 & 1 passed & - & - passed \\
\hline
\end{tabular}




\section{References}

22 California Code of Regulations (CCR), Division 4.5, Environmental Health Standard for Management of Hazardous Waste.

10 Code of Federal Regulations (CFR) Part 830, Department of Energy, Nuclear Safety Management, Subpart A, Quality Assurance Requirements, Federal Register Vol. 66, Number 7.

10 CFR Part 1021, Department of Energy, National Environmental Policy Act Implementing Procedures.

40 CFR Part 61, Environmental Protection Agency, National Emissions Standards for Hazardous Air Pollutants, Subpart H - National Emissions Standards for Emissions of Radionuclides Other Than Radon From Department of Energy Facilities.

40 CFR Part 70, Environmental Protection Agency, State Operating Permit Programs.

40 CFR Part 82, Environmental Protection Agency, Protection of Stratospheric Ozone.

40 CFR Part 262.41, Environmental Protection Agency, Standards Applicable to Generators of Hazardous Waste, Subpart D, Record-keeping and Reporting.

40 CFR Part 403, Environmental Protection Agency, General Pretreatment Regulations for Existing and New Sources of Pollution.

40 CFR Part 433, Environmental Protection Agency, Metal Finishing Point Source Category.

7 United States Code (USC) §136, Federal Insecticide, Fungicide, and Rodenticide Act, 1972.

15 USC §2601 et. seq., Toxic Substances Control Act of 1976.

16 USC $\S 470$, National Historic Preservation Act of 1966.

16 USC $\S 703$ et. seq., Migratory Bird Treaty Act of 1918.

16 USC $§ 1531$ et. seq., Endangered Species Act of 1973.

33 USC §1251, Clean Water Act of 1977.

42 USC $\S 2011$ et. seq., Atomic Energy Act of 1954.

42 USC $\S 4321$ et. seq., National Environmental Policy Act of 1970.

42 USC $\S 6901$ et. seq., Resource Conservation and Recovery Act of 1976. 
42 USC § 6961, Federal Facility Compliance Act of 1992.

42 USC § 7401, Clean Air Act Amendments of 1990.

42 USC $\S 9601$, Comprehensive Environmental Response, Compensation, and Liability Act of 1980.

42 USC §11001 et. seq., Superfund Amendments and Reauthorization Act of 1986, Emergency Planning and Community Right-to-Know Act.

42 USC §13101 et. seq., Pollution Prevention Act of 1990.

Assembly Bill 2185, California Hazardous Materials Release Response Plans and Inventory Law, 1987.

California Health and Safety Code, Division 20, Chapter 6.5, § 25100 et. seq., Hazardous Waste Control Law.

California Health and Safety Code, Division 20, Chapter 6.7, §§ 25280-25299.8, Underground Storage of Hazardous Substances.

California Health and Safety Code, Division 20, Chapter 6.95, § 25500, et. Seq., Hazardous Materials Release Response Plans and Inventory.

California Health and Safety Code, Division 104, Part 14, §§ 117600-118360, Medical Waste Management Act.

California Regional Water Quality Control Board, San Francisco Bay Region (California RWQCB) 1989, Order No. 89-184, Revision of Site Cleanup Order, Sandia Corporation and U.S. Department of Energy, Livermore, December 1989.

California Water Resources Control Board 1997, State of California, NPDES General Permit for Storm Water Discharge Associated with Industrial Activities, April 1997.

Department of Energy (DOE) 1986, Comprehensive Environmental Assessment and Response Program, Phase I: Installation Assessment, Sandia National Laboratories, Livermore, September, 1986.

DOE 2001, DOE Order 435.1, change 1, Radioactive Waste Management, August 28, 2001.

DOE 2002, DOE Standard 1153-2002, A Graded Approach for Evaluating Radiation Doses to Aquatic and Terrestrial Biota, July 2002.

DOE 2003a, Final Site-wide Environmental Assessment of the Sandia National Laboratories/California, DOE/EA-1422, January 2003.

DOE 2003b, Site Wide Environmental Assessment for SNL/CA, Finding of No Significant Impact, March 20, 2003. 
DOE 2010, Strategic Sustainability Performance Plan, September 2010.

DOE 2011a, DOE Order 414.1D, Quality Assurance, April 25, 2011.

DOE 2011b, DOE Order 436.1, Departmental Sustainability, May 2, 2011.

DOE 2011c, DOE Order 458.1, Radiation Protection of the Public and the Environment, June 6, 2011.

DOE 2011d, DOE Order 231.1B, Environment, Safety, and Health Reporting, June 27, 2011.

Executive Order (EO) 11988, Floodplain Management, Federal Register, Vol. 42, pp. 26951, May 25, 1977.

EO 11990, Protection of Wetlands, Federal Register, Vol. 42, pp. 26961, May 25, 1977.

EO 13423, Strengthening Federal Environmental, Energy, and Transportation Management, January 24, 2007.

EO 13514, Federal Leadership in Environmental, Energy, and Economic Performance, October 5, 2009.

International Organization for Standardization (ISO) 14001, Environmental Management Systems - Requirements with guidance for use, Second edition, November 15, 2004.

Lawrence Livermore National Laboratory (LLNL) 2012, Simple Weather Report Tool, http://www-metdat.Ilnl.gov/cgi-pub/reports/simple_report.pl, January 3, 2012.

Matthews, Graham \& Associates (Matthews) 2002, Management Plan for Arroyo Seco at Sandia National Labs, Livermore, CA, April 2002.

Sandia National Laboratories (SNL) 2002, Historic Building Survey, Sandia National Laboratories/California, October 30, 2002.

SNL 2009, Radiation Protection Department Quality Assurance Plan, RPA-01-01, Issue 3, September 10, 2009.

SNL 2011a, Corporate Process: ESH100.2 Analyze and Control Hazards, January 4, 2011.

SNL 2011b, Corporate Process: CG100.5 Ensure Quality, December 16, 2011.

SNL California (SNL/CA) 2002, Sandia National Laboratories, California Environmental Information Document, SAND 2002-8053, March 2002.

SNL/CA 2005, Quality Assurance Project Plan for Environmental Monitoring Program, SAND 2005-6051, September 20, 2005.

SNL/CA 2009, Standard Operating Procedure SP471911, Handling and Storage of Pesticides, June 23, 2009. 
SNL/CA 2010, Operating Procedure 471741, Storm Drain Spill Prevention and Control, Issue F, September 17, 2010.

SNL/CA 2011a, Sandia National Laboratories, California Environmental Monitoring Program Annual Report, SAND 2011-2171, March, 2011.

SNL/CA 2011b, 2011 Annual Pollution Prevention Tracking Report, December 1, 2011.

Senate Bill 14, California Hazardous Waste Source Reduction and Management Review Act of 1989 .

United States District Court for the District of Columbia (US District Court) 2002, Case Number 01-1291 (RJL), Home Builders Associations of Northern California, et al., Plaintiffs, and El Dorado County, California, Intervenor-Plaintiff, v. Gale A. Norton, Secretary of the Department of Interior, et. al., Defendants, and Jumping Frog Research Institute, et al., Intervenor-Defendants, November 6, 2002.

US District Court, Northern District of California 2006, Case Number 02-1580-JSW (JL), Stipulated Injunction and Order, Center for Biological Diversity, Plaintiff, v. Stephen L. Johnson, Administrator, Environmental Protection Agency, and Wayne Nastri, Region 9 Administrator, Environmental Protection Agency, Defendants, and Croplife America, American Forest \& Paper Association, Western Plant Health Association, Oregonians for Food and Shelter, and Syngenta Crop Protection, Inc., DefendantsIntervenors, October 17, 2006.

United States Fish and Wildlife Service (USFWS) 2004, Proposed Rule, Endangered and Threatened Wildlife and Plants; Proposed Designation of Critical habitat for the California Red-legged Frog (Rana aurora draytonii), Federal Register, April 13, 2004 (Volume 69, Number 71).

USFWS 2005, Proposed Rule, Endangered and Threatened Wildlife and Plants: Revised Proposed Designation of Critical Habitat for the California Red-Legged Frog (Rana aurora draytonii), Federal Register, November 3, 2005 (Volume 70, Number 212).

USFWS 2006, Final Rule, Endangered and Threatened Wildlife and Plants; Designation of Critical Habitat for the California Red-Legged Frog, and Special Rule Exemption Associated with Final Listing for Existing Routine Ranching Activities, Federal Register, April 13, 2006 (Volume 71, Number 71). 


\section{Glossary}

Ambient air

Biochemical

oxygen demand

Categorical process

Chemical oxygen

demand

Dose

Dosimeter

Effluent

Emission

Ephemeral stream

External radiation

Fluvial sediments

Lacustrine

sediments

Mixed waste

$\mathrm{pH}$

Riparian
The surrounding atmosphere, usually the outside air, as it exists around people, plants, and structures. It does not include the air next to emission sources.

A measure of the amount of dissolved oxygen that microorganisms need to break down organic matter in water. Used as an indicator of water quality.

An industrial process that discharges wastewater and is regulated under 40 CFR, Part 403.

The amount of oxygen required to degrade the organic compounds of wastewater. Used to measure the overall level of organic contamination in wastewater.

A term denoting the quantity of radiation energy absorbed.

A portable detection device for measuring the total accumulated exposure to ionizing radiation.

A liquid or gaseous waste discharged to the environment.

A gaseous or liquid stream containing one or more contaminants.

A stream that flows only for a short duration during and following rainfall.

Radiation originating from a source outside the body.

A sedimentary deposit consisting of material transported by, suspended in, or laid down by a river or stream.

Sediments formed in, or relating to, a lake.

Waste that contains both radioactive and hazardous constituents.

A measure of hydrogen ion concentration in an aqueous solution. Acidic solutions have a $\mathrm{pH}$ less than 7 , basic solutions have a $\mathrm{pH}$ greater than 7, and neutral solutions have a $\mathrm{pH}$ of 7.

Pertaining to, situated in, or adapted to living on the banks of rivers and streams. 
Specific Measure of the ability of a material to conduct electricity.

conductivity

Strike-slip fault A fault with horizontal movement along the break where slipping is parallel with the strike of the fault.

Thermoluminescent A type of dosimeter. After being exposed to radiation, the material in dosimeter the dosimeter (lithium fluoride) luminesces upon being heated. The amount of light the material emits is proportional to the amount of radiation (dose) to which it was exposed.

Total dissolved Solids in water that pass through a filter. A measure of the amount of solids material dissolved in water.

Total suspended solids Solids in water that can be trapped in a filter. Solids can include silt, decaying plant and animal matter, industrial wastes, and sewage.

Transverse fault

A fault that strikes obliquely or perpendicular to the general structural trend of the region. 


\section{Groundwater Analytical Results, Well Completion Data, and Sanitary Sewer Analytical Results}


Table 9-1 Results of Groundwater Analyses at SNL/CA, 2011

\begin{tabular}{|c|c|c|c|c|c|c|c|c|c|c|c|c|c|c|c|c|}
\hline & Date & 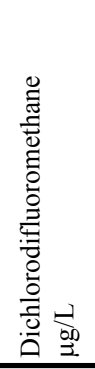 & 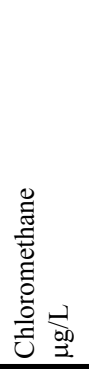 & 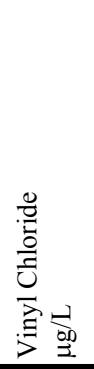 & 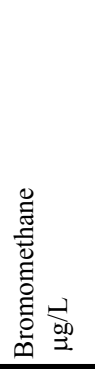 & 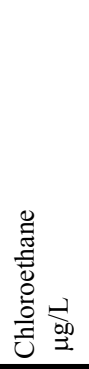 & 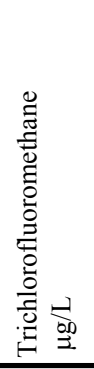 & 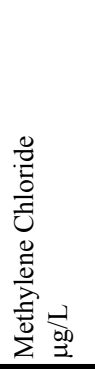 & 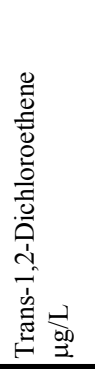 & 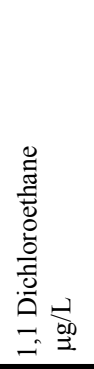 & 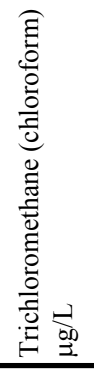 & 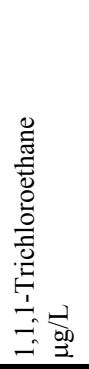 & 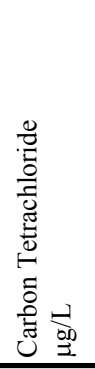 & 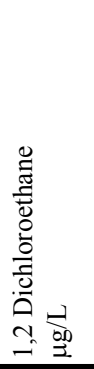 & 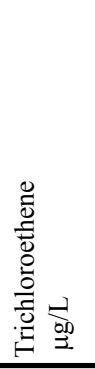 & 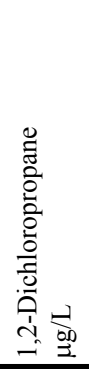 \\
\hline $\begin{array}{l}\text { Detection } \\
\text { limit }\end{array}$ & & 0.5 & 0.5 & 0.5 & 0.5 & 0.5 & 0.5 & 0.5 & 0.5 & 0.5 & 0.5 & 0.5 & 0.5 & 0.5 & 0.5 & 0.5 \\
\hline $\begin{array}{l}\text { MCL - } \\
\text { California } \\
\end{array}$ & & & & 0.5 & & & 150 & & 10 & 5 & & 200 & 0.5 & 0.5 & 5 & 5 \\
\hline $\begin{array}{l}\text { MCL - } \\
\text { Federal }\end{array}$ & & & & 2 & & & & 5 & 100 & & 100 & 200 & 5 & 5 & 5 & 5 \\
\hline Well ID & & & & & & & & & & & & & & & & \\
\hline NLF-6 & $6 / 29 / 11$ & $\mathrm{ND}$ & ND & $\mathrm{ND}$ & $\mathrm{ND}$ & $\mathrm{ND}$ & ND & ND & $\mathrm{ND}$ & $\mathrm{ND}$ & 0.75 & $\mathrm{ND}$ & 1.8 & ND & $\mathrm{ND}$ & $\mathrm{ND}$ \\
\hline Field Dup & $6 / 29 / 11$ & ND & ND & ND & ND & ND & ND & ND & ND & ND & 0.73 & ND & 1.8 & $\mathrm{ND}$ & ND & ND \\
\hline Field Blank & $6 / 29 / 11$ & $\mathrm{ND}$ & ND & $\mathrm{ND}$ & ND & ND & ND & ND & ND & $\mathrm{ND}$ & ND & ND & $\mathrm{ND}$ & $\mathrm{ND}$ & ND & ND \\
\hline AS-3A & $6 / 29 / 11$ & $\mathrm{ND}$ & ND & $\mathrm{ND}$ & ND & ND & $\mathrm{ND}$ & ND & ND & $\mathrm{ND}$ & ND & ND & $\mathrm{ND}$ & ND & ND & $\mathrm{ND}$ \\
\hline AS-3B & $6 / 29 / 11$ & $\mathrm{ND}$ & $\mathrm{ND}$ & $\mathrm{ND}$ & $\mathrm{ND}$ & ND & ND & ND & $\mathrm{ND}$ & $\mathrm{ND}$ & ND & $\mathrm{ND}$ & ND & ND & ND & $\mathrm{ND}$ \\
\hline AS-3C & $6 / 29 / 11$ & ND & ND & ND & ND & ND & ND & ND & ND & ND & ND & ND & ND & ND & ND & ND \\
\hline FM-1R & $9 / 6 / 11$ & - & - & - & - & - & - & - & - & - & - & - & - & - & - & - \\
\hline FM-7R & $9 / 6 / 11$ & - & - & - & - & - & - & - & - & - & - & - & - & - & - & - \\
\hline AS-4 & $6 / 29 / 11$ & $\mathrm{ND}$ & $\mathrm{ND}$ & $\mathrm{ND}$ & $\mathrm{ND}$ & $\mathrm{ND}$ & $\mathrm{ND}$ & $\mathrm{ND}$ & $\mathrm{ND}$ & $\mathrm{ND}$ & $\mathrm{ND}$ & $\mathrm{ND}$ & $\mathrm{ND}$ & ND & ND & $\mathrm{ND}$ \\
\hline Trip Blank & $6 / 29 / 11$ & $\mathrm{ND}$ & $\mathrm{ND}$ & $\mathrm{ND}$ & $\mathrm{ND}$ & $\mathrm{ND}$ & $\mathrm{ND}$ & $\mathrm{ND}$ & $\mathrm{ND}$ & $\mathrm{ND}$ & $\mathrm{ND}$ & $\mathrm{ND}$ & $\mathrm{ND}$ & ND & $\mathrm{ND}$ & $\mathrm{ND}$ \\
\hline
\end{tabular}


Table 9-1 Results of Groundwater Analyses at SNL/CA, 2011 (continued)

\begin{tabular}{|c|c|c|c|c|c|c|c|c|c|c|c|c|c|c|}
\hline & Date & 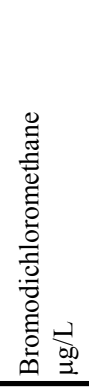 & 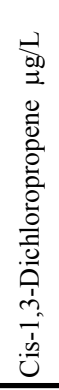 & 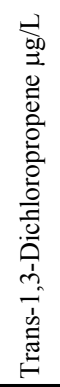 & 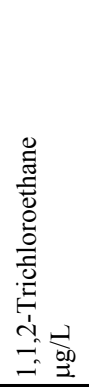 & 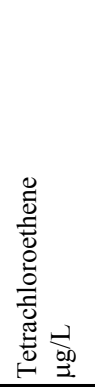 & 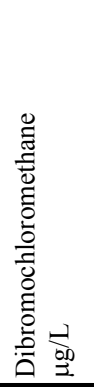 & 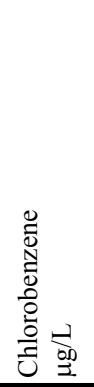 & 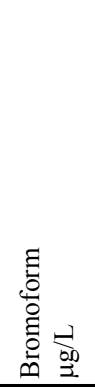 & 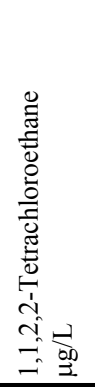 & 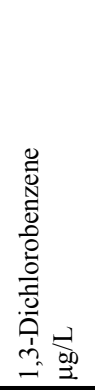 & 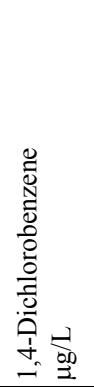 & 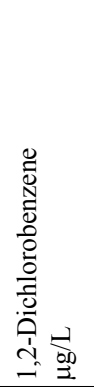 & 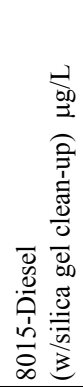 \\
\hline $\begin{array}{l}\text { Detection } \\
\text { limit }\end{array}$ & & 0.5 & 0.5 & 0.5 & 0.5 & 0.5 & 0.5 & 0.5 & 0.5 & 0.5 & 0.5 & 0.5 & 0.5 & 50 \\
\hline $\begin{array}{l}\text { MCL - } \\
\text { California } \\
\end{array}$ & & & 0.5 & & 32 & 5 & & 30 & & 1 & & 5 & & \\
\hline $\begin{array}{l}\text { MCL - } \\
\text { Federal }\end{array}$ & & 100 & & & 5 & 5 & 100 & 100 & 100 & & 600 & 75 & 600 & \\
\hline Well ID & & & & & & & & & & & & & & \\
\hline NLF-6 & $6 / 29 / 11$ & ND & ND & ND & ND & ND & ND & ND & ND & ND & ND & ND & ND & ND \\
\hline Field dup & $6 / 29 / 11$ & ND & ND & ND & ND & ND & $\mathrm{ND}$ & $\mathrm{ND}$ & ND & ND & ND & ND & ND & ND \\
\hline Field blank & $6 / 29 / 11$ & ND & ND & ND & ND & ND & ND & ND & ND & ND & ND & ND & ND & ND \\
\hline AS-3A & $6 / 29 / 11$ & ND & ND & ND & $\mathrm{ND}$ & ND & ND & $\mathrm{ND}$ & ND & $\mathrm{ND}$ & $\mathrm{ND}$ & ND & ND & ND \\
\hline AS-3B & $6 / 29 / 11$ & ND & ND & ND & ND & ND & ND & ND & ND & ND & ND & ND & ND & ND \\
\hline AS-3C & $6 / 29 / 11$ & ND & ND & ND & ND & ND & ND & ND & ND & ND & $\mathrm{ND}$ & ND & $\mathrm{ND}$ & ND \\
\hline FM-1R & $9 / 6 / 11$ & - & - & - & - & - & - & - & - & - & - & - & - & 210 \\
\hline FM-7 R & $9 / 6 / 11$ & - & - & - & - & - & - & - & - & - & - & - & - & ND \\
\hline AS-4 & $6 / 29 / 11$ & ND & ND & ND & ND & ND & ND & ND & ND & ND & ND & ND & ND & ND \\
\hline Trip Blank & $6 / 29 / 11$ & ND & ND & ND & ND & ND & ND & ND & ND & ND & ND & ND & ND & ND \\
\hline
\end{tabular}

MCL - Maximum contaminant level.

ND - Non-detectable.

-- Not required to analyze or sample not collected. 
Table 9-1 Results of Groundwater Analyses at SNL/CA, 2011 (continued)

\begin{tabular}{|c|c|c|c|c|c|c|c|c|c|c|c|c|c|c|c|c|c|c|c|}
\hline & Date & 豆 & 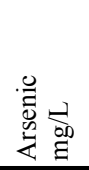 & 咅 & 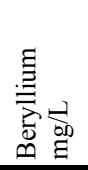 & 志 & 咅 & 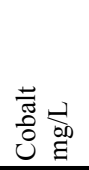 & $\begin{array}{l}\dot{\bar{o}} \\
\overline{\tilde{z}} \\
\bar{\delta}\end{array}$ & 芯 & 鹿 & 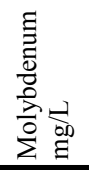 & 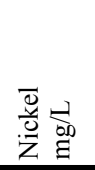 & 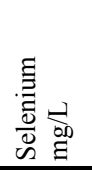 & 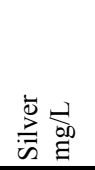 & 声 & 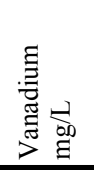 & 害茄 & 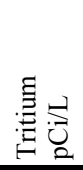 \\
\hline $\begin{array}{l}\text { Detection } \\
\text { limit } \\
\end{array}$ & & 0.0005 & 0.0005 & 0.005 & 0.0005 & 0.00025 & 0.0005 & 0.0005 & 0.0005 & 0.0005 & 0.000012 & 0.0005 & 0.0005 & 0.0005 & 0.00019 & 0.0005 & 0.0005 & 0.005 & 210 \\
\hline $\begin{array}{l}\text { MCL - } \\
\text { California }\end{array}$ & & & 0.01 & 1 & & 0.01 & 0.05 & & $1^{\mathrm{d}}$ & 0.05 & 0.002 & & & 0.01 & 0.05 & & & $5^{\mathrm{d}}$ & 20000 \\
\hline $\begin{array}{l}\text { MCL - } \\
\text { Federal } \\
\text { Well ID }\end{array}$ & & 0.006 & 0.01 & 2 & 0.004 & 0.005 & 0.1 & & $1^{\mathrm{d}}$ & & 0.002 & & 0.1 & 0.05 & $0.1^{\mathrm{d}}$ & 0.002 & & $5^{\mathrm{d}}$ & \\
\hline NLF-6 & $6 / 29 / 11$ & - & -- & -- & -- & -- & -- & -- & -- & -- & -- & -- & -- & -- & -- & -- & -- & -- & -- \\
\hline Field dup & $6 / 29 / 11$ & -- & -- & -- & -- & -- & -- & -- & -- & -- & -- & -- & -- & -- & -- & -- & -- & -- & -- \\
\hline Field blank & $6 / 29 / 11$ & -- & -- & -- & -- & -- & -- & -- & -- & -- & -- & -- & -- & -- & -- & -- & -- & -- & -- \\
\hline AS-3A & $6 / 29 / 11$ & 0.00057 & 0.00087 & 0.11 & $\mathrm{ND}$ & $\mathrm{ND}$ & 0.0085 & $\mathrm{ND}$ & 0.0012 & 0.0010 & 0.00010 & 0.0029 & 0.00091 & ND & $\mathrm{ND}$ & $\mathrm{ND}$ & 0.0022 & 0.0073 & $<240$ \\
\hline AS-3B & $6 / 29 / 11$ & ND & 0.00075 & 0.12 & $\mathrm{ND}$ & $\mathrm{ND}$ & 0.0078 & $\mathrm{ND}$ & 0.0017 & ND & 0.000050 & 0.0032 & ND & 0.00051 & $\mathrm{ND}$ & $\mathrm{ND}$ & 0.0022 & 0.0058 & $<230$ \\
\hline AS-3C & $6 / 29 / 11$ & 0.00060 & 0.0010 & 0.12 & $\mathrm{ND}$ & $\mathrm{ND}$ & 0.0073 & ND & 0.0017 & 0.0011 & 0.000053 & 0.0030 & $\mathrm{ND}$ & 0.00060 & $\mathrm{ND}$ & ND & 0.0023 & 0.0094 & $<240$ \\
\hline FM-1R & 9/6/11 & -- & -- & -- & -- & -- & -- & -- & -- & -- & -- & -- & -- & -- & -- & -- & -- & -- & -- \\
\hline FM-7 R & $9 / 6 / 11$ & -- & -- & -- & -- & -- & -- & -- & -- & -- & -- & -- & -- & -- & -- & -- & -- & -- & -- \\
\hline AS-4 & $6 / 29 / 11$ & $\mathrm{ND}$ & 0.0010 & 0.052 & $\mathrm{ND}$ & $\mathrm{ND}$ & 0.00059 & $\mathrm{ND}$ & 0.0011 & $\mathrm{ND}$ & $\mathrm{ND}$ & 0.0017 & $\mathrm{ND}$ & $\mathrm{ND}$ & ND & $\mathrm{ND}$ & 0.0024 & 0.0060 & $<240$ \\
\hline
\end{tabular}


Table 9-2 Well Depth and Screen Period Interval

\begin{tabular}{|c|c|c|c|}
\hline Area & Well ID & Well Depth (ft) & Screen Period Interval (ft) \\
\hline \multirow[t]{2}{*}{ Fuel Oil Spill Site } & FM-1R & 129 & $99-129$ \\
\hline & FM-7R & 129 & $99-129$ \\
\hline \multirow[t]{4}{*}{ Arroyo Seco } & $\mathrm{AS}-3 \mathrm{~A}$ & 112.58 & $100-110$ \\
\hline & $\mathrm{AS}-3 \mathrm{~B}$ & 124.97 & $118-123$ \\
\hline & AS-3C & 157 & $150-155$ \\
\hline & AS-4 & 28.57 & $15-25$ \\
\hline Trudell Auto Repair Shop & MW-406 & 94 & $87^{\mathrm{a}}$ \\
\hline Navy Landfill & NLF-6 & 110 & $87-102$ \\
\hline
\end{tabular}

${ }^{\text {a }}$ Start of screen interval. Length of screen interval is unknown. 


\begin{tabular}{|c|c|c|c|c|c|c|c|}
\hline & & $\underset{\text { SM5210B }}{\text { BOD }^{c}}$ & $\begin{array}{c}\mathrm{COD}^{c} \\
(\mathrm{mg} / \mathrm{L}) \\
\mathbf{E} 410.4\end{array}$ & $\begin{array}{c}\mathbf{T D S}^{c} \\
(\mathrm{mg} / \mathrm{L}) \\
\text { SM2540C }\end{array}$ & $\begin{array}{c}\mathrm{TSS}^{c} \\
(\mathrm{mg} / \mathrm{L}) \\
\text { SM2540D }\end{array}$ & $\begin{array}{c}\text { Oil \& } \\
\text { Grease } \\
(\mathrm{mg} / \mathrm{L})^{d} \\
\end{array}$ & $\underset{(\mathrm{mg} / \mathrm{L})}{\text { Kelada-01 }^{d}}$ \\
\hline Date & $\begin{array}{l}\text { Laboratory } \\
\text { ID \#a }\end{array}$ & \multicolumn{6}{|c|}{ All results reported in $\mathrm{mg} / \mathrm{L}$} \\
\hline \multicolumn{8}{|l|}{ January } \\
\hline January 4 & 1101051 & 430 & 780 & 279 & 845 & $f$ & 0.014 \\
\hline \multicolumn{8}{|l|}{ February } \\
\hline February 1 & 1102030 & 240 & 320 & 309 & 356 & $f$ & 0.019 \\
\hline \multicolumn{8}{|l|}{ March } \\
\hline March 1 & 1103033 & 110 & 240 & 232 & 107 & $f$ & 0.012 \\
\hline \multicolumn{8}{|l|}{ April } \\
\hline April 5 & 1104090 & 250 & 280 & 232 & 340 & $f$ & 0.011 \\
\hline \multicolumn{8}{|l|}{ May } \\
\hline May 3 & 1105074 & 270 & 380 & 288 & 762 & $f$ & 0.016 \\
\hline \multicolumn{8}{|l|}{ June } \\
\hline June 7 & 1106246 & 200 & 450 & 299 & 272 & $f$ & 0.014 \\
\hline \multicolumn{8}{|l|}{ July } \\
\hline July 5 & 1107078 & 240 & 640 & 234 & 306 & $f$ & 0.015 \\
\hline \multicolumn{8}{|l|}{ August } \\
\hline August 2 & 1108060 & 280 & 690 & 299 & 392 & $f$ & 0.016 \\
\hline \multicolumn{8}{|l|}{ September } \\
\hline September 6 & 1109098 & 110 & 1200 & 362 & 428 & $f$ & 0.009 \\
\hline \multicolumn{8}{|l|}{ October } \\
\hline October 4 & 1110077 & 100 & 600 & 296 & 376 & $f$ & 0.014 \\
\hline \multicolumn{8}{|l|}{ November } \\
\hline November 1 & 1111045 & 260 & 690 & 265 & 272 & $f$ & 0.016 \\
\hline \multicolumn{8}{|l|}{ December ${ }^{*}$} \\
\hline December 6 & 1112164 & 160 & 570 & 296 & 424 & $f$ & 0.010 \\
\hline $\begin{array}{c}\text { Discharge } \\
\text { Limit }^{b}\end{array}$ & & $\mathrm{~N} / \mathrm{A}^{e}$ & $\mathrm{~N} / \mathrm{A}^{e}$ & $\mathrm{~N} / \mathrm{A}^{e}$ & $\mathrm{~N} / \mathrm{A}^{e}$ & 100 & 0.04 \\
\hline \multicolumn{8}{|c|}{$\begin{array}{l}a \text { Analyses performed by an off-site, state certified laboratory. } \\
b_{\text {Discharge concentration limits, City of Livermore Municipal Code } 13.32 .}\end{array}$} \\
\hline \multicolumn{8}{|c|}{$\begin{array}{l}{ }^{c} \text { Weekly composite sample. The dates indicate the day the sample was collected. The sample represents a representative composite for th } \\
\text { previous week. } \\
{ }^{d} \text { Grab sample. }\end{array}$} \\
\hline
\end{tabular}


Table 9-4 Routine Monitoring Results for SNL/CA Sanitary Sewer Outfall, Method E200.8, 2011

\begin{tabular}{|c|c|c|c|c|c|c|c|c|c|c|}
\hline & & As & Cd & $\mathrm{Cr}$ & $\mathbf{C u}$ & $\mathbf{P b}$ & $\mathrm{Hg}$ & $\mathbf{N i}$ & Ag & $\mathbf{Z n}$ \\
\hline Date $^{a}$ & Laboratory ID \# & \multicolumn{9}{|c|}{ All results reported in $\mathrm{mg} / \mathrm{L}$} \\
\hline \multicolumn{11}{|l|}{ January } \\
\hline January 11 & $1101222-001 \mathrm{~A}$ & $\begin{array}{l}0.001 \\
7\end{array}$ & $\begin{array}{l}0.000 \\
73\end{array}$ & 0.0069 & 0.28 & 0.0056 & 0.00031 & 0.0064 & 0.00087 & 0.46 \\
\hline January 25 & $1101587-001 \mathrm{~A}$ & $\begin{array}{l}0.001 \\
9\end{array}$ & $\begin{array}{l}0.000 \\
72\end{array}$ & 0.0079 & 0.27 & 0.0085 & 0.00034 & 0.0069 & 0.00096 & 0.53 \\
\hline \multicolumn{11}{|l|}{ February } \\
\hline February 1 & $1102030-001 \mathrm{~A}$ & $\begin{array}{l}0.001 \\
4\end{array}$ & $\begin{array}{l}0.000 \\
50\end{array}$ & 0.0037 & 0.19 & 0.0046 & 0.00012 & 0.0050 & 0.00042 & 0.33 \\
\hline February 8 & $1102230-001 \mathrm{~A}$ & $\begin{array}{l}0.001 \\
4\end{array}$ & $\begin{array}{l}0.000 \\
41\end{array}$ & 0.0040 & 0.15 & 0.0034 & 0.000086 & 0.0036 & 0.00037 & 1.0 \\
\hline February 15 & $1102439-001 \mathrm{~A}$ & $\begin{array}{l}0.001 \\
6\end{array}$ & $\begin{array}{l}0.001 \\
5\end{array}$ & 0.0065 & 0.30 & 0.0077 & 0.00016 & 0.0057 & 0.0026 & 0.50 \\
\hline February 22 & $1102683-001 \mathrm{~A}$ & $\begin{array}{l}0.001 \\
4\end{array}$ & $\begin{array}{l}0.000 \\
58\end{array}$ & 0.0045 & 0.40 & 0.0034 & 0.000076 & 0.0048 & 0.00037 & 1.3 \\
\hline \multicolumn{11}{|l|}{ March } \\
\hline March 1 & $1103033-001 \mathrm{~A}$ & $\begin{array}{l}0.001 \\
3\end{array}$ & $\begin{array}{l}0.000 \\
57\end{array}$ & 0.0036 & 0.22 & 0.0032 & 0.00012 & 0.0048 & 0.00074 & 0.32 \\
\hline March 8 & $1103265-001 \mathrm{~A}$ & $\begin{array}{l}0.001 \\
3\end{array}$ & $\begin{array}{l}0.000 \\
77\end{array}$ & 0.0020 & 0.10 & 0.0032 & 0.000056 & 0.0036 & 0.0011 & 0.30 \\
\hline March 15 & $1103496-001 \mathrm{~A}$ & $\begin{array}{l}0.001 \\
3\end{array}$ & $\begin{array}{l}0.000 \\
52\end{array}$ & 0.0097 & 0.20 & 0.0030 & 0.000077 & 0.0057 & 0.00055 & 0.35 \\
\hline March 22 & $1103729-001 \mathrm{~A}$ & $\begin{array}{l}0.001 \\
7\end{array}$ & $\begin{array}{l}0.000 \\
45\end{array}$ & 0.0046 & 0.14 & 0.0027 & 0.000085 & 0.0056 & 0.00043 & 0.27 \\
\hline
\end{tabular}




\begin{tabular}{|c|c|c|c|c|c|c|c|c|c|c|}
\hline March 29 & 1103991-001A & $\begin{array}{l}0.001 \\
8\end{array}$ & $\begin{array}{l}0.000 \\
59\end{array}$ & 0.0046 & 0.20 & 0.0031 & 0.00012 & 0.0060 & 0.0011 & 0.29 \\
\hline \multicolumn{11}{|l|}{ April } \\
\hline April 5 & $1104090-001 \mathrm{~A}$ & $\begin{array}{l}0.001 \\
4\end{array}$ & $\begin{array}{l}0.000 \\
51\end{array}$ & 0.0041 & 0.18 & 0.0026 & 0.00010 & 0.0052 & 0.00045 & 0.26 \\
\hline April 12 & 1104341-001A & $\begin{array}{l}0.001 \\
4\end{array}$ & $\begin{array}{l}0.000 \\
50\end{array}$ & 0.0037 & 0.23 & 0.0058 & 0.00010 & 0.0037 & 0.00046 & 1.0 \\
\hline April 19 & $1104542-001 \mathrm{~A}$ & $\begin{array}{l}0.001 \\
6\end{array}$ & $\begin{array}{l}0.000 \\
72\end{array}$ & 0.0093 & 0.20 & 0.0050 & 0.00012 & 0.0065 & 0.0012 & 1.1 \\
\hline April 26 & $1104742-001 \mathrm{~A}$ & $\begin{array}{l}0.001 \\
4\end{array}$ & $\begin{array}{l}0.000 \\
73\end{array}$ & 0.0056 & 0.25 & 0.0045 & 0.00018 & 0.0046 & 0.0016 & 0.32 \\
\hline
\end{tabular}


Table 9-4 Routine Monitoring Results for SNL/CA Sanitary Sewer Outfall, Method E200.8, 2011 (continued)

\begin{tabular}{|c|c|c|c|c|c|c|c|c|c|c|}
\hline & & As & Cd & $\mathrm{Cr}$ & $\mathrm{Cu}$ & $\mathbf{P b}$ & Hg & $\mathrm{Ni}$ & Ag & Zn \\
\hline Date $^{a}$ & 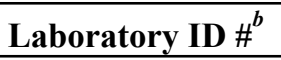 & \multicolumn{9}{|c|}{ All results reported in $\mathrm{mg} / \mathrm{L}$} \\
\hline \multicolumn{11}{|l|}{ May } \\
\hline May 3 & $1105074-001 \mathrm{~A}$ & $\begin{array}{l}0.001 \\
4\end{array}$ & $\begin{array}{l}0.000 \\
72\end{array}$ & 0.0028 & 0.27 & 0.0048 & 0.00016 & 0.0044 & 0.00060 & 0.32 \\
\hline May 10 & $1105277-001 \mathrm{~A}$ & $\begin{array}{l}0.001 \\
1\end{array}$ & $\begin{array}{l}0.000 \\
52\end{array}$ & 0.0040 & 0.24 & 0.0042 & 0.000096 & 0.0036 & 0.00056 & 1.0 \\
\hline May 17 & $1105485-001 \mathrm{~A}$ & $\begin{array}{l}0.001 \\
4\end{array}$ & $\begin{array}{l}0.000 \\
46\end{array}$ & 0.0030 & 0.19 & 0.0025 & 0.000068 & 0.0044 & 0.00062 & 0.47 \\
\hline May 24 & $1105723-001 \mathrm{~A}$ & $\begin{array}{l}0.001 \\
1\end{array}$ & $\begin{array}{l}0.000 \\
39\end{array}$ & 0.0018 & 0.20 & 0.0025 & 0.000063 & 0.0035 & 0.00053 & 0.19 \\
\hline \multicolumn{11}{|l|}{ June } \\
\hline June 7 & $1106246-001 \mathrm{~A}$ & $\begin{array}{l}0.001 \\
1\end{array}$ & $\begin{array}{l}0.000 \\
31\end{array}$ & 0.0012 & 0.23 & 0.0034 & 0.000043 & 0.0031 & 0.00039 & 0.21 \\
\hline June 14 & $1106453-001 \mathrm{~A}$ & $\begin{array}{l}0.001 \\
2\end{array}$ & $\begin{array}{l}0.000 \\
37\end{array}$ & 0.0012 & 0.11 & 0.0034 & 0.000032 & 0.0033 & $<0.00019$ & 0.18 \\
\hline June 21 & $1106698-001 \mathrm{~A}$ & $\begin{array}{l}0.002 \\
6\end{array}$ & $\begin{array}{l}0.000 \\
29\end{array}$ & 0.0011 & 0.21 & 0.0019 & 0.000054 & 0.0029 & 0.00028 & 0.21 \\
\hline June 28 & $1106922-001 \mathrm{~A}$ & $\begin{array}{l}0.002 \\
7\end{array}$ & $\begin{array}{l}0.000 \\
36\end{array}$ & 0.0015 & 0.22 & 0.0024 & 0.000043 & 0.0032 & 0.0012 & 0.18 \\
\hline June 7 & $1106246-001 \mathrm{~A}$ & $\begin{array}{l}0.001 \\
1\end{array}$ & $\begin{array}{l}0.000 \\
31\end{array}$ & 0.0012 & 0.23 & 0.0034 & 0.000043 & 0.0031 & 0.00039 & 0.21 \\
\hline \multicolumn{11}{|l|}{ July } \\
\hline July 5 & $1107078-001 \mathrm{~A}$ & $\begin{array}{l}0.002 \\
2\end{array}$ & $\begin{array}{l}0.000 \\
31\end{array}$ & 0.0011 & 0.17 & 0.0025 & 0.000039 & 0.0025 & 0.00026 & 0.16 \\
\hline July 12 & $1107274-001 \mathrm{~A}$ & $\begin{array}{l}0.002 \\
3\end{array}$ & $\begin{array}{l}0.000 \\
48\end{array}$ & 0.0020 & 0.22 & 0.0039 & 0.000063 & 0.0040 & 0.00074 & 0.22 \\
\hline July 19 & $1107504-001 \mathrm{~A}$ & $\begin{array}{l}0.001 \\
9\end{array}$ & $\begin{array}{l}0.000 \\
39\end{array}$ & 0.0037 & 0.25 & 0.0039 & 0.00031 & 0.0050 & 0.00082 & 0.25 \\
\hline
\end{tabular}




\begin{tabular}{|c|c|c|c|c|c|c|c|c|c|c|}
\hline July 26 & $1107721-001 \mathrm{~A}$ & $\begin{array}{l}0.002 \\
1\end{array}$ & $\begin{array}{l}0.000 \\
31\end{array}$ & 0.0027 & 0.18 & 0.0025 & 0.000041 & 0.0041 & 0.00039 & 0.16 \\
\hline \multicolumn{11}{|l|}{ August } \\
\hline August 2 & $1108060-001 \mathrm{~A}$ & 0.0019 & $\begin{array}{l}0.0003 \\
9\end{array}$ & 0.0015 & 0.16 & 0.0024 & 0.000048 & 0.0031 & 0.00053 & 0.20 \\
\hline August 9 & $1108278-001 \mathrm{~A}$ & 0.0016 & $\begin{array}{l}0.0003 \\
8\end{array}$ & 0.0027 & 0.17 & 0.0035 & 0.000058 & 0.0038 & 0.00064 & 0.22 \\
\hline August 16 & $1108499-001 \mathrm{~A}$ & $<0.0050$ & $<0.0025$ & $<0.0050$ & 0.31 & $<0.0050$ & $<0.00025$ & $<0.0050$ & $<0.0019$ & 0.34 \\
\hline August 23 & $1108691-001 \mathrm{~A}$ & 0.0017 & $\begin{array}{l}0.0003 \\
9\end{array}$ & 0.0010 & 0.15 & 0.0026 & 0.000042 & 0.0029 & 0.00031 & 0.18 \\
\hline August 30 & $1108879-001 \mathrm{~A}$ & $<0.0050$ & $<0.0025$ & $<0.0050$ & 0.19 & $<0.0050$ & $<0.00025$ & $<0.0050$ & $<0.0019$ & 0.25 \\
\hline
\end{tabular}


Table 9-4 Routine Monitoring Results for SNL/CA Sanitary Sewer Outfall, Method E200.8, 2011 (continued)

\begin{tabular}{|c|c|c|c|c|c|c|c|c|c|c|}
\hline & & As & Cd & $\mathrm{Cr}$ & $\mathbf{C u}$ & $\mathbf{P b}$ & $\mathrm{Hg}$ & Ni & Ag & Zn \\
\hline Date $^{a}$ & 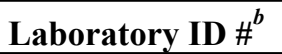 & \multicolumn{9}{|c|}{ All results reported in $\mathrm{mg} / \mathrm{L}$} \\
\hline \multicolumn{11}{|l|}{ September } \\
\hline September 6 & $1109098-001 \mathrm{~A}$ & $\begin{array}{l}0.00 \\
19\end{array}$ & $\begin{array}{l}0.0003 \\
4\end{array}$ & 0.0015 & 0.16 & 0.0016 & 0.000033 & 0.0029 & 0.00036 & 0.16 \\
\hline September 13 & $1109294-001 \mathrm{~A}$ & $\begin{array}{l}0.00 \\
13\end{array}$ & $\begin{array}{l}0.0002 \\
7\end{array}$ & 0.0015 & 0.13 & 0.0014 & 0.000031 & 0.0019 & 0.00020 & 0.13 \\
\hline September 20 & $1109504-001 \mathrm{~A}$ & $\begin{array}{l}0.00 \\
16\end{array}$ & $\begin{array}{l}0.0004 \\
7\end{array}$ & 0.0042 & 0.29 & 0.0046 & 0.00014 & 0.0047 & 0.0022 & 0.40 \\
\hline September 27 & $1109775-001 \mathrm{~A}$ & $\begin{array}{l}<0.00 \\
50\end{array}$ & $<0.0025$ & $<0.0050$ & 0.22 & $<0.0050$ & $<0.00025$ & 0.0058 & $<0.0019$ & 0.28 \\
\hline \multicolumn{11}{|l|}{ October } \\
\hline October 4 & $1110077-001 \mathrm{~A}$ & $\begin{array}{l}0.00 \\
21\end{array}$ & $\begin{array}{l}0.0003 \\
9\end{array}$ & 0.0015 & 0.17 & 0.0026 & 0.000036 & 0.0027 & 0.00050 & 0.19 \\
\hline October 11 & $1110345-001 \mathrm{~A}$ & $\begin{array}{l}<0.00 \\
50\end{array}$ & $<0.0025$ & $<0.0050$ & 0.16 & $<0.0050$ & $<0.00025$ & $<0.0050$ & $<0.0019$ & 0.23 \\
\hline October 25 & $1110758-001 \mathrm{~A}$ & $\begin{array}{c}<0.01 \\
0\end{array}$ & $<0.0050$ & $<0.010$ & 0.12 & $<0.010$ & $<0.00050$ & $<0.010$ & $<0.0038$ & 0.17 \\
\hline \multicolumn{11}{|l|}{ November } \\
\hline November 1 & $1111045-001 \mathrm{~A}$ & $\begin{array}{l}<0.00 \\
50\end{array}$ & $<0.0025$ & $<0.0050$ & 0.25 & $<0.0050$ & $<0.00025$ & $<0.0050$ & $<0.0019$ & 0.18 \\
\hline November 8 & $1111302-001 \mathrm{~A}$ & $\begin{array}{l}0.00 \\
23\end{array}$ & $\begin{array}{l}0.0005 \\
4\end{array}$ & 0.0028 & 0.22 & 0.0042 & 0.00010 & 0.0056 & 0.0012 & 0.25 \\
\hline November 15 & $1111504-001 \mathrm{~A}$ & $\begin{array}{l}0.00 \\
18\end{array}$ & $\begin{array}{l}0.0004 \\
7\end{array}$ & 0.0020 & 0.19 & 0.0026 & 0.000054 & 0.0042 & 0.00043 & 0.23 \\
\hline November 22 & $1111760-001 \mathrm{~A}$ & $\begin{array}{l}<0.00 \\
50\end{array}$ & $<0.0025$ & $<0.0050$ & 0.21 & $<0.0050$ & $<0.00025$ & $<0.0050$ & $<0.0019$ & 0.20 \\
\hline November 29 & $1111854-001 \mathrm{~A}$ & 0.00 & 0.0004 & 0.0019 & 0.26 & 0.0028 & 0.000051 & 0.0040 & 0.00066 & 0.19 \\
\hline
\end{tabular}




\begin{tabular}{|c|c|c|c|c|c|c|c|c|c|c|}
\hline & & 22 & 0 & & & & & & & \\
\hline \multicolumn{11}{|l|}{ December* } \\
\hline December 6 & $1112164-001 \mathrm{~A}$ & $\begin{array}{l}0.00 \\
21\end{array}$ & $\begin{array}{l}0.0003 \\
0\end{array}$ & $\begin{array}{l}0.0008 \\
7\end{array}$ & 0.14 & 0.0018 & 0.00011 & 0.0028 & 0.00031 & 0.15 \\
\hline December 13 & $1112402-001 \mathrm{~A}$ & $\begin{array}{l}0.00 \\
14\end{array}$ & $\begin{array}{l}<0.0002 \\
5\end{array}$ & 0.0016 & 0.17 & 0.0017 & 0.000048 & 0.0029 & $<0.00019$ & 0.13 \\
\hline December 20 & $1112587-001 \mathrm{~A}$ & $\begin{array}{l}0.00 \\
098\end{array}$ & $\begin{array}{l}<0.0002 \\
5\end{array}$ & 0.0013 & 0.15 & 0.0016 & 0.000063 & 0.0027 & $<0.00019$ & 0.17 \\
\hline December 27 & $1112733-001 \mathrm{~A}$ & $\begin{array}{l}0.00 \\
059\end{array}$ & $\begin{array}{l}<0.0002 \\
5\end{array}$ & $\begin{array}{l}0.0005 \\
6\end{array}$ & 0.10 & 0.0011 & 0.00011 & 0.0026 & 0.00067 & 0.091 \\
\hline \multicolumn{11}{|l|}{ Discharge } \\
\hline
\end{tabular}


Table 9-5 Routine Monitoring Results for SNL/CA Sanitary Sewer Outfall, 2011

\begin{tabular}{|c|c|c|c|}
\hline Date & $\begin{array}{c}\text { EPA Method } 624 \\
\text { Purgeable Priority Pollutants } \\
(\mu \mathrm{g} / \mathrm{L})\end{array}$ & $\begin{array}{c}\text { EPA Method } 625 \\
\text { Extractable Priority } \\
\text { Pollutants }(\mu \mathrm{g} / \mathrm{L}) \\
\end{array}$ & $\begin{array}{c}\text { EPA Method 608 } \\
\text { Organochlorine Pesticides } \\
(\mu \mathrm{g} / \mathrm{L})\end{array}$ \\
\hline January 4 & $\begin{array}{l}\text { Chloroform }-10 \\
\text { Bromoform }-0.62 \\
\text { Toluene }-1.2 \\
1,1,1 \text {-Trichlorethane }-0.99\end{array}$ & None & None \\
\hline February 2 & $\begin{array}{l}\text { Chloroform }-7.3 \\
\text { Bromoform }-0.72 \\
\end{array}$ & None & None \\
\hline March 2 & $\begin{array}{l}\text { Chloroform }-10 \\
\text { Bromoform }-1.4 \\
\text { toluene }-3.1 \\
\text { Bromodichloromethane }-0.74\end{array}$ & None & None \\
\hline April 5 & $\begin{array}{l}\text { Chloroform }-7.3 \\
\text { Bromoform }-1.2 \\
\end{array}$ & None & None \\
\hline May 3 & $\begin{array}{l}\text { Chloroform }-7.3 \\
\text { Bromoform }-1.3 \\
\text { Bromodichloromethane }-0.61\end{array}$ & None & None \\
\hline June 7 & $\begin{array}{l}\text { Chloroform }-6.7 \\
\text { Bromoform }-0.98\end{array}$ & None & p,p-DDT - 1.6 \\
\hline July 5 & $\begin{array}{l}\text { Chloroform }-5.8 \\
\text { Bromoform }-1.9 \\
\end{array}$ & None & None \\
\hline August 2 & Chloroform -4.5 & None & None \\
\hline September 6 & $\begin{array}{l}\text { Chloroform }-2.2 \\
\text { Bromoform }-1.3 \\
\end{array}$ & None & None \\
\hline October 4 & $\begin{array}{l}\text { Chloroform }-2.7 \\
\text { Bromoform }-0.92 \\
\text { Toluene }-1.6\end{array}$ & None & None \\
\hline November 1 & Chloroform - 3.6 & None & None \\
\hline December 6 & $\begin{array}{l}\text { Chloroform }-4.8 \\
\text { Bromoform }-0.94 \\
\text { Toluene }-0.85 \\
\text { Dibromochloromethane }-0.55\end{array}$ & None & None \\
\hline
\end{tabular}

This table reports all positively identified organic constituents designated as total toxic organics (TTO) by the United States Environmental Protection Agency. All other compounds comprising the EPA toxic organic list were below minimum detection limits, and therefore were not listed. The toxic organic discharge limit for SNL/CA is $1000 \mu \mathrm{g} / \mathrm{L}$. The total toxic organic number is derived by summing up all organic constituents greater than $10 \mu \mathrm{g} / \mathrm{L}$. Also, note that Chloroform is reported in this table although it is a common constituent of chlorinated water. 


\section{Distribution List}

\section{U.S. Department of Energy}

Karen Agogino (14)

U.S. Department of Energy

Sandia Site Office

P.O. Box 5400, MS 0184

Albuquerque, NM 87185-5400

Jeff Irwin (MS 9956) (CD only)

U.S. Department of Energy

DOE Facility Representative

Sandia National Laboratories, California

Steve Black

U.S. Department of Energy

NNSA Albuquerque Complex

P.O. Box 5400

Albuquerque, NM 87185-5400

Randal S. Scott

U.S. Department of Energy

National Nuclear Security Administration

Director of Environmental Operations

NA-173/ Germantown Bldg (B-125/GTN)

1000 Independence Ave, S.W.

Washington, D.C. 20585-1290

Ross Natoli (CD only)

U.S. Department of Energy

Office of Analysis

HS-24/Forrestal Bldg

1000 Independence Ave, S.W.

Washington, D.C. 20585

Glenn Podonsky

U.S. Department of Energy

Chief Health, Safety, and Security Officer

HS-1/Forrestal Bldg

1000 Independence Ave, S.W.

Washington, D.C. 20585
Andrew C. Lawrence

U.S. Department of Energy

Director, Office of Environmental Protection

Sustainability

HS-20 / Forrestal Bldg

1000 Independence Ave, S.W.

Washington, D.C. 20585-1290

Theresa Davis

Argonne National Laboratory

9700 S. Cass Avenue

Argonne, IL 60439

Joanne Duncan

Pacific Northwest National Laboratories

P.O. Box 999

Richland, WA 99352

Cheryl Voloshin

Lawrence Berkeley National Laboratory

One Cyclotron Road

Berkeley, CA 94720

Jean Dewart

Los Alamos National Laboratory

P.O. Box 1663

Los Alamos, NM 87545

Joan Hughes

Oak Ridge National Laboratory

P.O. Box 2008

Oak Ridge, TN 37831

Sharon Thompson

Oak Ridge National Laboratory

P.O. Box 2008

Oak Ridge, TN 37831

Al Mamatey

Savannah River Site

Savannah River Nuclear Solutions, LLC

Regulatory Integration \& Environmental

Services Department

Aiken, SC 29808 
Eric Mieland

Fermilab

P.O. Box 500

Batavia, IL 60510

Gretchen Gallegos

Lawrence Livermore National Laboratory

7000 East Avenue

Livermore, CA 94550

Karen Ratel

Brookhaven National Laboratory

P.O. Box 5000

Upton, NY 11973-5000

Cathy Wills

U.S. Department of Energy

Nevada Site Office

P.O. Box 98518

Las Vegas, NV 89193-8518

Marilyn Case

Idaho National Laboratory

2525 Fremont Avenue

Idaho Falls, ID 83415

LLNL Public Information Office (L-790)

Lawrence Livermore National Laboratory

7000 East Avenue

Livermore, CA 94550

\section{Other Federal Agencies}

Ann McPherson

U.S. Environmental Protection Agency

Region IX, CED-2

75 Hawthorne Street

San Francisco, CA 94105

Congressman John Garamendi

U.S. House of Representatives

California $10^{\text {th }}$ District

1981 N. California, Suite 220

Walnut Creek, CA 94596

Congressman John Garamendi

U.S. House of Representatives

California $10^{\text {th }}$ District

228 Canon House Building

Washington DC 20515

\section{State and Local Agencies}

Agnes Farres

Regional Water Quality Control Board

San Francisco Bay Region

1515 Clay Street, Suite 1400

Oakland, CA 94612

Alec Naugle

Regional Water Quality Control Board

San Francisco Bay Region

1515 Clay Street, Suite 1400

Oakland, CA 94612

Steve Aguiar

Livermore Water Reclamation Plant

101 West Jack London Boulevard

Livermore, CA 94550

Darren Greenwood

Assistant Public Works Director

City of Livermore

1052 S. Livermore Avenue

Livermore, CA 94550

Kelly Wee

Director of Compliance and Enforcement

Bay Area Air Quality Management District

939 Ellis Street

San Francisco, CA 94109

Cherry Padilla

California Environmental Protection Agency

Department of Toxic Substances Control

Region 2, Facility Permitting Branch

700 Heinz Avenue, Suite 200

Berkeley, CA 94710

Danielle Stefani

Livermore-Pleasanton Fire Department

3560 Nevada Street

Pleasanton, CA 94566

Joe Seto

Alameda County Flood Control and Water

Conservation District, Zone 7

100 North Canyons Parkway

Livermore, CA 94551 
Dan McIntyre

Director, Public Works

City of Livermore

1052 S. Livermore Avenue

Livermore, CA 94550

Linda Barton

City Manager

City of Livermore

1052 S. Livermore Avenue

Livermore, CA 94550

Assemblymember Joan Buchanan

California State Assembly

$15^{\text {th }}$ District

State Capitol

P.O. Box 942849

Sacramento, CA 94249-0015

Assemblymember Joan Buchanan

California State Assembly

$15^{\text {th }}$ District

2694 Bishop Drive, Ste 275

San Ramon, CA 94583

Supervisor Scott Haggerty

Supervisor District 1

Alameda County Board of Supervisors

1221 Oak Street, Suite 536

Oakland, CA 94612

The Honorable John Marchand

Mayor of Livermore

1052 S. Livermore Avenue

Livermore CA 94550

Senator Loni Hancock

California State Senate

$9^{\text {th }}$ District

State Capitol, Room 2082

Sacramento, CA 94248-0001

Senator Loni Hancock

California State Senate

$9^{\text {th }}$ District

1515 Clay Street, Ste 2202

Oakland, CA 94612

\section{Individuals and Organizations}

Mike and Ann Mueller

2693 South Vasco Road

Livermore, CA 94550

Marylia Kelley

Tri-Valley CAREs

2528 Old First Street

Livermore, CA 94550

\section{Sandia National Laboratories}

$\begin{array}{ll}\text { MS 0101 } & \text { P. Hommert, 1 } \\ \text { MS 9001 } & \text { R. Stulen, 8000 } \\ \text { MS 9114 } & \text { M.E. Janes, 8529 } \\ \text { MS 9902 } & \text { B. Larsen, 8516 (10) } \\ \text { MS 0899 } & \text { RIM - Reports (electronic } \\ & \text { copy) } \\ \text { MS 9021 } & \text { Classification Office, 8511 } \\ \text { MS 9021 } & \text { Classification Office, 8511 } \\ & \text { For DOE/OSTI }\end{array}$

\section{Internal Notification Only with Web Link}
MS 9004
P. Davies, 8100
MS 9153
MS 9054
MS 9293
MS 9405
MS 9151
MS 9956
MS 9902
MS 9902
MS 9902
MS 9902
MS 9902
MS 9902
MS 9956
MS 9956
MS 9293
MS 0725
MS 0725
MS 0141
MS 0141
MS 1151
MS 0728
MS 0730
MS 9290
R. Miller, 8200
R. Carling, 8300
D. Koker, 8500
G. Kubiak, 8600
L. Napolitano, 8900
J.R. Garcia, 8510
G. Shamber, 8516
R. Holland, 8516
L. Gardizi, 8516
J. Harris, 8516
M. Brynildson, 8516
L. Tidwell, 8516
A. Jackson, 8537
T.B. Garcia, 8516
D. Beyer, 8537
S. Gutierrez, 4100
F. Nimick, 4130
B. Krauss, 11000
A. Blumberg, 11100
J.F. Jarry, 4144
T.W. Cooper, 4140
S. Salinas, 4143
D. Powers, 8539 
